Prepared in cooperation with the National Park Service

\title{
Geologic Framework of Thermal Springs, Black Canyon, Nevada and Arizona
}

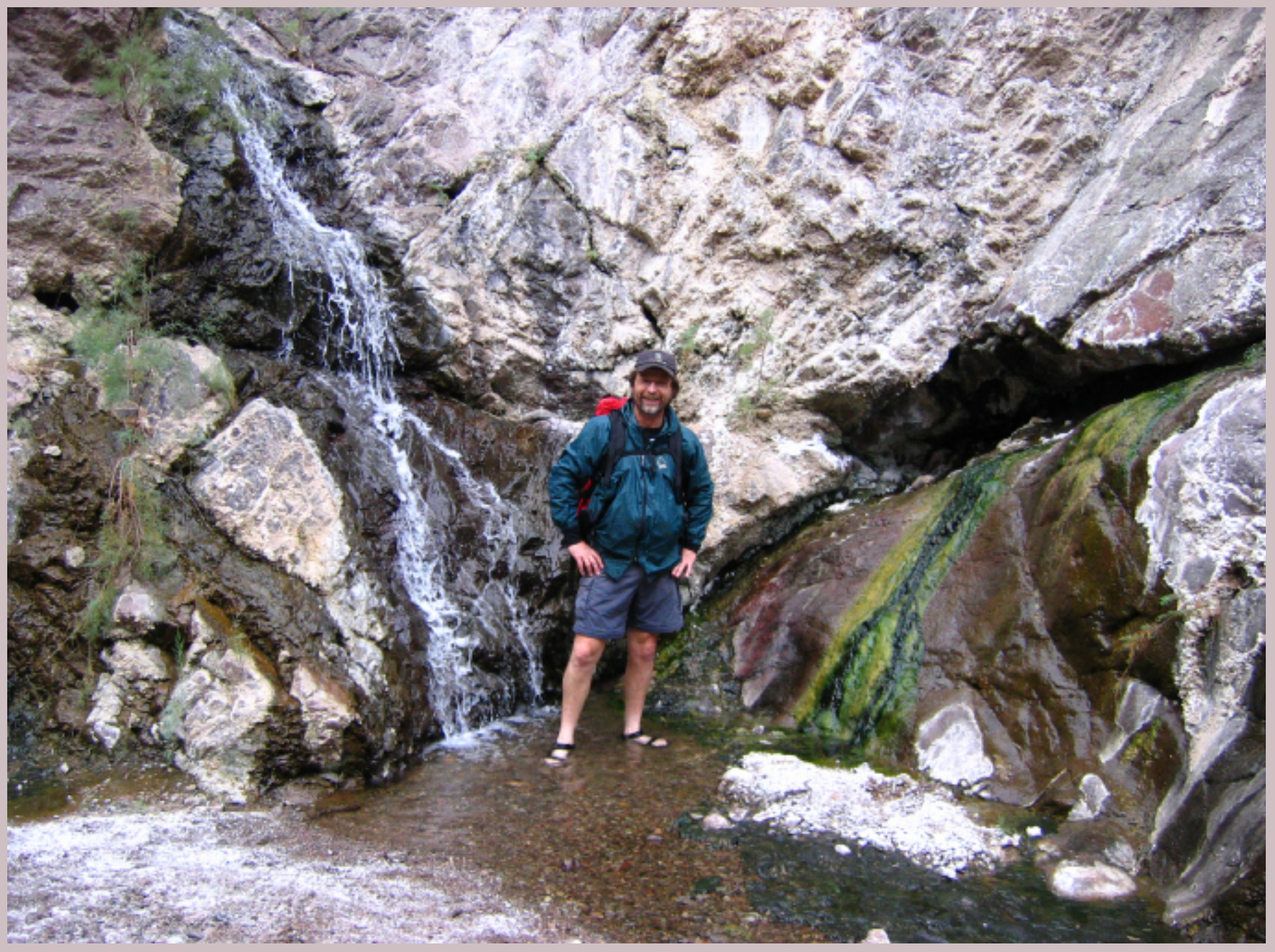

Open-File Report 2013-1267-B 
FRONT COVER

Photograph of William Van Liew, National Park Service hydrologist, in Boy Scout Canyon. Left foot is in a pool of thermal water discharging from a fracture in the Boulder City pluton. Right foot is in cold water resulting from cooling of thermal water in a water fall descending from a discharge site about $60 \mathrm{~m}$ above the canyon floor. 


\title{
Geologic Framework of Thermal Springs, Black Canyon, Nevada and Arizona
}

\author{
By L. Sue Beard, Zachary W. Anderson, Tracey J. Felger, and Gustav B. Seixas
}

Prepared in cooperation with the National Park Service

Open-File Report 2013-1267-B 


\section{U.S. Department of the Interior SALLY JEWELL, Secretary}

\section{U.S. Geological Survey Suzette M. Kimball, Acting Director}

\section{U.S. Geological Survey, Reston, Virginia: 2014}

For product and ordering information: World Wide Web: http://www.usgs.gov/pubprod Telephone: 1-888-ASK-USGS

For more information on the USGS - the Federal source for science about the Earth, its natural and living resources, natural hazards, and the environment: World Wide Web: http://www.usgs.gov

Telephone: 1-888-ASK-USGS

Any use of trade, firm, or product names is for descriptive purposes only and does not imply endorsement by the U.S. Government.

Although this information product, for the most part, is in the public domain, it also may contain copyrighted materials as noted in the text. Permission to reproduce copyrighted items must be secured from the copyright owner.

Part or all of this report is presented is Portable Document Format (PDF). For best results viewing and printing PDF documents, it is recommended that you download the documents to your computer and open them with Adobe Reader. PDF documents opened from your browser may not display or print as intended. Download the latest version of Adobe Reader, free of charge.

Suggested citation:

Beard, L.S., Anderson, Z.W., Felger, T.J., and Seixas, G.B., 2014, Geologic framework of thermal springs, Black Canyon, Nevada and Arizona: U.S. Geological Survey Open-File Report 2013-1267-B, 65 p., http://dx.doi.org/10.3133/ofr20141267B. 


\section{Acknowledgments}

We would like to thank the reviewers, Ric Page and Ernie Anderson, for their invaluable critiques of this report. Gene Smith, Rachael Johnson, and Denise Honn at University of Nevada Las Vegas helped immensely in understanding the regional volcanic stratigraphy and in cross-section construction through the River Mountains. In addition, we thank USGS colleagues Jim Paces, Leigh Justet, and Margot Truini for their expertise in water chemistry and Jon Wilson on hydrogeologic aspects of the study. Bill van Liew, Tom Culhane, and Gary Karst of the National Park Service provided guidance and excellent feedback, and shared their immense passion for all things water. Finally, we thank Kent Turner, Brian Wilson, and Mark Sappington at Lake Mead National Recreation Area for both science and logistical support.

\section{Contents}

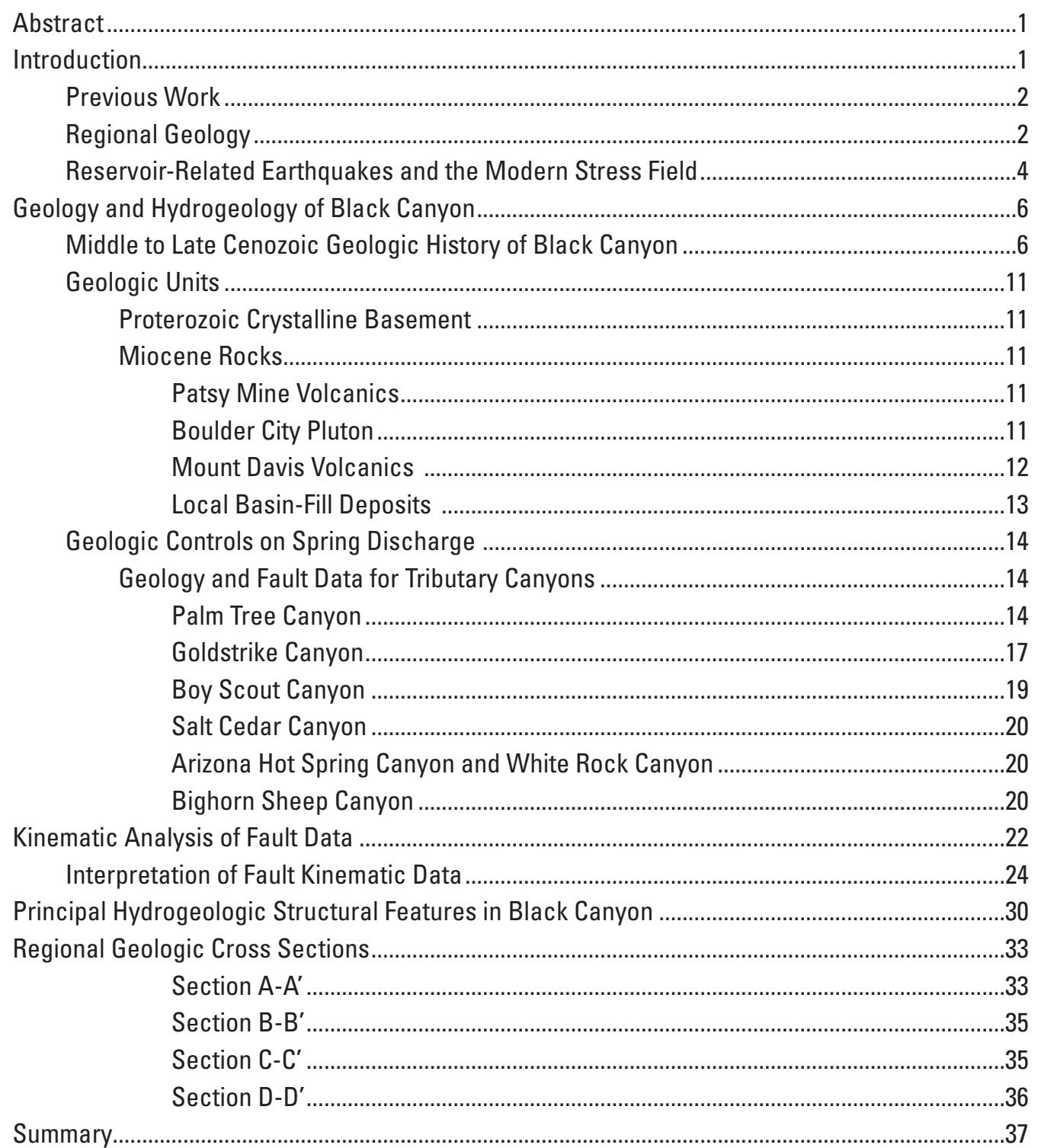




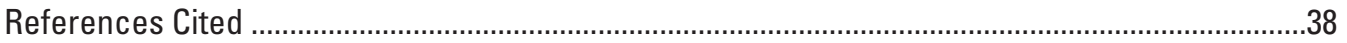

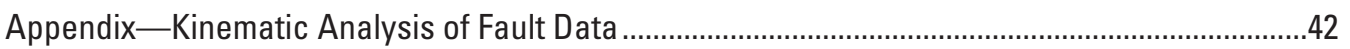

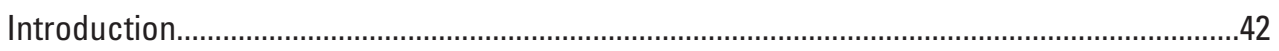

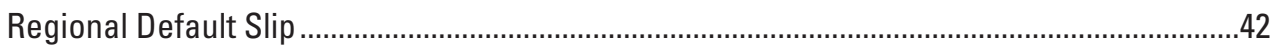

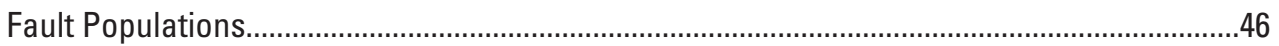

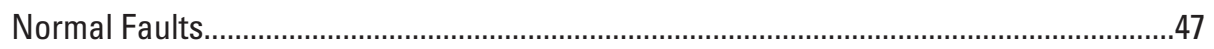

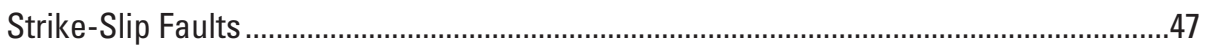

\section{Figures}

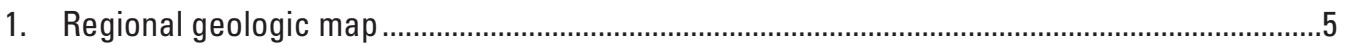

2. Geologic map of Black Canyon study area .........................................................................

3. Photograph showing view of southwest-facing margin of Black Canyon by Arizona portal below Hoover Dam. ......................................................................................................10

4. Photograph showing view to the northwest of spring discharging from a splay of the Palm Tree Fault in Palm Tree Canyon.....................................................................................14

5. Photographs showing spring seepage in Palm Tree Canyon and a view from mouth of Palm Tree Canyon, looking across the Colorado River ..... 15

6. A, Equal-area stereonet plots of all faults measured in Palm Tree Canyon. $B$, Kinematic faultplane solution derived from ten faults measured within Palm Tree Canyon. $C$, Schematic diagram of right-sense fault step-over of Palm Tree Fault Zone.

7. Photograph showing oblique view to southeast of Palm Tree Fault in lower Goldstrike Canyon.

8. A, Plot of fault planes and striae from the northern end of Salt Cedar Fault System, over kinematic fault-plane solution derived from the same faults. $B$, Photograph showing horizontal striae on a segment of the Salt Cedar Fault, measured on north side of Goldstrike Canyon. $C$, Photograph showing view to east of strand of Palm Tree Fault Zone west of Salt Cedar Fault in Goldstrike Canyon. $D$, Photograph showing view to south along Salt Cedar Fault.

9. $A$, Photograph of seepage along fracture in Boy Scout Canyon, $B$, View showing one of several faults and fractures near the mouth of Boy Scout Canyon. $C$, Stereonet plot of fractures measured near seeps, showing average dip of 43 degrees to the southeast.

10. A, Quickbird false-color imagery showing vegetation in Salt Cedar Canyon. $B$, Photograph showing view to north along Salt Cedar Fault at the head of Salt Cedar Canyon. $C$, Photograph showing thermal waters discharging from an orifice at the margin of the dacite intrusion.

11. A, Geologic map of the White Rock and Arizona Hot Spring Canyons (AZWR) B, Photograph showing view to west of north-dipping normal fault in White Rock Canyon that controls the White Rock seeps. $C$, Stereonet plots of faults near the seeps.

12. Photographs showing $(A)$ view to northeast along trace of Bighorn Fault. $B$, View of north side of Bighorn Canyon. $C$. Cross-cutting striae, indicated by dotted lines, on a fault surface in Bighorn Canyon.

13. A, Equal-area stereonet of poles to all faults. $B$, Rose histograms of fault strike .................24

14. Equal-area stereonets and kinematic fault-plane solutions from normal fault subsets in Arizona Hot Spring-White Rock (AZWR) Canyons 
15. Equal-area stereonets and rose histograms of west- to south-dipping normal faults with dips less than or equal to 60 degrees..................................................................................26

16. $A$, Equal-area stereonet plot of east-west strike-slip fault planes measured at northern end of study area, overlain on kinematic fault-plane solution. $B$, Geologic map of northern part of study area west of Hoover Dam.

17. Summary of some published extension directions for the southwestern Lake Mead area..29

18. Schematic map showing in-situ declination of paleomagnetic data from 19 sites in the Tuff of Hoover Dam and other Mount Davis volcanic rocks (Geissman and others, 1989). ..29

19. Geologic map showing thermal springs in northern Black Canyon area and presence or absence of Lake Mead component of groundwater shown in relation to major faults..31

20. Locations of maximum horizontal gravity gradient steps from Langenheim and others (2010).

21. Generalized geologic map showing locations of cross sections

A1. Equal-area stereonet plots, rose diagrams, and kinematic fault-plane solutions.

A2. Kinematic fault-plane solutions for $(A)$ all faults defaulted to normal. $B$, Strike-slip faults defaulted to normal.

A3. Equal-area stereonets of fault planes and striae, rose histograms of fault strike and dip, rose histograms of striae trend and plunge and kinematic fault-plane solutions of subset 1, low-angle normal faults_-faults with striae rake $>45^{\circ}$ and fault dip $\leq 60^{\circ} \ldots . . .48$

A4. Equal-area stereonets of fault planes and striae, rose histograms of fault strike and dip and striae trend and plunge, and kinematic fault-plane solutions of subset $1 \mathrm{a}-$ westto south-dipping normal faults with dips $<60^{\circ}$.

A5. Equal-area stereonets of fault planes and striae and rose histograms of fault strike and dip and striae trend and plunge of subset $1 \mathrm{~b}$-east-dipping normal faults of with dips $\angle 60^{\circ}$. 58

A6. Equal-area stereonets of fault planes and striae, rose histograms of fault strike and dip and striae trend and plunge, and kinematic fault-plane solution of subset 2 -normal faults with dips $\geq 60$ population.

A7. Equal-area steronet plots of fault planes and striae and kinematic fault-plane solutions of fault subsets in Arizona and White Rock (AZWR) Canyons showing difference in strikes and extension directions between inferred older and younger normal fault sets, and conjugate style of both sets.

A8. Equal-area stereonets of fault planes and striae, rose histograms of fault strike and dip and striae trend and plunge, and kinematic fault-plane solutions of subset 3 - strikeslip faults defined as faults with rakes $\leq 45^{\circ}$.....

A9. Kinematic fault-plane solutions for east-west strike-slip faults in the northern part of study area and East-west strike-slip faults in Arizona and White Rock Canyons......................58

\section{Tables}

1. Geologic history of greater Lake Mead region, Nevada and Arizona. 3

2. Middle to late Cenozoic geologic history of Black Canyon, Nevada and Arizona 



\title{
Geologic Framework of Thermal Springs, Black Canyon, Nevada and Arizona
}

\author{
By L. Sue Beard, Zachary W. Anderson, Tracey J. Felger, and Gustav B. Seixas
}

\section{Abstract}

Thermal springs in Black Canyon of the Colorado River, downstream of Hoover Dam, are important recreational, ecological, and scenic features of the Lake Mead National Recreation Area. This report presents the geologic framework results from a U.S. Geological Survey study of the geohydrology and geochemistry of the springs. The study was conducted in cooperation with the National Park Service.

Exposures in Black Canyon are mostly of Miocene volcanic rocks, underlain by crystalline basement composed of Miocene plutonic rocks or Proterozoic metamorphic rocks. The rocks are variably tilted and highly faulted. Results of kinematic analysis of fault data collected along tributaries to the Colorado River indicate two episodes of deformation, consistent with earlier studies. The earlier episode formed during east-northeast directed extension, and the later during east-southeast directed extension. At the northern end of the study area, pre-existing fault blocks that formed during the first episode were rotated counterclockwise, probably during the later episode.

Spring discharge occurs along faults intruded by dacite dikes and plugs; weeping walls and seeps extend away from the faults in highly fractured rock or relatively porous volcanic breccias, or both. Two major structures are important for understanding groundwater-flow paths - the Palm Tree and Salt Cedar Faults. Palm Tree Fault is a right-lateral structure that extends northwest across Black Canyon, cutting older Patsy Mine volcanic rocks east of the Colorado River. West of the river, the fault forms a diffuse right-stepping zone within the Boulder City pluton where northwest-striking fault segments and associated extensional fractures are intruded by dacite dikes related to younger Mount Davis volcanic rocks. Springs and seeps discharge along the fault zone, including Palm Tree and Nevada Hot Springs. Differences in chemical and isotopic compositions of spring water occur north and south of the Palm Tree Fault Zone.

Salt Cedar Fault is a north-striking, west-side-down structure on the western side of Black Canyon, and is traceable along its southern extent by a 12 kilometer-long gravity gradient. Mount Davis dacite dikes, domes, and flows intrude along and overlie the fault in places. Three thermal springs discharge from the fault zone. The southern two, Salt Cedar and Boy Scout, discharge along dacite intruded into the fault. The third,
Nevada Hot Spring, is at the intersection of the Salt Cedar and Palm Tree Faults and has multiple discharge points from orifices on both fault planes. Here, Salt Cedar Fault has right-slip striae and offsets the Palm Fault 100 meters in a right-lateral sense. The right-lateral offset likely represents reactivation of the Salt Cedar Fault, possibly including some recent activity based on earthquake data collected in the 1970s that yielded a fault plane solution indicating right-lateral slip. The filling of Lake Mead increased pore pressure below the lake and where in hydraulic connection with underlying faults and fractures, may have triggered earthquakes and opened existing structures or created new structures, thereby enhancing spring discharge near the dam.

Regional cross sections in this report show that thick carbonate aquifer rocks of east-central Nevada do not extend into the Black Canyon area and generally are terminated to the south at a major tectonic boundary defined by the northeaststriking Lake Mead Fault System and the northwest-striking Las Vegas Valley shear zone. Faults west of Black Canyon that strike dominantly north-south form a complicated pattern that may inhibit easterly groundwater movement from Eldorado Valley. To the east of Black Canyon, crystalline Proterozoic rocks locally overlain by Tertiary volcanic rocks in the Black Mountains are bounded by steep north-south normal faults to both the east and west. These faults may also inhibit westerly groundwater movement from Detrital Valley toward Black Canyon. Finally, the cross sections show clearly that Proterozoic basement rocks and/or Tertiary plutonic rocks are shallow in the Black Canyon area (few hundred meters) and are cut by several major faults that discharge most of the springs in the Black Canyon. Therefore, the faults most likely provide groundwater pathways to sufficient depths that the groundwater is heated to the observed temperatures of up to $55^{\circ} \mathrm{C}$.

\section{Introduction}

This report presents the geologic framework critical in understanding spring discharge and the hydrogeology in Black Canyon directly south of Lake Mead below Hoover Dam, Nevada and Arizona. Most of the springs are thermal 
with temperatures as much as $45-55^{\circ} \mathrm{C}$. The study is part of a hydrogeologic and geochemical study of the Black Canyon thermal springs by the U.S. Geological Survey, funded by the National Park Service and National Cooperative Geologic Mapping Program of the U.S. Geological Survey. The study consisted of (1) compilation of existing geologic mapping, augmented by new field geologic mapping and geochronology (Felger and others, 2014), (2) collection and analysis of structural data adjacent to the springs of interest (appendix 1; Anderson and Beard, 2011; Beard and others, 2011a), and (3) construction of regional cross sections (pl. 1). The most significant results identify faults, fracture zones, and rock characteristics that influence the hydrogeology of Black Canyon. Additional results include refinement of the volcanic stratigraphy based on field mapping and new geochronology. This report will be integrated into a companion hydrogeologic report that includes new geochemical and spring flow data that describes groundwater components of Black Canyon thermal springs (M. Moran, written commun, 2013).

\section{Previous Work}

Previous hydrogeologic studies of the thermal springs in Black Canyon suggested a hydraulic connection between Lake Mead and the aquifer system that feeds the springs. McKay and Zimmerman (1983) presented discharge and chemical data from 13 springs during a period of 16 months. They suggested several possible groundwater sources, including Lake Mead, regional groundwater, deeply circulating fluids, and minor local recharge. They also attributed the source of heat to shallow magmatic sources; however, local volcanic and intrusive rocks are too old to be a viable heat source.

Pohlmann and others (1998) studied 36 springs in the Lake Mead area, including 17 in Black Canyon. They classified springs as having dominantly local, subregional, or Lake Mead sources, and noted that the Lake Mead component in the springs ends about $2.4 \mathrm{~km}$ south of the dam. The elevated temperatures were attributed to "deeper" circulation of subregional groundwater, and they suggested the springs were controlled by north-south striking normal faults.

The companion hydrogeologic report under preparation by the US Geological Survey (M. Moran, written commun., 2013; preliminary results reported in Justet and Beard, 2010, and Justet and others, 2011) indicates the thermal waters in northern Black Canyon are a mixture of water from Lake Mead, deeper thermal groundwater flowing through high $\delta^{87} \mathrm{Sr}$ Proterozoic crystalline basement, and recharge from local highlands. The Lake Mead component appears to be present at discharge sites in Black Canyon north of a northwest-striking right-lateral fault, herein called the Palm Tree Fault.

Previous geologic reports pertinent to this study include a body of work by R.E. Anderson, comprising two 15-minute geologic quadrangle maps that include the Black Canyon study area (Anderson, 1977, 1978) and Anderson (1969, 1971), Anderson and Laney (1975) and Anderson and others
(1972, 1994). Ekren and Anderson (1996) mapped the Boulder City 7.5-minute quadrangle, Mills (1994) mapped the Hoover Dam 7.5-minute quadrangle, and Smith (1984) mapped the Boulder Beach 7.5-minute quadrangle. Regional-scale geologic maps include Beard and others (2007) and Felger and Beard (2010). Anderson and others (1972), Gans and Bohrson (1998), and Faulds and others $(2001,2002)$ provide geochronologic ages on many of the geologic units to this study.

\section{Regional Geology}

The geologic setting of the Lake Mead region is the result of many events through geologic time, culminating in Miocene extension and later erosion by the Colorado River that shaped much of the modern landscape. These geologic events are important in understanding the hydrogeologic framework of Black Canyon. Table 1 summarizes the entire geologic history of the Lake Mead region. A regional geologic map from Felger and Beard (2010) shows geologic units referred to in this section (pl. 1). Unit labels in parentheses in the remainder of this section refer to the map and cross sections on plate 1; see Felger and Beard (2010) for the detailed description of map units. This map was used to construct regional geologic cross sections for this study.

The study area lies within the Proterozoic Mohave Province formed 1.79 to $1.74 \mathrm{Ga}$ (billion years before present), and is characterized by gneissic and plutonic rocks that are mostly low granulite to upper amphibolite facies (Thomas and others, 1988). Metamorphic garnet gneisses and schists, and granite gneiss are the predominant Paleoproterozoic rocks in the area (Xgn on pl. 1). Regionally, the rocks have undergone metamorphism and deformation, and subsequent intrusion by Paleoproterozoic and Mesoproterozoic granitic rocks. The rocks are locally intruded by ca $1.7 \mathrm{Ga}$ syndeformation granites or $1.4 \mathrm{Ga}$ postdeformation porphyritic granites (Duebendorfer and others, 2001).

A prolonged period of erosion of the Proterozoic craton formed a smooth, low-relief surface on which clastic and carbonate marine rocks of Paleozoic age were deposited along the cratonic platform and continental shelf of western North America. The sedimentary rocks, from Cambrian through Permian in age, include limestone, dolomite, sandstone, siltstone, claystone, and minor evaporite (€tb, €cu, DSu, Dtb, MDu, Mr, PMu, Pr, Pkt on pl. 1). The deposits thicken westward toward the miogeocline.

Triassic and Jurassic fluvial, eolian, marginal marine and nearshore marine clastic sedimentary rocks ( $\mathrm{ku}$, Jam) accumulated east of the Cordilleran magmatic arc related to subduction along the western margin of North America. East- and southeast-directed Late Mesozoic (Sevier-age) thrust faults north and west of the study area telescoped the Paleozoic and Mesozoic sedimentary rocks into thrust sheets, creating the Sevier highlands. Frontal thrusts of the system include the Keystone thrust to the west in the Spring Mountains and the equivalent Muddy Mountain thrust to the north in the Muddy 
Table 1. Geologic history of greater Lake Mead region, Nevada and Arizona.

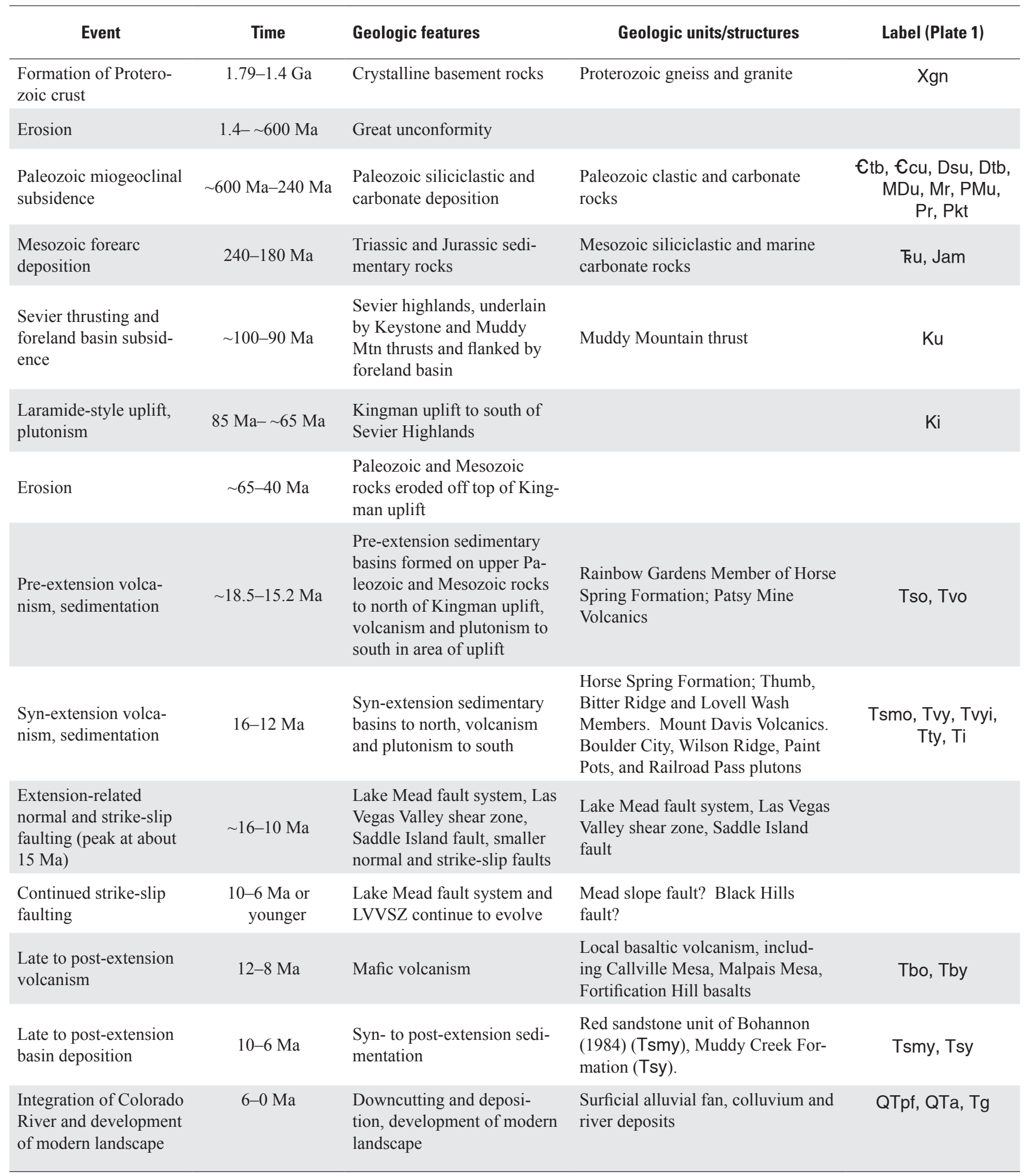


Mountains. Foreland basin deposits are locally preserved south and east of the Muddy Mountain thrust (Ku; Bohannon, 1983).

In Latest Cretacous to early Tertiary time, the area of southeastern Nevada and northwestern Arizona was uplifted through crustal thickening, by Laramide-style basement-cored uplift and pluton emplacement. Late Cretaceous intrusive rocks include 65-73 Ma two-mica, garnet-bearing plutons (Ki) in the Black Mountains that were intruded as much as $10 \mathrm{~km}$ deep in the core of the uplift (Faulds and others, 2001). The Kingman uplift (or Kingman arch; named by Lucchitta in Goetz and others, 1975), is a north trending, north plunging arch between the Sevier thrust belt to the west and north, the Mesozoic Cordilleran magmatic arc to the west, and the Colorado Plateau to the east (Beard and Faulds, 2011). Protracted erosional beveling of the uplift removed the entire Paleozoic and Mesozoic section across its top and erosionally truncated them on its flanks. On the northern side of the arch in the Lake Mead region, the erosional beveling is preserved as an unconformity beneath pre-extension Cenozoic sedimentary rocks. Here, the beveling cuts from Late Cretaceous foreland basin deposits on the north into progressively older rocks to the south; where last preserved at Frenchman Mountain, the beveling has cut down to lower Triassic strata (Bohannon, 1984). Similarly, progressive south and west beveling of Paleozoic strata is preserved on the western margin of the Colorado Plateau in northwestern Arizona, such that only the basal Paleozoic rocks are preserved beneath Cenozoic rocks at southwestern most outcrops. The result is that although Paleozoic and Mesozoic rocks are widely exposed north of Lake Mead and on the Colorado Plateau, they were completely removed from the study area and surrounding region prior to the onset of volcanism and extension in the early Miocene (Faulds and others, 2001). Regionally, isolated sediments (Tso) preserved pre-extensional evidence for the Kingman uplift. In the southern Lake Mead region, pre-extensional sedimentation is constrained to local arkosic deposits filling low-relief areas of the Kingman uplift, whereas to the north, thin clastic and carbonate sediments were deposited on beveled upper Paleozoic and Mesozoic rocks.

Pre-extension volcanism and associated plutonism began to the south at about $20 \mathrm{Ma}$ and migrated northward, reaching the study area possibly by about $18.5 \mathrm{Ma}$ and continuing until about 15.2 Ma (Anderson and Beard, 2010). The early volcanism (Tvo) was followed quickly by widespread extensional tectonism that peaked at about $15 \mathrm{Ma}$. Renewed volcanism after peak extension continued regionally until about $12 \mathrm{Ma}$ (Tvy, Tvyi, Tty; Faulds and others, 2001) and locally until about $4 \mathrm{Ma}$. Associated plutonism (Ti) in the Lake Mead area included the Miocene-age Boulder City, Wilson Ridge, Paint Pots, and Railroad Pass plutons. Extension in the corridor was accompanied by pluton emplacement, normal faulting, stratal tilting, and basin formation; the basins filled with volcanic rocks and intercalated coarse clastic sedimentary rocks and some evaporite and fine-grained clastic sediments. Coeval faulting and volcanism disrupted and offset older extensional basins and volcanic centers and formed new ones, resulting in a complex pattern of cross-cutting faults and variably tilted volcanic and sedimentary rocks.
Deformation along the Lake Mead Fault System (LMFS) and Las Vegas Valley shear zone (LVVSZ), just to the north of Black Canyon (fig. 1), was dominantly by linked normal and strike-slip faults, most active at about 16-14 Ma in the eastern Lake Mead region and at about 10-12 Ma in western Lake Mead (Duebendorfer and others, 1998; Anderson and Beard, 2010). Diminished rates of strike-slip faulting probably continued to at least $6 \mathrm{Ma}$, or younger locally. Basins filled with clastic, evaporite, and carbonate rocks (Tsmo, Tsmy) formed along these complex strike-slip and extensional fault systems. Documented horizontal displacement along the LMFS in western Lake Mead is about $20 \mathrm{~km}$; and cumulative slip along the entire system is estimated at as much as $65 \mathrm{~km}$ (for example, Anderson and Beard, 2010). The LMFS strikes northeast from Eldorado Valley through Hemenway Wash just north of Hoover Dam and continues to the Virgin River depression, a large basin that underlies the Virgin River Valley, Nevada. Slip along the LVVSZ is as much as $40-60 \mathrm{~km}$ near the Las Vegas Range, decreasing to zero southeast where it intersects the LMFS (Duebendorfer and Simpson, 1994). At its southeastern end, the LVVSZ splays into two main strands; one that extends north of Sunrise Mountain and the other south of Frenchman Mountain (fig. 1). The LVVSZ and LMFS formed during combined eastwest extension and south-directed contraction.

The western part of the LMFS juxtaposes a southern terrane of crystalline basement rocks overlain by Cenozoic volcanic and sedimentary rock against a northern terrane of Paleozoic, Mesozoic, and Cenozoic stratified rocks (Anderson, 1973). Volcanic centers erupted along the LMFS, from about 13 to $8 \mathrm{Ma}$, and constitute the northernmost igneous rocks of the Colorado River extensional corridor; they both intrude and are cut by the LMFS. No significant exposures of igneous rocks occur within an amagmatic gap between the northern Colorado River extensional corridor and the southern end of volcanism in Lincoln County, Nevada (Eaton, 1982). As extension and volcanism waned, basin sedimentation (Tsy) and basaltic volcanism (Tbo) filled low areas of basin-range topography with smoothfloored valleys, such as Eldorado Valley to the west (which is still depositing sediment; QTpf). At about $6 \mathrm{Ma}$, integration of and down cutting by the Colorado River and its tributaries cut through and exposed deeper parts of the region, such as the basin underlying Detrital Valley and bedrock areas of Black Canyon. Minor volcanism, from about 6 to $4 \mathrm{Ma}$, formed isolated basaltic flows (Tby) along the eastern and western sides of the Black Mountains, including Fortification Hill basalt, that grade to varying levels of the dissected landscape (Tg, QTa).

\section{Reservoir-Related Earthquakes and the Modern Stress Field}

The Mead Slope Fault and Black Hills Fault (fig. 1) are two large faults near Black Canyon with documented Quaternary offset that may be important regional hydrogeologic structures and provide information on present-day stresses. Studies of these faults have focused on their earthquake potential in 


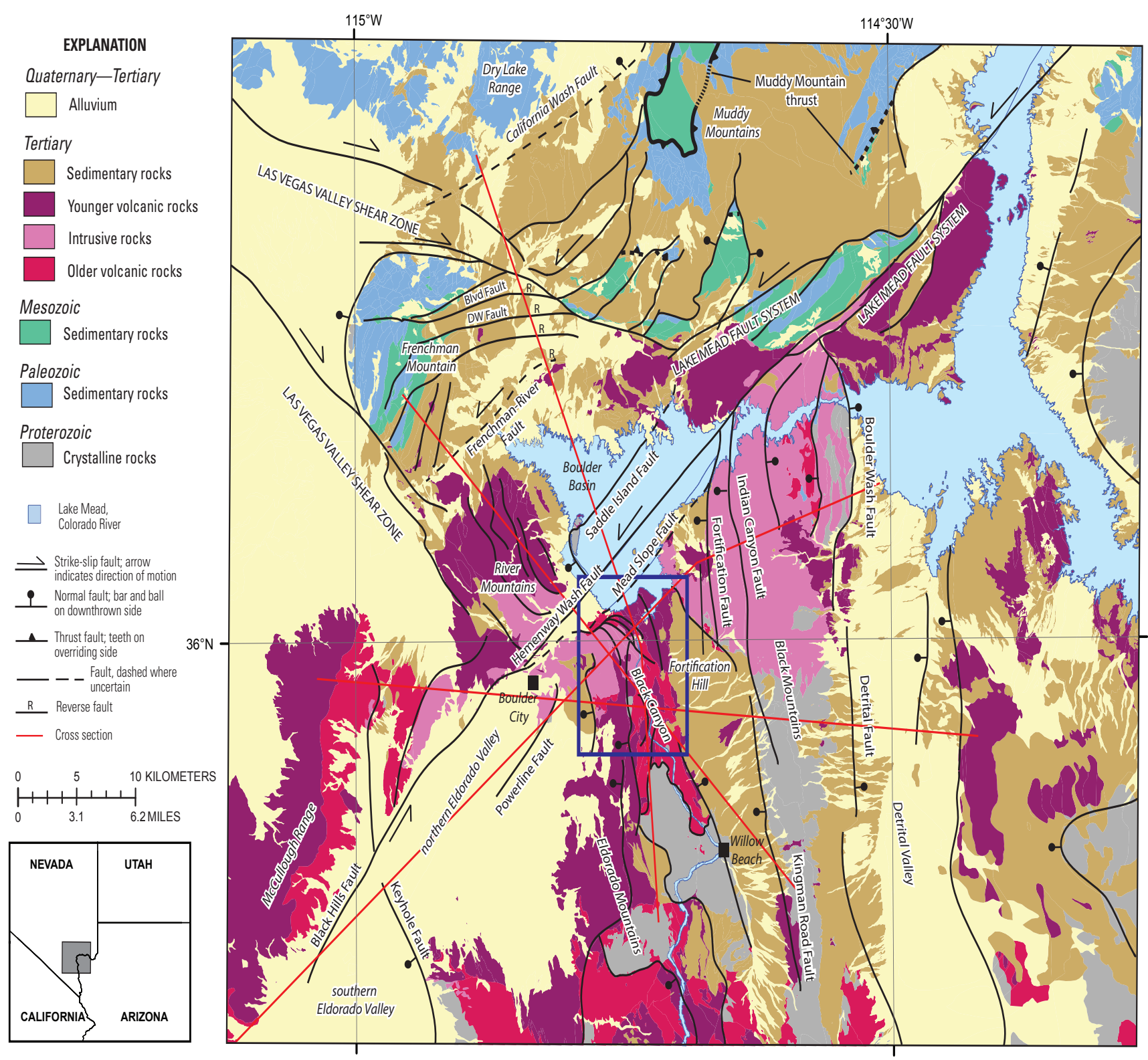

Figure 1. Generalized geology, showing geographic features and major fault systems discussed in text, of Lake Mead region, Nevada and Arizona (slightly modified from Felger and Beard, 2010). Geology and faults are generalized from 1:250,000-scale geologic map of same area presented in plate 1 (Felger and Beard, 2010). Purple box shows area of figure 2. Blvd Fault, Boulevard Fault; DW Fault, Dry Wash Fault.

relation to Hoover Dam (Anderson and O'Connell, 1993). The Mead Slope Fault strikes east-northeast and is exposed along the northern flank of Fortification Hill east of Hoover Dam. This fault is part of the LMFS and most likely had, at some point in its history, left-lateral offset with a small reverse component of slip (Anderson and O'Connell, 1993; Taylor and dePolo, 2002). Smith and others (2008) correlate two magnitude 3.8 seismic events in 1988 to modern movement on this fault.

The Black Hills Fault, exposed on the southeastern side of the McCullough Range, strikes northeast and has east-side-down Quaternary offset (Anderson and O’Connell, 1993; Fossett, 2005); it most likely represents the southwestern extent of LMFS. Other strands of the LMFS to the east in Overton Arm and the Virgin Mountains also show local Quaternary offset (Beard and others, 2007).

Studies have thoroughly documented an increase in local earthquake activity related to the filling of Lake Mead in 1938 and subsequent cycles related to rapid large changes in reservoir water level (Carder, 1945; Rogers and Lee, 1976; Meade, 1985; Anderson and O’Connell 1993). Earthquakes triggered by the lake occurred on existing structures and released tectonic stresses that reflect the regional stress field. Many of the earthquakes were localized in the vicinity of Boulder Basin (fig. 1), and at least some of the events were 
associated with steeply dipping mapped faults (Carder, 1945; Rogers and Lee, 1976), although no scarps or other earthquake-related features were identified. Fault-plane solutions for earthquakes measured during a study in 1972-73 (Rogers and Lee, 1976) indicate right-lateral strike-slip on northerly striking fault planes such as the faults that bound the northern Black Mountains, and normal faulting on northeast-striking faults, mostly along the inferred trace of the LMFS below Lake Mead. The two major causes for seismicity induced by impoundment of the Colorado River to form Lake Mead are (1) elastic loading and (2) increased pore-pressure, which decreases effective normal stress (Anderson and Laney, 1975; Simpson and others, 1988). The elastic loading effects of the lake are only a factor for earthquakes beneath and immediately adjacent to the lake; typically, the earthquake response was almost immediate. However, pore-pressure diffusion away from the lake, most likely by fluid connectivity along faults and fractures that intersect the reservoir, is the dominant mechanism for the larger magnitude earthquakes that extend beyond the immediate vicinity of the lake (Anderson and Laney, 1975; Simpson and others, 1988; Anderson and O'Connell, 1993). These earthquakes can activate pre-existing faults and fractures if the state of stress near the faults is already near failure. Anderson and Laney (1975) pointed out that a hydraulic connection between lake water and deep, sometimes buried, faults and fractures was needed in order to trigger seismicity, because increased pore pressure from the load of the lake and enhanced fluid connectivity reduces the effective stress on faults and fractures. They attributed reduced seismicity in the Lake Mead area east of the Black Mountains to subsurface evaporites forming a barrier to hydraulic connectivity between lake waters and faults and fractures. Fluid flow along fault zones may precipitate minerals, which serve to seal fractures and reduce fault permeability (Maurer and others, 2004). Renewed seismicity on a fault may act to reopen fractures or form new ones, resulting in a fault alternating between allowing and restricting hydraulic connectivity depending on the location and degree of seismicity and mineral precipitation. Therefore, very young or seismically active faults and fractures are most likely to have the greatest influence on fluid flow and spring discharge. McKay and Zimmerman (1983) concluded that during the filling of Lake Mead, fracturing related to reservoir-induced seismicity increased, as did groundwater potential related to the increasing hydraulic head. They suggested this led to an increase in discharge from both existing and new springs.

The modern extensional stress direction is likely northwest-southeast to west northwest-east southeast (Zoback and Zoback, 1980; Patton and Zandt, 1991; Flesch and Kreemer, 2010) placing north-south to northeast-southwest fault planes under relative tension, albeit at low strain rates (Hammond and Kreemer, 2008). These results are consistent with faultplane solutions from modern earthquakes in the Lake Mead region (Rogers and Lee, 1976). Conceptually, the modern stress field in relation to fault plane orientations can yield important insights into fault-related groundwater flow paths because fault planes under relative tension can be conduits for groundwater, whereas those in shear or compression are more likely to deflect or impede groundwater movement (Faunt, 1997). Therefore, in theory, north- to northeast-striking faults in the study area should be under relative tension and northwest-striking faults under relative compression. Other fault characteristics that may control groundwater flow include the amount of fault offset, the rock lithology juxtaposed along the fault, and material properties of the fault zone. In summary, understanding the detailed geology of faults in the Black Canyon study area is crucial to interpreting potential geologically controlled groundwater-flow paths, recharge, and spring discharge.

\section{Geology and Hydrogeology of Black Canyon}

Black Canyon includes numerous thermal springs and seeps that emerge along faults, fractures, and contacts within the low elevations of the canyon (approximately 300-200 $\mathrm{m})$. The rock units and structures influence the distribution of springs, and in this report, we describe the middle to late Cenozoic geologic history, geologic units pertinent to the hydrogeology, and fault history in and adjacent to Black Canyon from Promontory Point north of Hoover Dam and south to Bighorn Sheep canyon (fig. 2).

\section{Middle to Late Cenozoic Geologic History of Black Canyon}

The middle to late Cenozoic geologic history of Black Canyon is summarized in table 2. Volcanic rocks exposed in the Black Canyon area were erupted, subsequently faulted and tilted during a hiatus in volcanism, and then erupted and faulted again, forming a complex pattern of variably tilted volcanic rocks and multiple generations of dikes. Because the volcanic rocks were erupted from multiple sources, they form complex patterns of overlapping flow sequences. The oldest volcanic rocks are the ca 18.5-15.1 Ma Patsy Mine andesitic domes, flows and flow breccias, and rhyolitic domes, and age-equivalent rocks in the McCullough Range (Smith and others, 2010). They were deposited prior to extension onto an irregular surface of moderate relief underlain by Proterozoic crystalline rocks and locally a thin veneer of middle Cenozoic arkosic sedimentary rocks.

Extensional tectonism in the area began at about $15 \mathrm{Ma}$, during or just before eruption of the 15.2 Ma Tuff of Bridge Spring, a regional ash-flow tuff unit (Faulds and others, 2002) sourced from a caldera in the west-central Eldorado Mountains (Gans and Bohrson, 1998). This tuff unit is used to distinguish the Patsy Mine Volcanics from the younger Mount Davis Volcanics. Northernmost exposures of the Tuff of Bridge Spring are mapped about $5 \mathrm{~km}$ north of Willow Beach (fig. 1) on the 

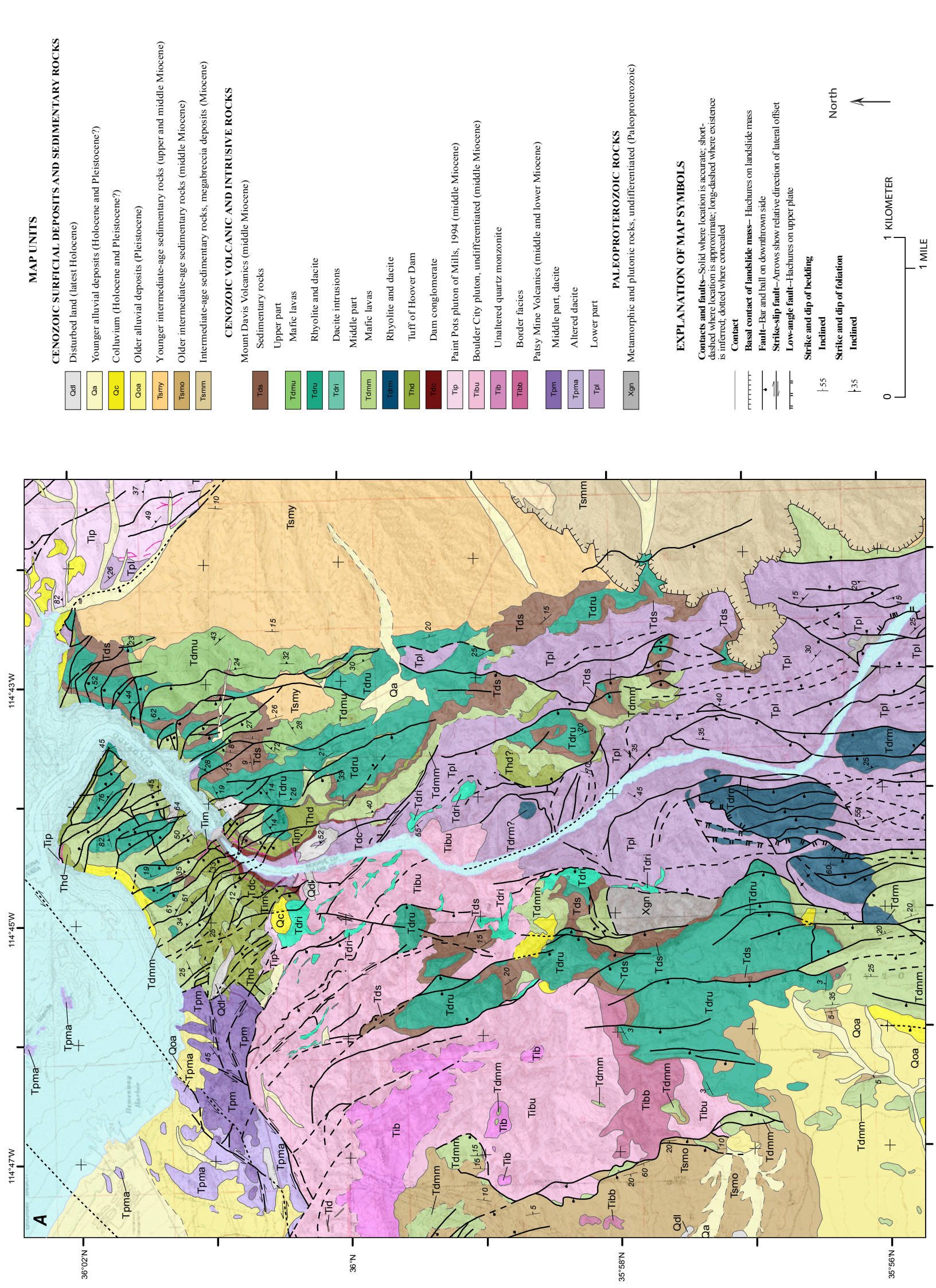

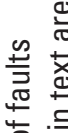
to. \& 茫 $\infty$ 赵 을 할 등 क्ष 을 돈 은 过 흔 灾 के के 类 $\frac{\pi}{3}$ 范要 둟 $\bar{\Sigma} \frac{0}{\infty}$ 过苛

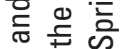
若 里 œ 实高

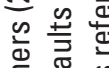
돔 $\frac{\pi}{5}$

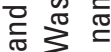
बे ए 등 ฮ 중 흐음 흥 롱응 ᄃ वृ ¿े $\sum^{\infty}$ 잉 远 ․ㅡㅁ 4 응 윻ㅎㅁ E 음 음 응 든 过 ष ․ N 言 के 

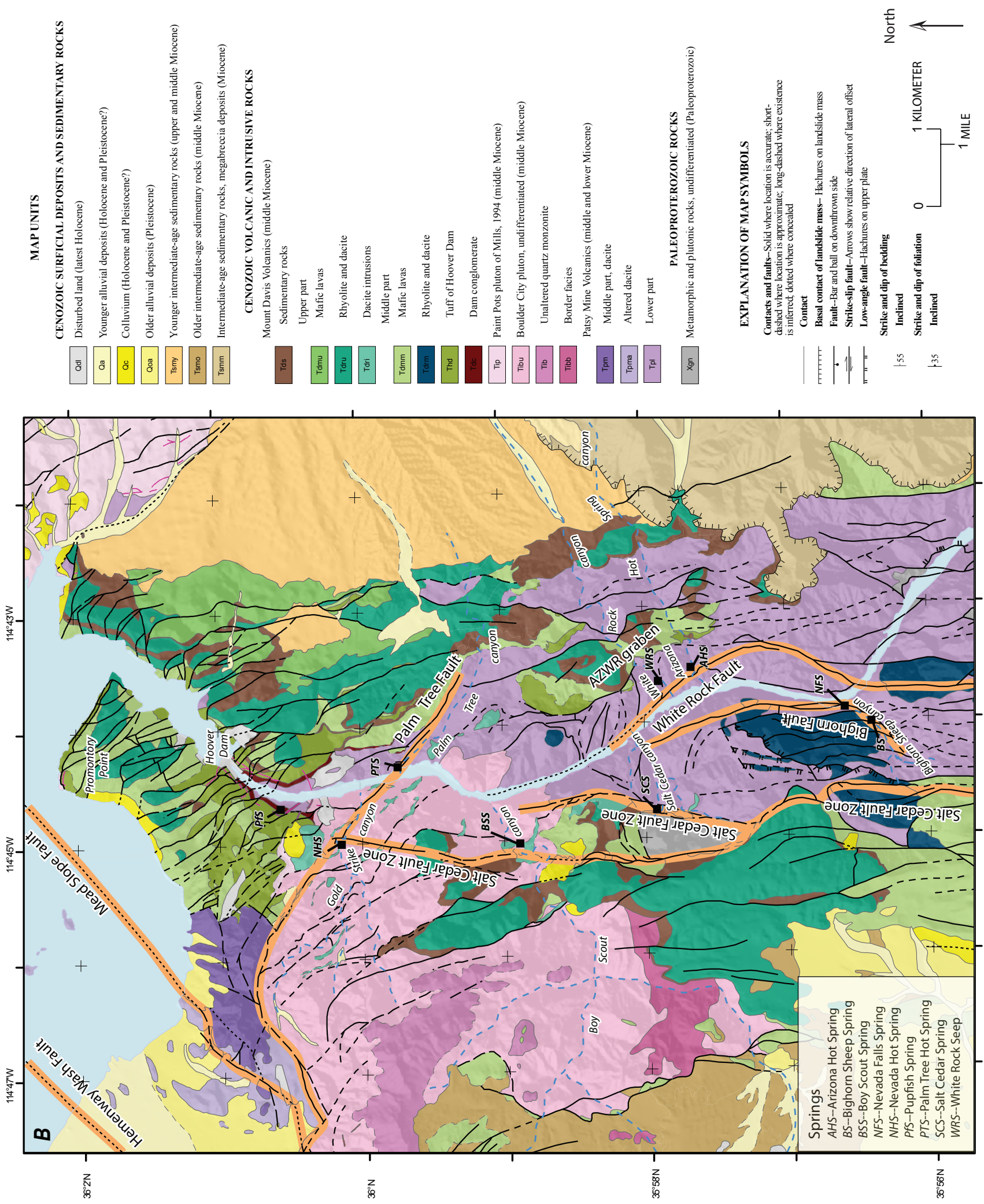

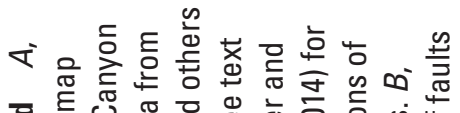

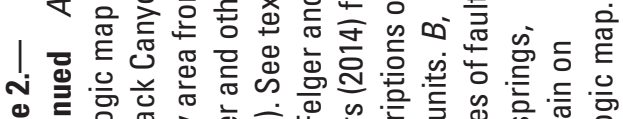

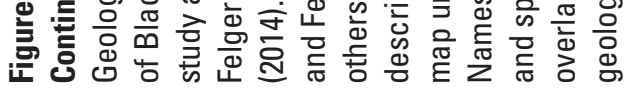


Table 2. Middle to late Cenozoic geologic history of Black Canyon, Nevada and Arizona.

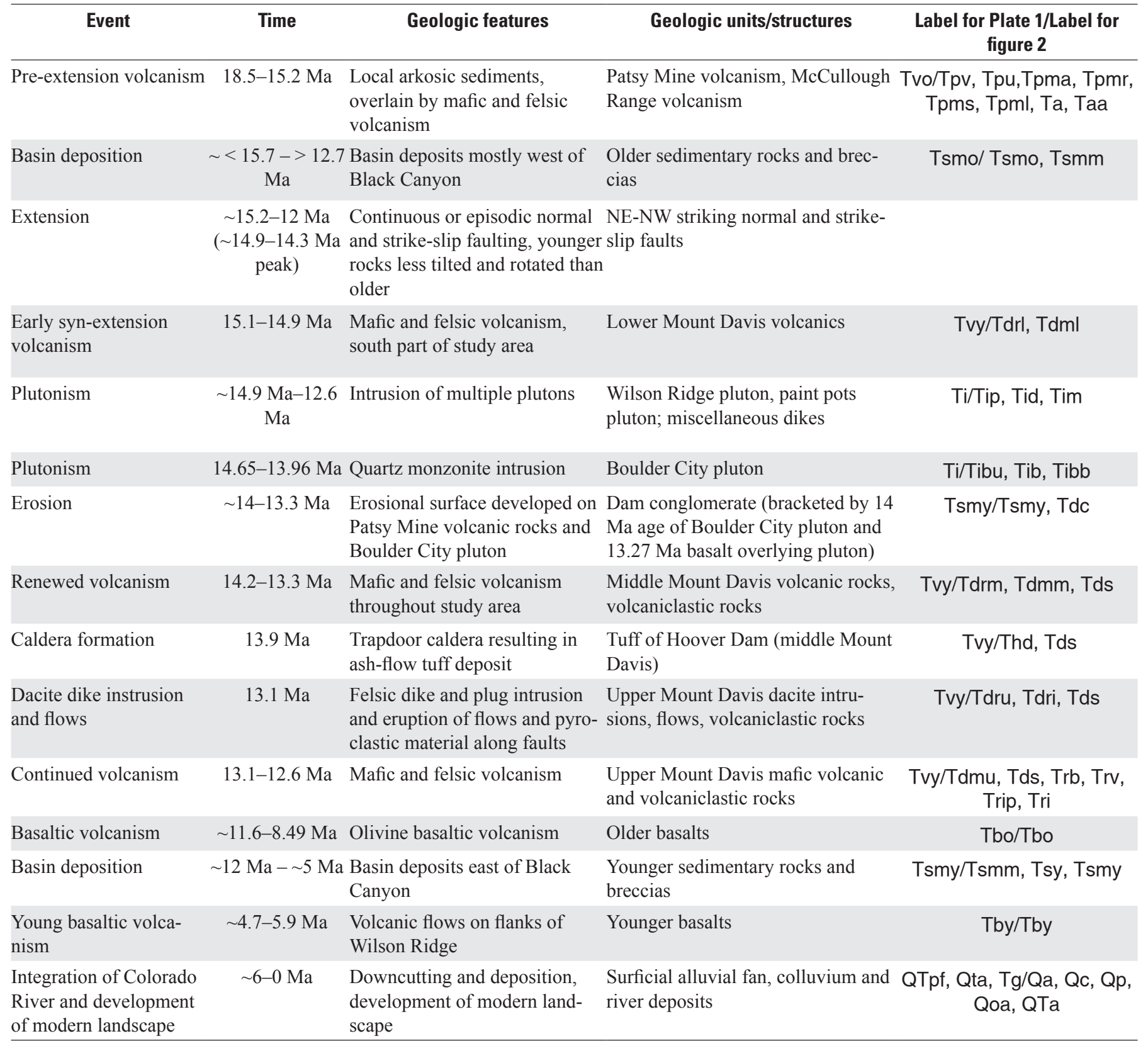

eastern side of the river. In northern Black Canyon, the Patsy Mine and Mount Davis Volcanics generally are separated by a conglomerate and sandstone unit (Dam Breccia of Ransome, reported in Bureau of Reclamation, 1950; Dam conglomerate of Mills, 1994) at the base of the Mount Davis Volcanics. In the River Mountains, volcanic rocks are deposited on lower Paleozoic sedimentary rocks, whereas to the south, volcanic rocks are deposited on crystalline basement rocks.

Peak extension coincides with a hiatus in Mount Davis volcanism from about 14.9 to 14.3 Ma (Gans and Bohrson, 1998; Faulds and others, 2001). According to Anderson and others (1994) and Gans and Bohrson (1998), the extension direction was about 260 degrees azimuth and accommodated by west-dipping normal faults that tilted rocks eastward as much as 90 degrees in the Eldorado Mountains to the south (fig. 1) but only about 40-50 degrees in the study area. The interplay between extension and volcanism is marked by changes in dip of volcanic units upward through the section, locally marked by an angular unconformity between older and younger volcanic units - the steepest tilts are in the Patsy Mine and lower Mount Davis volcanic rocks, and tilts are noticeably shallower in the middle and upper Mount Davis (Anderson and others, 1972). Typically, the Patsy Mine rocks dip about 20 degrees more than Mount Davis rocks in the study area. Middle and upper Mount Davis rocks mostly dip between 10 and 30 degrees eastward, and steeper locally. An 


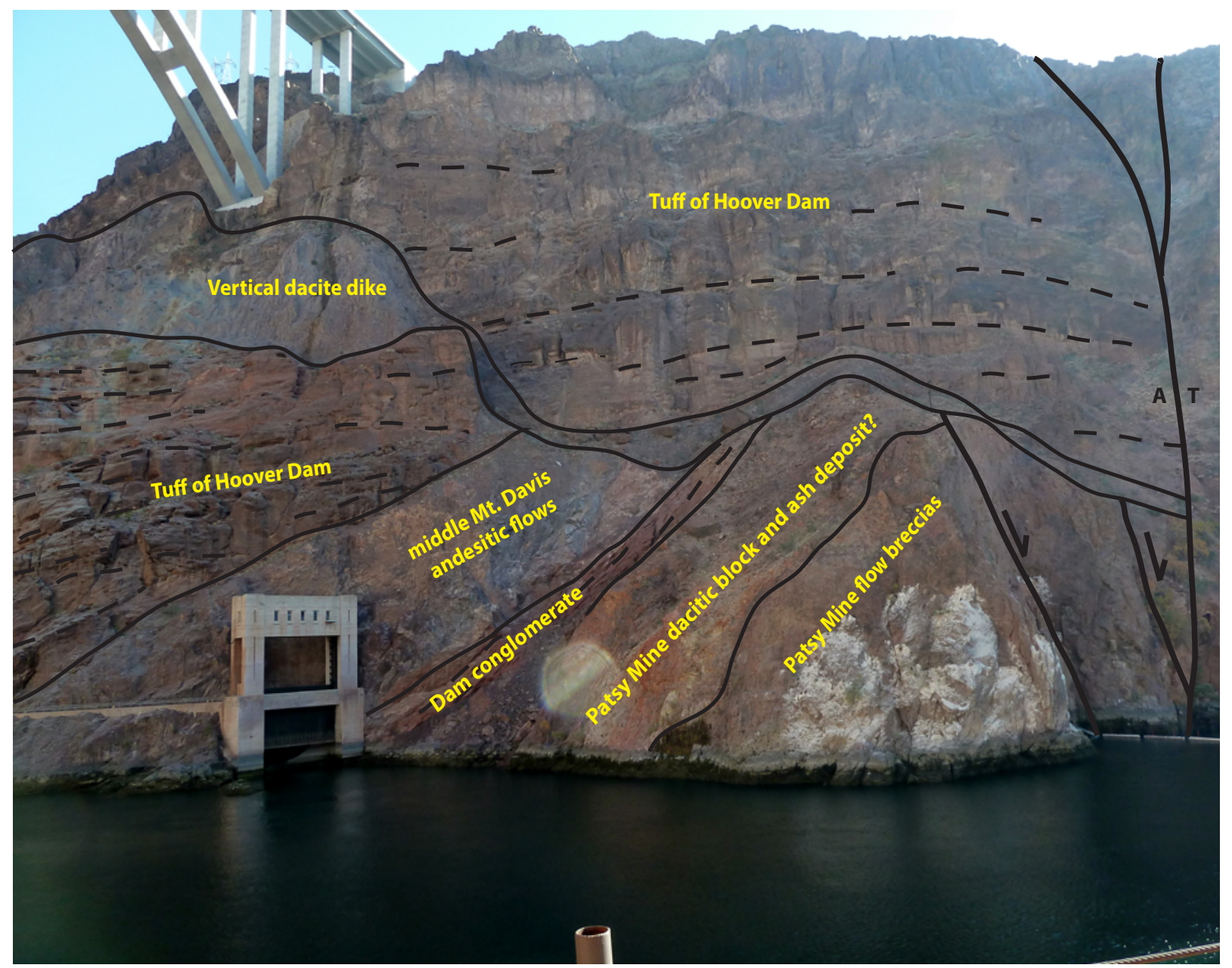

Figure 3. Photograph showing view of southwest-facing margin of Black Canyon by Arizona portal below Hoover Dam. Photograph shows fanning upwards dips in east-northeast dipping sequence ranging from Patsy Mine volcanic rocks to Tuff of Hoover Dam. Note that dip of Tuff of Hoover Dam decreases upward in view. Dike is parallel to canyon wall and plane of photograph. Steep faults on right side of view display oblique normal slip and do not cut the dike or tuff of Hoover Dam. Vertical fault at far right is right-lateral strike-slip fault; left side of fault labeled A moved away from viewer relative to side labeled T, which moved toward. (Photograph taken by L.S. Beard, U.S. Geological Survey, December 11, 2010).

excellent exposure illustrating progressively decreasing tilting upward through the volcanic section is shown on the southern side of Black Canyon near the boat launch ramp downstream of Hoover Dam (fig. 3).

Renewed volcanism from about 14.2 to $12.6 \mathrm{Ma}$ is represented by the middle and upper Mount Davis volcanic rocks. The volcanism began with an outpouring of andesitic flows, followed by eruption of the tuff of Hoover Dam, and culminating in a mixed volcanic sequence of basaltic andesite flows and dacite domes and flows. Wilson Ridge pluton to the east spans from $14.91 \pm 0.37$ to $12.96 \pm 0.332 \mathrm{Ma}$, but was intruded mostly between $13.94 \pm 0.38$ and $13.42 \pm 0.23$ Ma (Honn and others, 2010). The Patsy Mine and possibly the lower Mount Davis Volcanics were intruded by the Boulder City pluton at about $14 \mathrm{Ma}$. The youngest Mount Davis volcanic rocks are dacite to rhyolite domes, flows, dikes, and plugs that unconformably overlie Boulder City pluton on the western side of Black Canyon, and Patsy Mine
Volcanics on the eastern side of Black Canyon (fig. 2). This second phase of volcanism was accompanied by renewed faulting that was most likely related to south-directed constrictional strain and rotation along the LMFS (Anderson and others, 1994). Dacite dikes and plugs of this younger event intruded earlier faults, and volcanism outlasted faulting based on volcaniclastic facies associated with dacite domes and flows, which are faulted at the base, but not at the top. Gently tilted (about 5 degrees) older basalt flows, such as at Malpais Mesa in the southern part of the study area, also indicate a waning of extension-related tilting.

In addition to faulting related to the LMFS in the northern part of the study area, large, normal faults along the western side of the Black Mountains accommodated uplift and faulting of Wilson Ridge east of Black Canyon. The faults include the Fortification and Indian Canyon faults (fig. 1; Longwell, 1963; Mills, 1994). These faults acted as conduits for late basaltic volcanism (about 6-4 Ma), such 
as the Fortification Hill basalts (Templeton and Mills, 2005; Honn and Smith, 2010) and other flows on the western side of the Black Mountains, and unnamed flows on the eastern side. Young sedimentary rocks interbedded with the basalts are mostly coarse clastic deposits shed from nearby ranges.

\section{Geologic Units}

The main hydrogeologic units important to this study in Black Canyon include Proterozoic crystalline rocks, Patsy Mine Volcanics, Boulder City pluton, and Mount Davis Volcanics (fig. 2). The Mount Davis volcanic rocks have been subdivided in the Hoover Dam area by Mills (1994). Important units for this study that are described in the following sections include the dam conglomerate (Tdc), tuff of Hoover Dam (Thd), Sugarloaf dacite and equivalent flows, domes, intrusions (Tdru, Tdri), and a unit of associated mixed airfall tuff and volcaniclastic sediment (Tds). In addition, east and west of Black Canyon, sedimentary rocks (Tsmy and Tsmo), from a few meters to no more than $500 \mathrm{~m}$ thick in Eldorado Valley, overlie the Boulder City pluton and older volcanic rocks and are interlayered with or overlie the younger volcanic rocks. Locations of canyons referred to in this section are shown in figure $2 B$.

\section{Proterozoic Crystalline Basement}

Basement rocks in the Black Canyon area are dominantly biotite-garnet gneiss and schist, hornblendebiotite gneiss, with lesser granitic orthogneiss, and local layered amphibolite, leucogranite, and ultramafic rocks (Xgn). The crystalline basement rocks are widely exposed at Willow Beach (fig. 1) and on the western side of Black Canyon, and plunge northward beneath overlying volcanic rocks about $2 \mathrm{~km}$ south of Bighorn Sheep spring (BS, fig. 2). Only one small outcrop is present in northern Black Canyon, west of Salt Cedar spring (SCS, fig. 2). The exposures of crystalline basement rocks are mostly fault bounded, but south of Willow Beach the depositional contact of older volcanic rocks is locally preserved. The Proterozoic rocks are highly fractured, especially along the faulted margins of the exposures, but less so in the core of the large block near Willow Beach (Anderson, 1978).

Depth-to-basement geophysical models derived from potential field data (Langenheim and Schmidt, 1996; Langenheim and others, 2010) suggest that Proterozoic crystalline basement ranges from a depth of a few tens of meters to a few hundred meters beneath younger strata. Depths of Proterozoic basement rocks are variable owing to the irregular basement surface on which the volcanic rocks were deposited, the local effect of faulting and tilting, small contrast in specific gravity between volcanic and basement rocks, and inherent limitations in the geophysical models.

\section{Miocene Rocks}

In this section, we describe Miocene geologic units that are important to the hydrogeology of Black Canyon. Geologic unit labels in parentheses refer to figure 2 or the companion U.S. Geological Survey Open-File Report 2013-1267A by Felger and others (2014).

\section{Patsy Mine Volcanics}

The Patsy Mine Volcanics, named by Longwell (1963) and described by Anderson (1971) for the outcrops in the west-central Eldorado Mountains, are informally divided into lower (Tpl), middle (Tpm), and upper (Tpu). The lower and upper parts are dominantly andesite, and the middle part is rhyolite (Tpmr). Northward in Black Canyon, Anderson (1978) did not divide the Patsy Mine Volcanics but suggested that rocks there are correlative to the lower part. The lower and upper parts are quite similar and consist of andesite and basaltic andesite flows and explosion breccia. Patsy Mine Volcanics are mostly faulted against underlying Proterozoic rocks, but rare exposures of the contact include a few meters of prevolcanic clastic rocks. The Patsy Mine Volcanics range in age from younger than 18.5 Ma to older than the Tuff of Bridge Spring (Tb) at about 15.2 Ma (Faulds and others, 2002).

The Patsy Mine rocks in Black Canyon are stacks of layered volcanic flow breccia in Salt Cedar Canyon, lower White Rock Canyon, and on the Arizona side of the Colorado River below Hoover Dam (fig 2). Below Hoover Dam, the layered flows strike roughly north-south and dip east, parallel to the river. In Salt Cedar and White Rock Canyons, the flows strike east-northeast, dip south, and control the trend of both canyons. Although the change in attitudes of the flows is in part structurally controlled, it also may be related to the development of adjacent stratovolcanoes and domes. Rocks mapped as Patsy Mine in upper White Rock and Arizona Hot Spring Canyons are herein interpreted as the core and flanking flows of an andesite dome complex. Southward from Hoover Dam, Patsy Mine Volcanics are mostly andesitic flow breccias. West of Hoover Dam, a faulted section of dacite flows, interbedded debris flow breccias, sedimentary breccias, and highly altered dacitic rocks mapped by Smith (1984) were tentatively correlated to the middle Patsy Mine Volcanics (Tpm, Tpma). If so, a transition from that heterolithic assemblage to volcanic flow breccias must occur in the subsurface just west of Hoover Dam.

\section{Boulder City Pluton}

The Boulder City pluton (Tibu, Tib, Tibb) ranges in composition from fine- to medium-grained quartz monzonite to granite, and is biotite-hornblende bearing. The pluton is somewhat porphyritic, with a medium-grained crystalline interior that grades to porphyritic aphanites at the margin (Anderson, 1969; Ekren and Anderson, 1996). According to 
Anderson (1969), the pluton intrudes Patsy Mine volcanic rocks, although almost all intrusive contacts are obscured by faulting. Upper Mount Davis rocks are deposited on what Anderson (1969, p. B36) describes as "a rather featureless erosion surface developed on the pluton." The northern part of the pluton, which is well-exposed in Goldstrike Canyon (fig. 2), is very faulted and brecciated, and intruded by dikes. Faults with mostly westward moderate dips are marked by broad zones of breccias that are cut by steep north to northwest-striking oblique right-lateral faults. The southern and southeastern parts of the pluton are a border facies consisting of porphyritic aphanites (Ekren and Anderson, 1996). In Boy Scout Canyon (fig. 2), the pluton is cut by northeast-striking fractures that appear to parallel the margin of the pluton and may be related to pluton emplacement or cooling.

In northern exposures of the pluton, from Boulder City east to the Colorado River, the rocks are overprinted by mineralized zones of hematite, barite, calcite, and manganese oxide. Faults that cut the northern end of the pluton and volcanic rocks in the River Mountains to the north locally contain barite-manganese oxide veins. This mineralization is overprinted by sub-horizontal zones of hematization in volcanic rocks, the pluton, and overlying and adjacent clastic rocks east of Boulder City. The mineralization ends abruptly upward; this sharp upward termination was interpreted by Anderson (1969) as a paleohydrologic feature representing a long-lived, fluctuating water table. Field observations for this study indicate that the paleohydrologic feature is a result, at least in part, of mobilizing the earlier, subjacent, unrelated mineralization and concentrating it along the upper part of the water table.

Isotopic ages for the Boulder City pluton include a K-Ar age of $14.17 \pm 0.6 \mathrm{Ma}$ on biotite (recalculated; Anderson and others, 1972), and $14.65 \pm 0.5 \mathrm{Ma}$ on biotite (recalculated; R. Fleck, U.S. Geological Survey, written commun., 2008). A new U-Pb zircon age of $13.98 \pm 0.25 \mathrm{Ma}$ (Felger and others, 2014), indicates that the pluton intruded previously faulted Patsy Mine and lower Mount Davis volcanic rocks. The pluton was exposed fairly quickly after intrusion, as documented by overlying alluvial deposits (Tsmy) that are eroded from the pluton and interbedded with a 13.27 Ma basalt flow (Tdmm; see descriptions of both units below).

\section{Mount Davis Volcanics}

The Mount Davis Volcanics were named by Longwell (1963) for outcrops near Mount Davis, Arizona (approximately $50 \mathrm{~km}$ south of Hoover Dam), and were further described by Anderson (1971) and Anderson and others (1972). The Mount Davis includes volcanic rocks ranging in composition from rhyolite to basalt, interbedded with clastic and volcaniclastic deposits. For this report, we divided the Mount Davis into lower, middle, and upper parts. The units that make up the lower part are only exposed in the Eldorado Mountains (Felger and others, 2014) and are not discussed further here. Rocks of the middle and upper Mount Davis Volcanics are widely exposed on both sides of Black Canyon, and unconformably overlie the Patsy Mine Volcanics. Middle Mount Davis rocks may be intruded by or coeval with the Boulder City pluton, whereas upper Mount Davis rocks unconformably overlie it. The volcanic stratigraphy for the Mount Davis Volcanics in the Hoover Dam area was defined by Mills (1994), and includes (from base to top) the Dam conglomerate (Tdc), Tuff of Hoover Dam (Thd), Switchyard basaltic andesite (included in Tdmm), Sugarloaf and Black Canyon dacites (Tdru), and Kingman Wash basaltic andesite (included in Tdmu); clastic and volcaniclastic rocks (Tds) are interbedded throughout the sequence. We assigned units that pre-date the Sugarloaf dacite to the middle Mount Davis and the Sugarloaf dacite and units that post-date it to the upper Mount Davis.

The Dam conglomerate (Tdc; Mills, 1994; Dam breccia of Ransome, Bureau of Reclamation, 1950) unconformably overlies the Patsy Mine Volcanics near Hoover Dam, and is mostly a matrix to clast-supported conglomerate composed of angular-to subrounded clasts of Patsy Mine andesite and granite porphyry that were identified as Boulder City pluton by Anderson (1978) and Mills (1994). In some places, the conglomerate grades laterally into red volcanic sandstone (Bureau of Reclamation, 1950). Mills (1994) mapped the Dam conglomerate at the base of the Tuff of Hoover Dam; however, mapping for this report places it lower, at the base of an andesitic flow sequence between Sugarloaf and Palm Tree Canyons that was previously mapped as Patsy Mine Volcanics by Anderson (1978) and Mills (1994). Mapping indicates an angular unconformity, marked by discontinuous thin sandstone and conglomerate beds inferred to be Dam conglomerate at the base of the andesite flow sequence. We included the andesitic flow sequence with the middle part of the Mount Davis Volcanics, based on field mapping and geochronologic data, rather than the Patsy Mine Volcanics because a basaltic andesite flow just above the sandstone and conglomerate beds yielded an ${ }^{40} \mathrm{Ar} /{ }^{39} \mathrm{Ar}$ age of $14.19 \pm 0.03 \mathrm{Ma}$ (Mills, 1994). This date is more consistent with the age range of Mount Davis than with Patsy Mine Volcanics. The basaltic andesite flow overlies the Dam conglomerate and therefore the granite clasts in the conglomerate must be older than the zircon age of the Boulder City pluton. They were derived from either an older phase of the Boulder City pluton or a different pluton.

The andesitic flow sequence is overlain by the Tuff of Hoover Dam (Thd; Latite Flow Breccia of Ransome, Bureau of Reclamation, 1950), with a ${ }^{40} \mathrm{Ar} /{ }^{39} \mathrm{Ar}$ eruptive age of $13.90 \pm 0.01 \mathrm{Ma}$ (Mills, 1994). The tuff is a lithic ash-flow tuff sequence, moderately welded with some poorly welded zones that tend to form slopes in otherwise cliffy outcrop. It is very vuggy and contains varying phenocryst content of plagioclase and biotite. Lithic fragments are common to abundant, and are mostly Patsy Mine Volcanics and possibly Wilson Ridge pluton (Mills, 1994). The tuff exhibits widespread evidence of multiple cycles of fracture and healing that rendered the tuff less permeable (R.E. Anderson, written commun., 2011; Angelier and others, 1985). It is highly fractured and cut by many faults but is described as "even stronger and more impervious 
that the Dam Breccia of Ransome" (Bureau of Reclamation Report, 1950, p. 168). The faults are described as quite tight and mostly healed with very little crush (gouge) zone (Angelier and others, 1985). Pupfish spring (PfS, fig. 2) discharges as seeps along fractures and cooling horizons within the tuff, indicating some limited groundwater flow. The tuff is thickest to the north from Hoover Dam to Promontory Point, thins rapidly south of the dam, and is traceable as far as Arizona Hot Spring Canyon; it has not been identified on the western side of Black Canyon. The source of the tuff is unknown; Mills (1985) suggested it could be a northwest-southeast trending sag or graben caldera formed during extension.

The Switchyard basaltic andesite of Mills (1994; Tdmm) unconformably overlies the Tuff of Hoover Dam (Thd), and is in turn overlain by the Sugarloaf dacite of Mills (1994; Tdru), which has an ${ }^{40} \mathrm{Ar} /{ }^{39} \mathrm{Ar}$ age of $13.11 \pm 0.02 \mathrm{Ma}$ (Faulds and others, 1999). West of Black Canyon, the basalt that rests on clastic sediments or unconformably on the Boulder City pluton was sampled by R.E. Anderson (written commun., 2007) and analyzed for this study. It yielded an ${ }^{40} \mathrm{Ar}{ }^{39} \mathrm{Ar}$ age of $13.27 \pm 0.03 \mathrm{Ma}$ (Felger and others, 2014) and may be equivalent to the Switchyard basaltic andesite.

Dacite flows and domes at Bighorn Sheep Canyon are more faulted and tilted than the Sugarloaf and younger dacites to the north and are included in the middle Mount Davis (Tdrm), as is a small plug north of White Rock Canyon. Undifferentiated mafic flows (Tdmm) that overlie the dacite at Bighorn Sheep Canyon (Tdrm) are also included in the middle Mount Davis and underlie the Lava of No Name Mesa of Ekren and Anderson (1996; Tdru) on the western side of Black Canyon.

The Sugarloaf dacite of Mills (1994; 13.11 $\pm 0.02 \mathrm{Ma}$, ${ }^{40} \mathrm{Ar} /{ }^{39} \mathrm{Ar}$ ), Black Canyon dacite of Mills (1994), Lava of No Name Mesa of Ekren and Anderson (1996) (13.10 $\pm 0.10 \mathrm{Ma}$; Gans and Bohrson, 1998), and unnamed dacite flows and domes on the eastern side of Black Canyon south of Palm Tree Canyon form upper massive flows that cap many ridges and mesas on both sides of the canyon, and are part of the upper Mount Davis Volcanics (Tdru). West of the river, the dacites are deposited on the Boulder City pluton and mafic lavas of the middle Mount Davis. The dacite flows are typically massive cliff forming biotite and hornblende bearing dacite flows and flow breccias, generally with a pale yellow zeolitized slope forming the lower part. Locally, they include a basal vitrophyre. Associated with many of the flows and domes are linear dacite dikes and irregularly shaped massive intrusions. A large intrusion on the northern side of Goldstrike Canyon (fig. 2) is the inferred source of the Sugarloaf dacite (Mills, 1994).

The uppermost volcanic unit in the Mount Davis near Hoover Dam is the Kingman Wash Road basaltic andesite (Tdmu) dated at $12.66 \pm 0.1 \mathrm{Ma}\left({ }^{40} \mathrm{Ar} /{ }^{39} \mathrm{Ar}\right.$; Mills, 1994; sample reported as $12.57 \pm 0.03 \mathrm{Ma}$ in Faulds and others, 1999). Clastic and volcaniclastic sediments (Tds) interbedded throughout the Mount Davis include red sandstone and conglomerate, white and pale yellow glassy tuffaceous sedimentary rocks, massive airfall tuff, and lithic tuffs associated with the Tuff of Hoover Dam or dacitic rocks.

\section{Local Basin-Fill Deposits}

Basin-fill sedimentary rocks (pl. 1, fig. 2) are divided into a younger coarse clastic unit (Tsy) and an intermediate-age basin-fill sequence (Tsmy and Tsmo). Older sedimentary rocks shown on the regional geologic map and cross sections (Tso on pl. 1) are not exposed within the study area. The younger sedimentary rocks are mostly clastic units shed from nearby ranges; on the western side of Wilson Ridge, they are interlayered with young basaltic rocks (Tby).

The intermediate-age sequence is subdivided into younger (Tsmy) and older (Tsmo), east and mostly west of the Colorado River, respectively. East of Black Canyon and south of Hoover Dam, coarse clastic alluvial fan sediments intertongue with and overlie the Kingman Wash Road basaltic andesite. An ${ }^{40} \mathrm{Ar} /{ }^{39} \mathrm{Ar}$ age of $11.72 \pm 0.06 \mathrm{Ma}$ on sanidine from a tuff near the base of the younger sediments was reported by Williams (2003), who measured more than $600 \mathrm{~m}$ thickness for the unit. These rocks were originally called the Muddy Creek Formation by Anderson $(1977,1978)$ but were since redefined by Mills (1994) and Williams (2003) as the Black Mountain conglomerate; in this study, we map them as Tsmy (fig. 2). South and east of Arizona Hot Spring (AHS, fig. 2), a series of landslide masses of Proterozoic crystalline rock (Tsmm), presumably derived from steep fault fronts to the east (Longwell, 1963), overlie Patsy Mine and Mount Davis Volcanics and the Tsmy unit. Southward, the landslide masses overlie and intertongue with coarse alluvial fan conglomerates that in turn intertongue farther south with fine-grained clastic rocks, and minor gypsum and limestone east of Willow Beach. Locally, the gypsum is manganese-rich. These rocks are tilted gently eastward and are probably no more than a few hundreds of meters thick, based on the depth-to-bedrock model by Langenheim and Schmidt (1996) and Langenheim and others (2010). Collectively, these sediments were deposited in the Black Mountain Basin (Williams, 2003). This is a syntectonic basin filled by sediment derived from the east during uplift and faulting of Wilson Ridge. The western edge of the basin is unknown but likely was a bedrock divide where Black Canyon is today, separating the Black Mountain Basin from an older basin represented by the older intermediate sedimentary rocks (Tsmo) mostly west of Black Canyon.

Older intermediate-age sedimentary rocks (Tsmo), exposed west of Black Canyon and south of Boulder City, include a few tens of meters of coarse clastic rocks deposited against the Boulder City pluton that thicken slightly southward and become interbedded with fine-grained clastic rocks and local thin beds of gypsum and manganiferous gypsum. The fine-grained rocks are no more than 100-200 m thick in the area south of Boulder City, based on the depth-to-bedrock model of Langenheim and others (2010), but they may thicken southward in the subsurface of Eldorado Valley. The coarse clastic rocks are hematized where they are in contact with the 
Boulder City pluton, and sandstone exposed near the Rifle Range south of Boulder City is locally impregnated with manganese. The rocks underlie the middle Mount Davis basalt flow dated at $13.27 \pm 0.03 \mathrm{Ma}$ (Felger and others, 2014). Unit Tsmo also is mapped west of Malpais Flattop Mesa, where a basalt flow with an ${ }^{40} \mathrm{Ar} /{ }^{39} \mathrm{Ar}$ age of $12.73 \pm 0.3 \mathrm{Ma}$ (Faulds and others, 1999) separates it from overlying Tsmy; the Tsmo deposits are the "pre-Tml" unit of Williams (2003).

\section{Geologic Controls on Spring Discharge}

This section provides a general overview of geologic features that influence the locations of spring and seep discharge in tributary canyons to Black Canyon. A systematic field study in those canyons included kinematic analysis of the faults. Most of these tributary canyons are not formally named; we use informal names based on hiking guides or name the canyons after the hot springs. Canyons, springs, and faults discussed in this section are shown in figure $2 B$. In the following discussions, a distinction is made between horizontal axis tilting of fault blocks along normal faults, and vertical axis rotation of blocks along strike-slip faults.

The largest faults in the central and northern Eldorado Mountains strike northerly and have normal-sense displacement. North of Hoover Dam, strike-slip faults with displacement vectors that mimic the LMFS and LVVSZ are common, that is, northeast-striking left-lateral faults and northwest-striking right-lateral faults. Near Hoover Dam, mostly northeasttilted fault blocks are cut by northwest-striking, southwest-side down faults, and those blocks and faults are cut by younger faults with more northerly strikes. To the south, faults strike northerly and dip both east and west, but at Bighorn Sheep canyon faults dip west and blocks are mostly east-tilted.

\section{Geology and Fault Data for Tributary Canyons}

Fault data, including strike, dip, rake, and sense of slip, were collected within major tributary canyons of Black Canyon with thermal features (fig. 2). In this section, we summarize geologic observations and fault data for the tributary canyons. A kinematic analysis of fault data is presented in appendix 1 and summarized in next section, "Kinematic Analysis of Fault Data." Geologic units mentioned in the text are keyed to the geologic map in figure 2.

\section{Palm Tree Canyon}

Palm Tree Canyon is about $2 \mathrm{~km}$ south of Hoover Dam on the eastern side of the Colorado River. Springs in the canyon are located along a large southeast-striking, southwest-dipping, right-lateral fault, herein referred to as the Palm Tree Fault (fig. 2). The Palm Tree Fault controls the strike of the canyon and multiple fault surfaces are exposed along the canyon walls.

Most seepage from Palm Tree Hot Spring (PTS, fig. 2) discharges from modern alluvial deposits on the canyon floor, but is likely sourced from the main trace of the Palm Tree
Fault because small seeps and evidence of flowing water, such as evaporite precipitates, occur on surfaces of the main fault along the canyon walls (fig. 4). In addition, some seeps and small orifices discharge from fractures and, less commonly, the matrix of the Patsy Mine andesitic breccias (Tpl) north of the fault zone and below the contact with the middle Mount Davis andesitic flow sequence (Tdmm; fig. 5A). The contact here is marked by red volcanic sandstone of the Dam conglomerate (Tdc). Layered volcanic breccias of the Patsy Mine strike north and dip east; and fractures, bedding planes, and matrix porosity may provide pathways for groundwater to move as much as $100 \mathrm{~m}$ laterally along the volcanic units (based on vegetation visible in 2006 Quickbird satellite imagery (DigitalGlobe, 2006). The Palm Tree Fault continues northwest across the river into the Boulder City pluton (Tibu) and controls the strike of lower Goldstrike Canyon. Dacite dikes (Tdri) can be seen intruded along the fault zone across the river west from Palm Spring (fig. $5 B$ ).

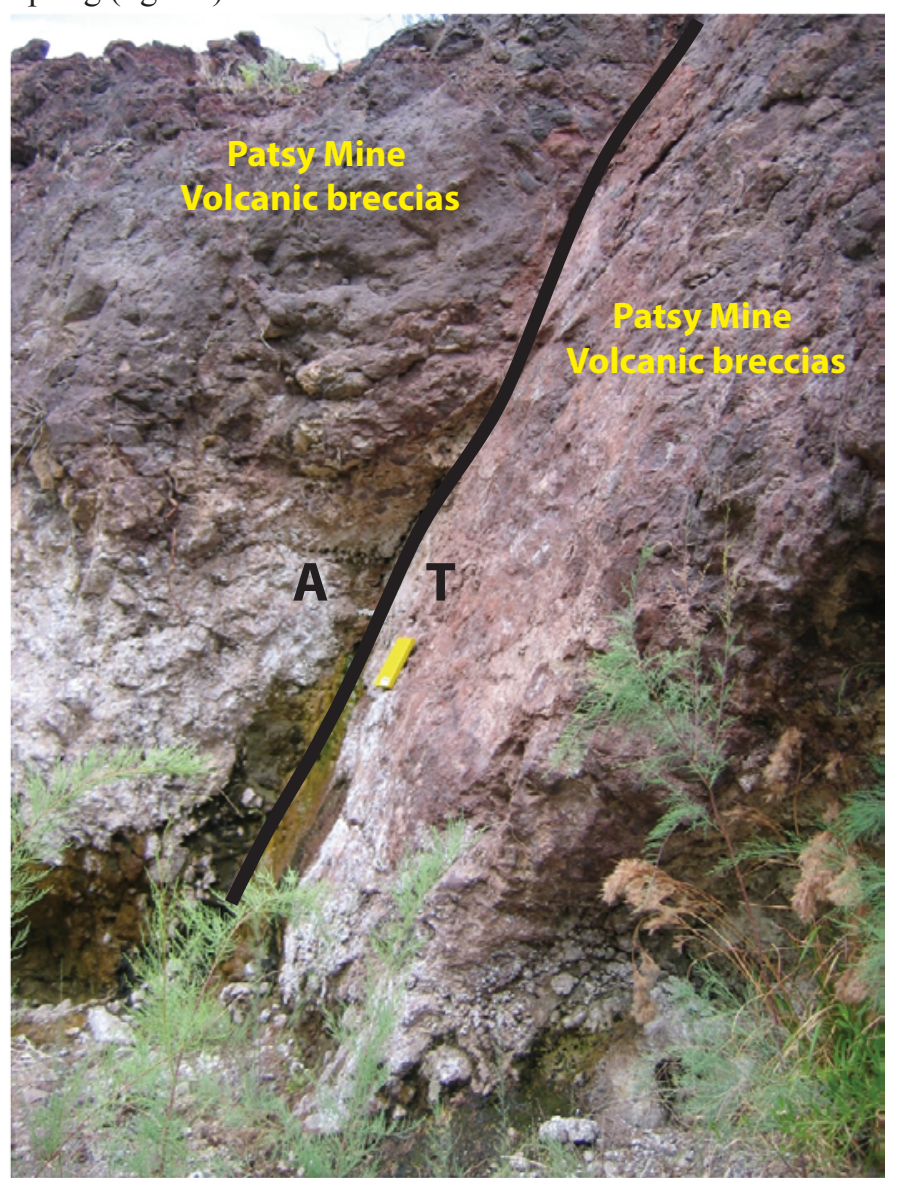

Figure 4. Photograph of view to the northwest showing spring discharging from a splay of the Palm Tree Fault in Palm Tree Canyon. The yellow notebook (approximately 20 centimeters long) is resting parallel to the fault plane on the foot-wall block and the slightly curved surfaces at and below the book are mullions recording strike-slip. Notice the abundant evaporite precipitates (white coatings) on both the foot-wall and the hanging-

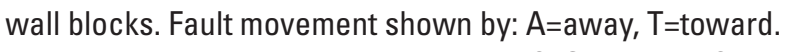
Photograph taken by Z. W. Anderson, U.S. Geological Survey, April 20, 2009. 

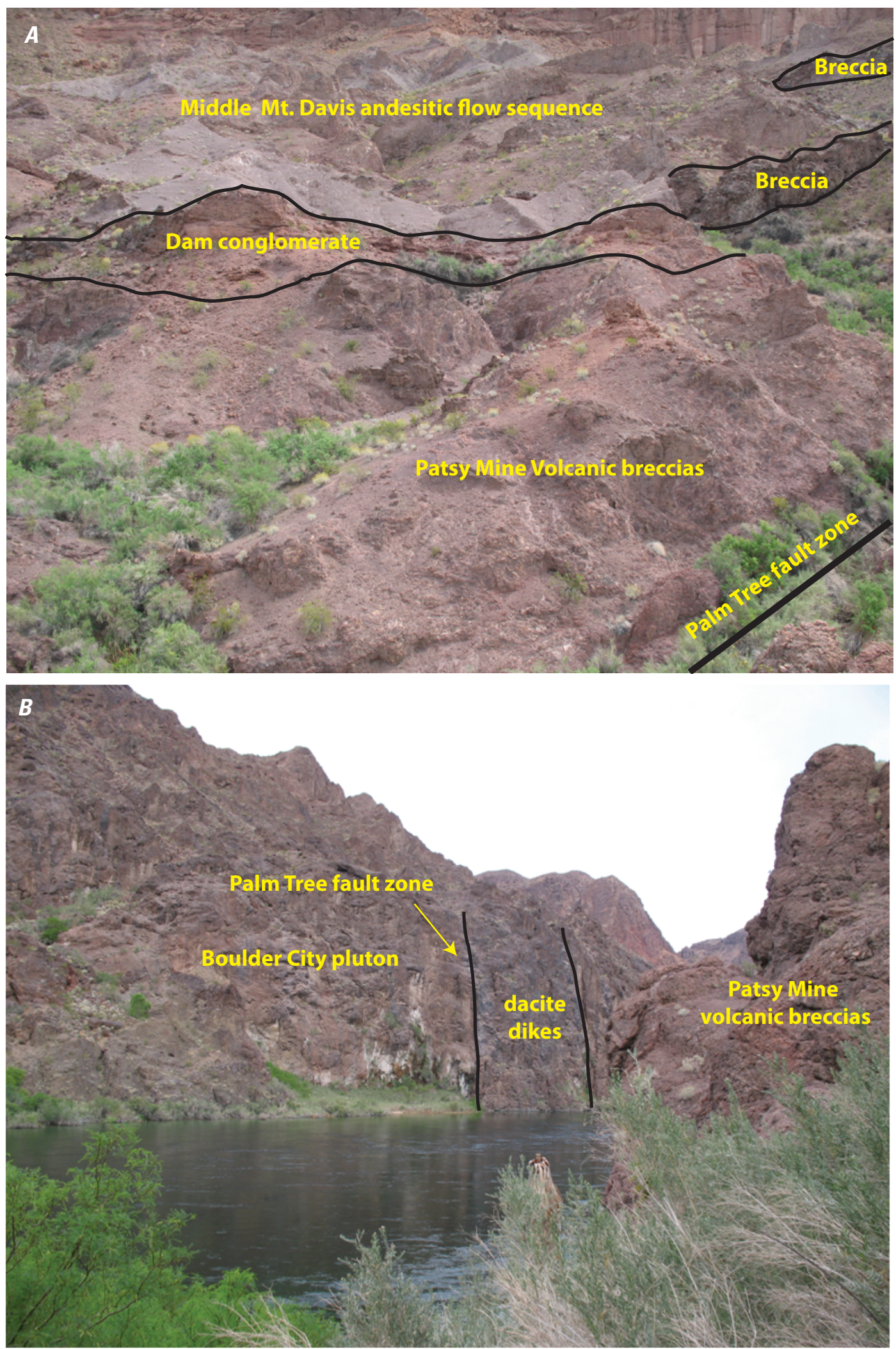

Figure 5. Photographs showing $(A)$ spring seepage in Palm Tree Canyon, marked by green vegetation, in Patsy Mine volcanic breccias and along base of Dam conglomerate. View is to east-northeast across Palm Tree Fault Zone (lower right of photograph), and (B) view from mouth of Palm Tree Canyon, looking across the Colorado River to the northwest. Vertical dacite dike is intruded along a strand of the Palm Tree Fault Zone. Note seepage in Boulder City pluton adjacent to the fault and dike, marked by white evaporite precipitates. Both photographs taken by L.S. Beard, U.S. Geological Survey, April 16, 2009. 
$\boldsymbol{A}$

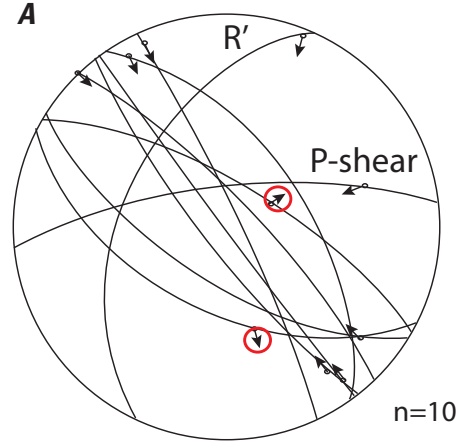

B

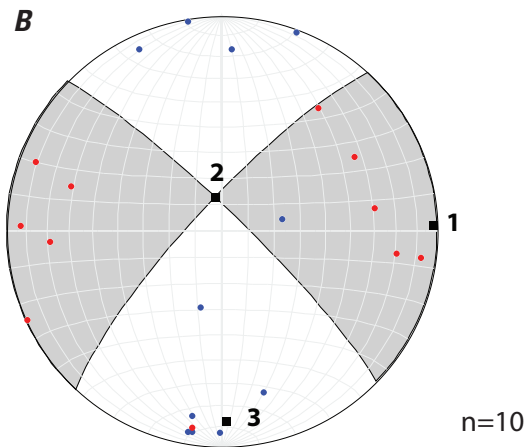

-Fault Plane Solution -

Fault Strike Dip Trend Plunge Slip Sense

$\begin{array}{llllll}\text { 1. } & 133.9 & 67.5 & 052.3 & 14.7 & \mathrm{~N}\end{array}$

2. $\quad 037.7 \quad 75.3$

P-axis: $354.3,26.7 ; \quad$ T-axis: $087.0,05.3$
- Linked Bingham Analysis -

Axis Eigenvalue Trend Plunge

$\begin{array}{llll}1 . & 0.3247 & 088.2, & 02.2\end{array}$

2. $0.0185 \quad 348.9, \quad 76.9$

3. $0.3062 \quad 178.7,12.9$

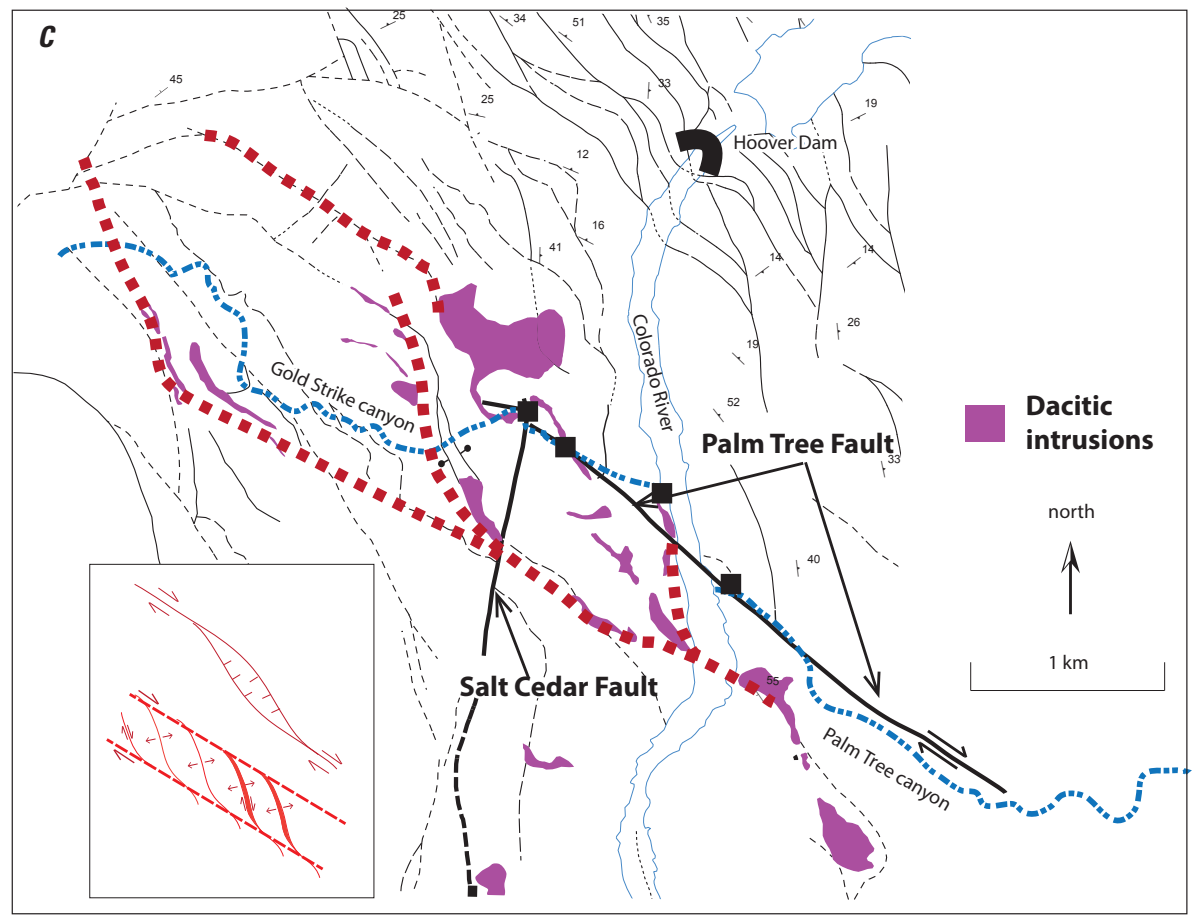

Figure 6. $A$, Equal-area stereonet plots of all faults measured in Palm Tree Canyon. Arrows on fault planes are trend and plunge of fault striae and point in the direction of hanging-wall movement. The northwest-striking faults are part of the main right-lateral strike-slip fault that controls springs within the canyon. The southwest-striking fault is most likely an antithetic secondary structure $\left(R^{\prime}\right)$ to the main fault. The fault that strikes west-east and dips north is a synthetic secondary structure to the main fault (P-shear). The normal faults (faults with red circles) are within the damage zone of the main southeast-striking, right-lateral strike-slip fault and may be secondary structures of the main fault. $B$, Kinematic fault-plane solution derived from ten faults measured within Palm Tree Canyon. Northwest- and southwest-striking nodal planes separate shortening (shaded) and extensional quadrants containing shortening (P) axes (red circles) and extension (T) axes (blue squares) of the faults. The $\mathrm{P}$ and $\mathrm{T}$ axes outside of their respective shortening and extensional quadrants are the two red-circled faults on $A$. Linked Bingham axes (black squares) indicate (1) a subhorizontal, east-directed extension direction, (2) a subvertical intermediate axis, and (3) roughly a southerly subhorizontal shortening axis. See Marrett and Allmendinger (1990) and appendix 1 for explanation of kinematic faultplane solutions. $C$, Schematic diagram of right-sense fault step-over of Palm Tree Fault Zone. The red lines represent the best estimate for the boundaries of the step-over, defined by faults and $S$ shapes of dike intrusions. The dashed red line is the maximum possible southern extent of the step-over; however, field data and map patterns are more ambiguous in this area. Black lines represent mapped faults. Purple lines and polygons represent dacite intrusions that accommodate extension in the step-over area. Note the two normal to oblique faults west of Salt Cedar Fault Zone that are intruded by a dacite body. Upper diagram of inset figure shows idealized pull-apart structures along a releasing bend along a single strike-slip fault. Lower diagram shows expected orientation of en echelon extensional fractures within a right-lateral shear zone. 
Based on the map pattern of fault distributions and the sigmoid shape of dacite dikes (fig. 6C), Palm Tree Fault is a northwest-striking right-lateral fault system that steps right from about the mouth of Palm Tree Canyon northwestward for approximately $2.5 \mathrm{~km}$ (fig. 6; Beard and others, 2011a). The right step is a releasing bend, creating local extensional strain within the step-over zone that is accommodated by at least two normal faults and intrusion of dacite dikes, as well as a large plug or dome feature north of Goldstrike Canyon. The map pattern indicates that to the northwest, the zone of right shear turns abruptly southwest, most likely rotated counterclockwise by strands of the LMFS (fig. $2 B$ ).

\section{Goldstrike Canyon}

Goldstrike Canyon is about $2 \mathrm{~km}$ southwest of Hoover Dam on the western side of Black Canyon (fig. 2). The Palm Tree Fault mostly parallels the canyon about $0.8 \mathrm{~km}$ from the canyon mouth where the canyon bends sharply north (figs. 2 and $6 C$ ). Multiple seeps and hanging gardens below the bend discharge from en echelon southeast-striking, southwestdipping faults of the Palm Tree Fault Zone and from highly brecciated plutonic rocks adjacent to the faults and dacite dikes (fig. 7). Multiple northwest-striking dacite dikes (Trdi) intrude the Boulder City pluton (Tibu) within the zone of right-lateral step-over along strands of the Palm Tree Fault; the dikes are visible along Goldstrike Canyon and also influence the location of the seeps and hanging gardens.

The sharp north bend in the canyon coincides with the trace of a large northerly-striking fault, which is at the northern end of a broad fault zone that is traceable southward at least to Salt Cedar Canyon and is herein called the Salt Cedar Fault Zone (fig. 6C; equivalent to Jeep Pass Fault of Longwell, 1963). Across this fault to the west, the Palm Tree Fault is offset about $100 \mathrm{~m}$ in a right-lateral sense (figs. $8 A$ and $8 B$ ) and traceable for a short distance farther northwest. Nevada Hot Spring (NHS, fig. 2), the uppermost discharge area in Goldstrike Canyon, emanates from the termination of Palm Tree Fault downstream to its intersection with the Salt Cedar Fault Zone. This area shows evidence of abundant

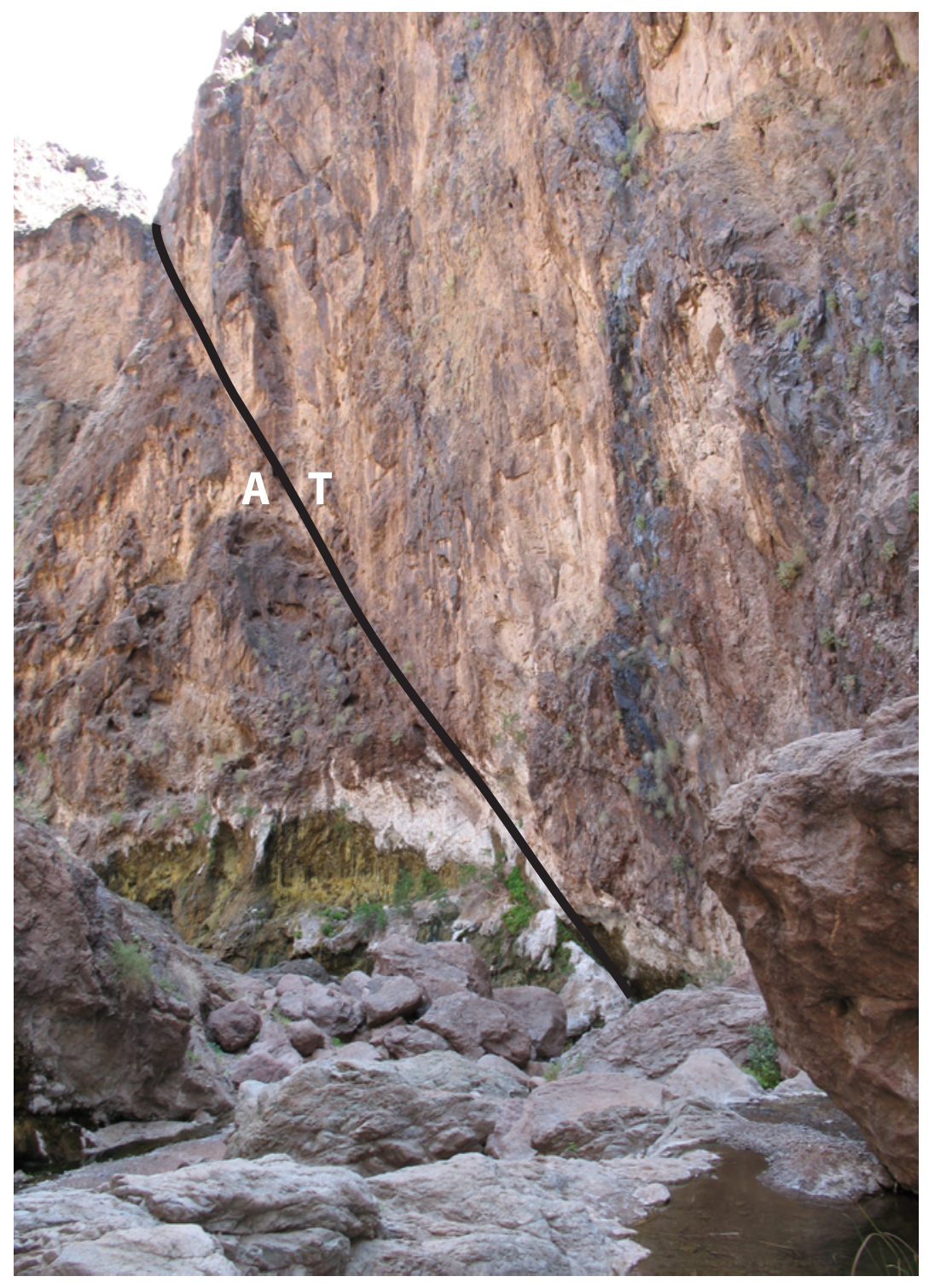

Figure 7. Photograph showing oblique view to southeast of Palm Tree Fault in lower Goldstrike Canyon; displacement on fault shown by: $\mathrm{T}=$ side moving toward view, $A=$ side moving away. Spring discharge occurs along fault plane and as weeping walls in the footwall, as seen by salt encrustations and vegetation. Weeping walls typically occur in on the northeast side of the Palm Tree Fault Zone. Rocks are Boulder City pluton. Photograph taken by L.S. Beard, U.S. Geological Survey, April 16, 2009. 

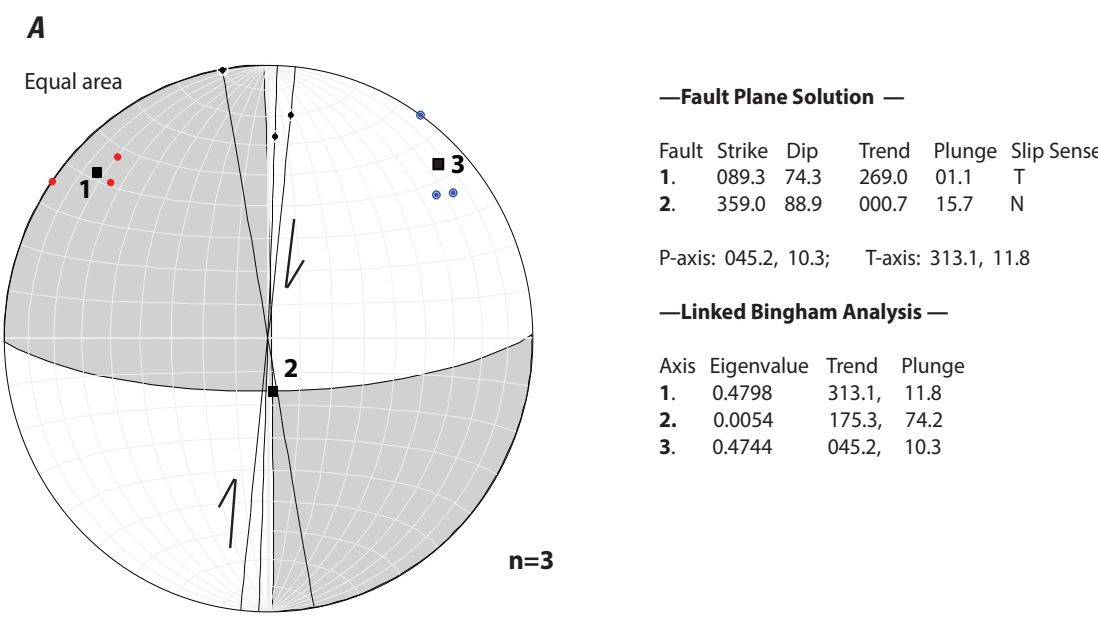

-Linked Bingham Analysis -

Axis Eigenvalue Trend Plunge

1. $0.4798 \quad 313.1, \quad 11.8$

2. $0.0054 \quad 175.3,74.2$

3. $0.4744 \quad 045.2, \quad 10.3$
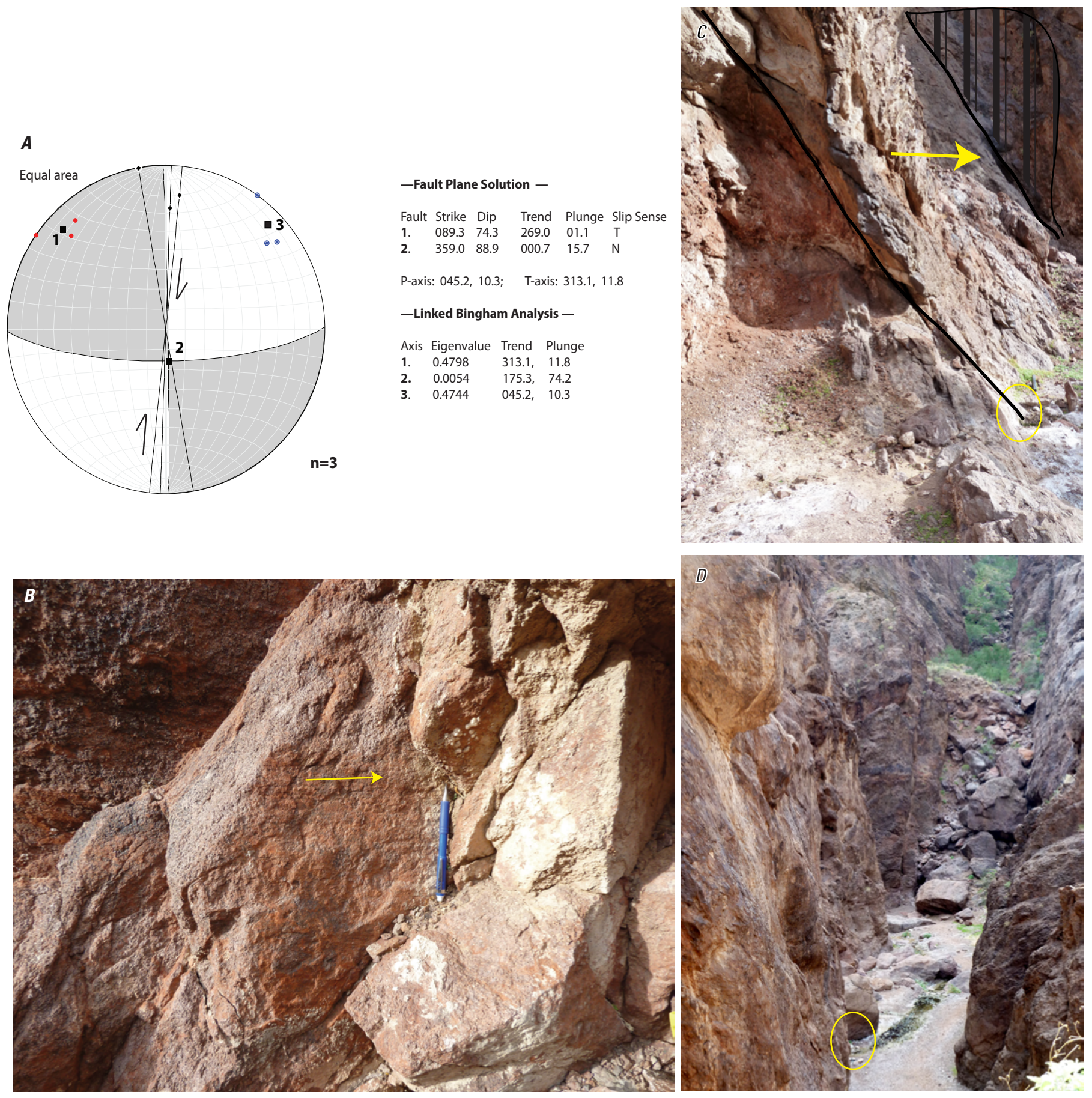

Figure 8. A, Plot of fault planes and striae from the northern end of Salt Cedar Fault System, over kinematic fault-plane solution derived from the same faults. Solution indicates right-lateral slip on a north-south plane. North- and west-striking nodal planes separate shortening (shaded) and extensional quadrants defined by shortening (P) axes (red circles) and extension (T) axes (blue squares) of the faults. $B$, Photograph showing horizontal striae on a segment of the Salt Cedar Fault, measured on north side of Goldstrike Canyon. C, Photograph showing view to east of strand of Palm Tree Fault Zone west of Salt Cedar Fault in Goldstrike Canyon, in vicinity of uppermost man-made thermal pools of Nevada Hot Springs. Ellipse marks site of spring discharge into the wash at base of fault exposure. Pattern in background marks fault surface of Salt Cedar Fault, which strikes nearly orthogonal to the Palm Tree Fault. View in $D$ is parallel to arrow. $D$, Photograph showing view to south along Salt Cedar Fault. Ellipse marks site of spring discharge from fault zone on left side of photograph. The fault extends south of the wash, forming steep-walled cleft, partially filled with coarse unconsolidated rubble. Surfaces with right-lateral striae $(B)$ are on fault plane directly behind photographer. All photographs taken by L.S. Beard, U.S. Geological Survey, December 10, 2010. 
spring discharge, including a carbonate spring mound, gypsiferous encrustations, and human-made hot spring pools, but was mostly dry in the summer of 2010 . However, during a visit in late 2010, two areas of flowing thermal waters were clearly discharging from the two faults: a smaller flow from the western end of the Palm Tree Fault where it intersects the wash, and a larger flow from the eastern wall of the canyon along the Salt Cedar Fault Zone (fig. $8 C$ and $D$ ). The larger flow formed a continuous stream down channel and was the main water source for downstream human-constructed hot spring pools in late 2010 .

\section{Boy Scout Canyon}

Boy Scout Canyon is on the western side of the river about $3.6 \mathrm{~km}$ south of Hoover Dam (fig. 2). Faults are sparse along the lower reach of the canyon; instead, seeps and springs along the canyon discharge mostly from a northeast-striking fracture set within the Boulder City pluton that controls a northeastern trending reach of the canyon (fig. 9). The fracture set is likely related to the emplacement and/or cooling history of the pluton because it parallels and changes strike with the margin of the pluton. The uppermost discharge site of thermal waters within Boy Scout Canyon is along the contact between the Boulder City pluton and a large dacite body (BSS, fig. 2).

The dacite (Tdri) is parallel to and intrudes along a north-south segment of the Salt Cedar Fault Zone. The faulted pluton is capped by upper Mount Davis volcaniclastic sediments (Tds) and dacite flows (Tdru) that are most likely sourced, in part, from the dacite intrusion and are significantly less faulted. Pohlmann and others (1998) suggested the overlying volcaniclastic sediments may form barriers to lateral and upward flow along the fault; however, this seems unlikely as the base of the sediments is about 150-200 m higher than the highest elevation seeps. We interpreted that thermal groundwaters likely move vertically along the Salt Cedar Fault adjacent to the dacite intrusion and move laterally down gradient from the

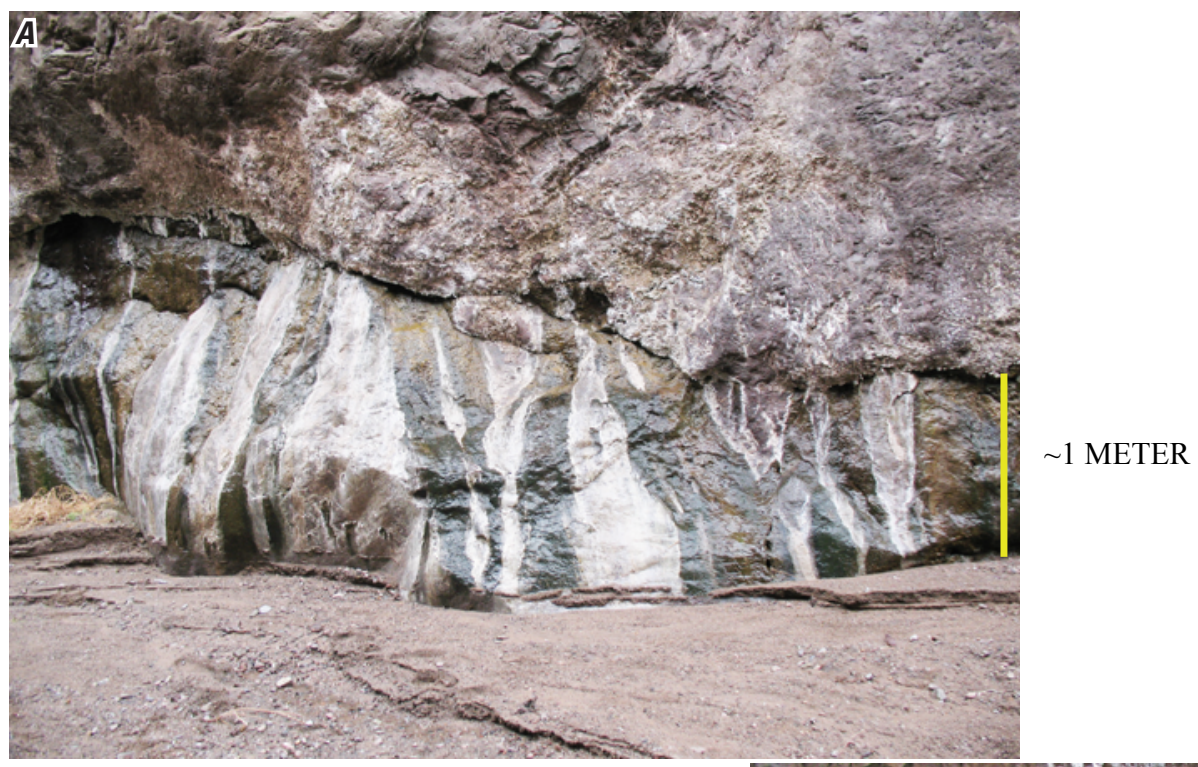

Figure 9. A, Photograph of seepage along fracture in Boy Scout Canyon, marked by white stains. Fracture parallels wash wall and dips toward viewer. $B$, View showing one of several faults and fractures near the mouth of Boy Scout Canyon. Both photographs taken by M. Truini, U.S. Geological Survey, December 6, 2007. $C$, Stereonet plot of fractures measured near seeps, showing average dip of 43 degrees to the southeast.

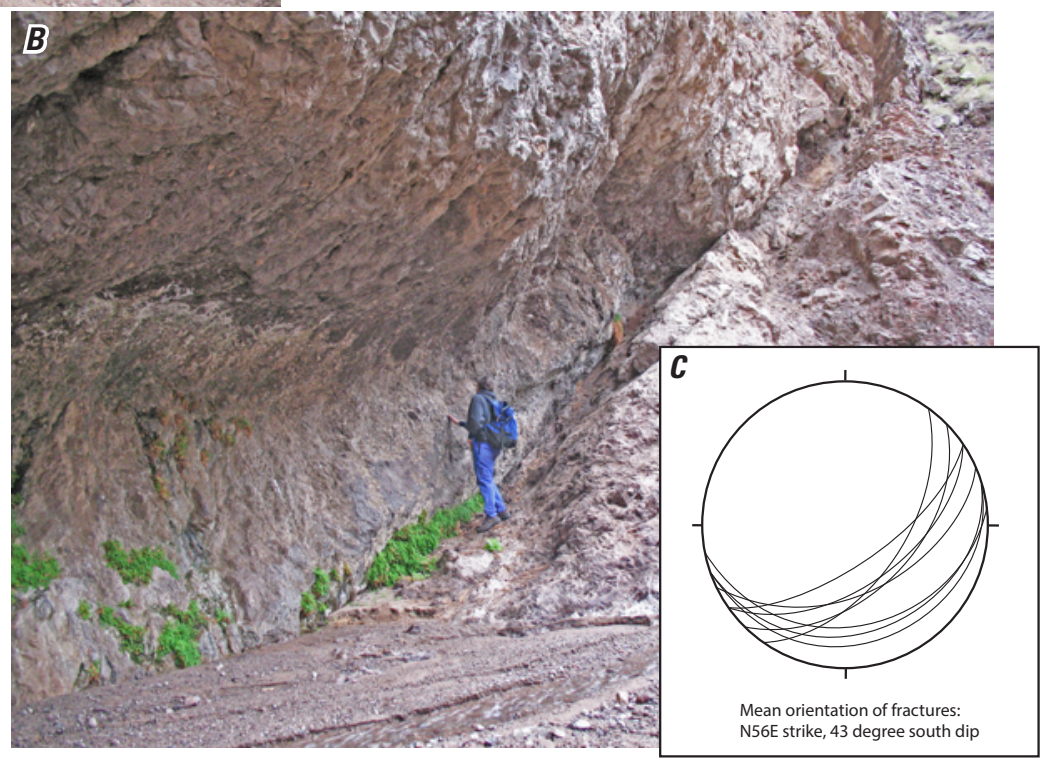


fault eastward into the Boulder City pluton along the fracture system, discharging at numerous places in the canyon.

\section{Salt Cedar Canyon}

Salt Cedar Canyon is on the western side of the river about $5.4 \mathrm{~km}$ south of Hoover Dam (fig. 2). The canyon mostly follows the northeast strike of south-tilted Patsy Mine Volcanics rocks (Tpl). The volcanic rocks are intruded by numerous north- to northwest-striking, steeply dipping dacitic dikes, locally cut by nearly horizontal dikes. Like Boy Scout Canyon, faults are sparse in the canyon; instead, springs and seeps discharge from numerous sites along the canyon and its tributaries, usually in the lower $10 \mathrm{~m}$ of the canyon walls and at contacts between volcanic units or at the junction of contacts and dikes. Quickbird imagery from 2006 (DigitalGlobe, 2006) shows extensive vegetation in the main Salt Cedar Canyon and its tributaries (red areas in fig. 10A). The vegetation indicates that the highest elevation springs are at the head of the canyon, where the volcanic rocks are in fault contact with Proterozoic basement rocks (Xgn). This fault is mapped as part of the Salt Cedar Fault Zone (Beard and others, 2011a) and is intruded by dacite (Tdri) forming a 30 to 100 meter wide dike (figs. $10 A$ and $10 B$ ). Like Boy Scout Canyon, the fault and dike are overlain by upper Mount Davis volcaniclastic sediments (Tds) and dacite flow (Tdru) that may serve as low-permeability barriers to upward flow in the fault zone; however, they also are about 100-200 $\mathrm{m}$ above the highest discharge elevation. A steady stream of thermal water was observed coming from the fault and from the margins of the dacite intrusion during a field visit in April 2009 (fig. 10C).

\section{Arizona Hot Spring Canyon and White Rock Canyon}

Arizona Hot Spring Canyon and White Rock Canyon (Arizona White Rock graben or AZWR), on the eastern side of the river about $6 \mathrm{~km}$ south of Hoover Dam (fig. 2), are described together because they are in close proximity and many structures are linked between the canyons (fig. 11A). Faults measured in AZWR Canyons are described in more detail in appendix 1 and in the section entitled "Kinematic Analysis of Fault Data." The dominant strike of faults in the area is northwest to north with a smaller population that strike north to north-northeast. The canyons are mostly in altered andesite and minor rhyolite flows and flow-breccias of the Patsy Mine Volcanics (Tpl). A north-northwest-striking half-graben to graben (AZWR graben, fig. 2) exposed in the canyons contains the Tuff of Hoover Dam (Thd) overlain by andesite of the middle part (Tdmm) and volcaniclastic sediments (Tds) and dacite of the upper part (Tdru) of the Mount Davis Volcanics. A large north-northwest striking oblique normal fault bounds the eastern side of the graben. The western side of the graben is faulted in White Rock Canyon, but the fault terminates southward and is replaced by an angular unconformity between Patsy Mine and Mount Davis rocks in Arizona Hot Spring Canyon. Rocks within the graben are dominantly faulted by north- to northeast-striking, high-rake faults. Some faults within the graben display upward-diminishing offset and do not cut the upper most middle Mount Davis volcaniclastic sediments and dacite.

Two distinct episodes of faulting occurred in the AZWR graben area, and are discussed in more detail in the section entitled "Kinematic Analysis of Fault Data". The older episode is characterized by northwest striking, high- and lowrake faults that are restricted to the Patsy Mine and middle Mount Davis Volcanics. The younger episode is characterized by north-northeast striking high-rake faults that cut the upper Mount Davis Volcanics.

Spring discharge in both canyons is confined to Patsy Mine volcanic rocks (Tpl) below the unconformity with Mount Davis rocks and west of the AZWR graben. The minor seeps in the lower part of White Rock Canyon discharge just below a westerly-striking, north-dipping, lowangle fault with porous volcanic breccias and volcaniclastic sediments in the footwall, and dense potassic-altered volcanic rocks in the hanging wall (figs. $11 B$ and $11 C$ ). White Rock Canyon seeps are within the northeast-striking, moderately south dipping Patsy Mine volcanic rocks, equivalent to those at the seeps and springs in Salt Cedar Canyon across the river to the west (fig. 2).

The major spring discharge in Arizona Hot Spring Canyon is along the contact between dacite dike and flow breccia units of the Patsy Mine Volcanics. The dike is intruded along a north-northwest-striking fault. Pohlmann and others (1998) indicate that the springs are controlled by the intersection of the north- northwest striking, strike-slip fault and a northsouth striking, normal fault. We infer that the dike forms a vertical barrier to lateral flow at the fault intersection, and results in vertical flow of thermal groundwater to the surface. The north-south fault may be a segment of a larger fault system, herein called the White Rock Fault (fig. 2).

\section{Bighorn Sheep Canyon}

Bighorn Sheep Canyon is about $8 \mathrm{~km}$ south of Hoover Dam on the western side of the river (fig. 2). The canyon is controlled by a large west-dipping, oblique-slip fault, named the Bighorn Fault (fig. 2), that strikes dominantly north but makes an arcuate bend to the southwest through Bighorn Sheep Canyon. The fault displaces Patsy Mine volcanic rocks $(\mathrm{Tpl})$, overlain by dacite flows tentatively mapped as middle Mount Davis (Tdrm), down to the west and north against the Patsy Mine on the south and east (fig. 12A). A series of high-angle normal- to oblique-slip faults cut the hanging-wall rocks and end against the Bighorn Fault (fig. 12B). Most of the thermal waters, including Bighorn Sheep and Nevada Falls springs (BS and NFS, fig. 2), discharge from springs and seeps along the Bighorn Fault or from rocks adjacent to it. Many exposures of the fault plane throughout the lower half of the canyon show evidence of evaporite precipitation. Fault surfaces along the more westerly trace of the fault have two sets of striae, indicating both strike-slip and dip-slip (fig. 

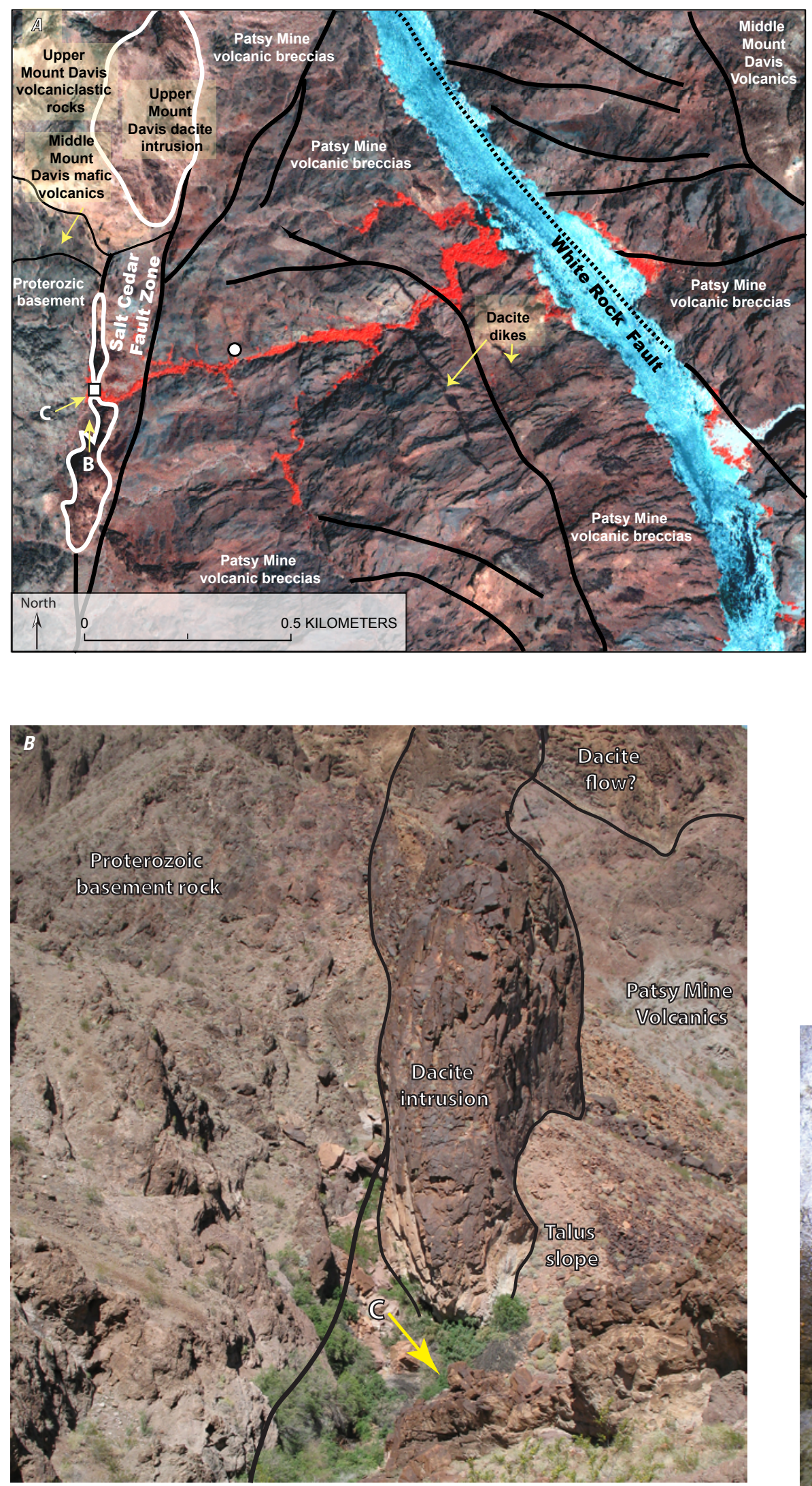

Figure 10. A, Quickbird satellite falsecolor image (DigitalGlobe, 2006) showing vegetation (red) in Salt Cedar Canyon. Dot shows location of water chemistry sample site by L. Justet (written commun., 2010). Blue is Colorado River; red vegetation along shoreline is supported by river water. Broad red vegetation zones that extend west from river outline Salt Cedar Canyon and its tributaries. Thermal waters flow down canyon from area marked "C" and tributaries as well as locally seeping from canyon walls. East-northeast trending fabric is ledges of Patsy Mine volcanic breccias that strike easterly and dip south. Dark irregular north northwest-striking lines in central part of image are dacitic dikes. Heavy black lines show faults, thin black lines are contacts. White line outlines dacite intrusion along Salt Cedar Fault, shown in $B$. $B$, Photograph showing view to north along Salt Cedar Fault at the head of Salt Cedar Canyon. Large dark mass is dacite intruded along fault. Thermal waters, marked by green vegetation, discharge from fault and margins of dacite intrusion. Arrow labeled " $\mathrm{B}$ " on figure $10 \mathrm{~A}$ shows view path of photograph. Arrow labeled " $C$ " shows location of photograph in 10C. Photograph taken by L.S. Beard, April 17, 2009. C, Photograph showing thermal waters discharging from an orifice at the margin of the dacite intrusion. Whitish material is gypsiferous salt encrustations. Rock hammer is about $35 \mathrm{~cm}$ long. Square labeled " $\mathrm{C}$ " on figure $10 \mathrm{~A}$ marks location. Photograph taken by Z.W. Anderson, April 17, 2009.

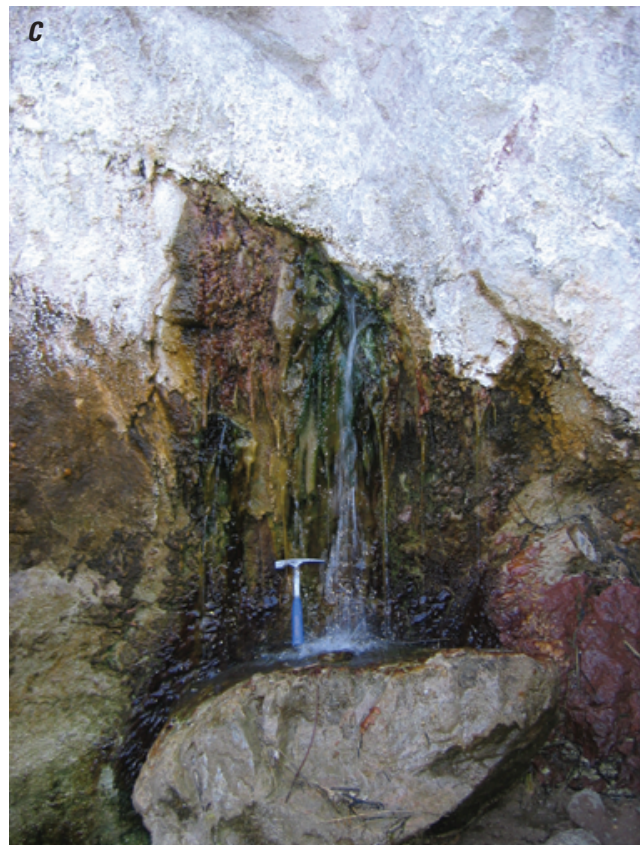




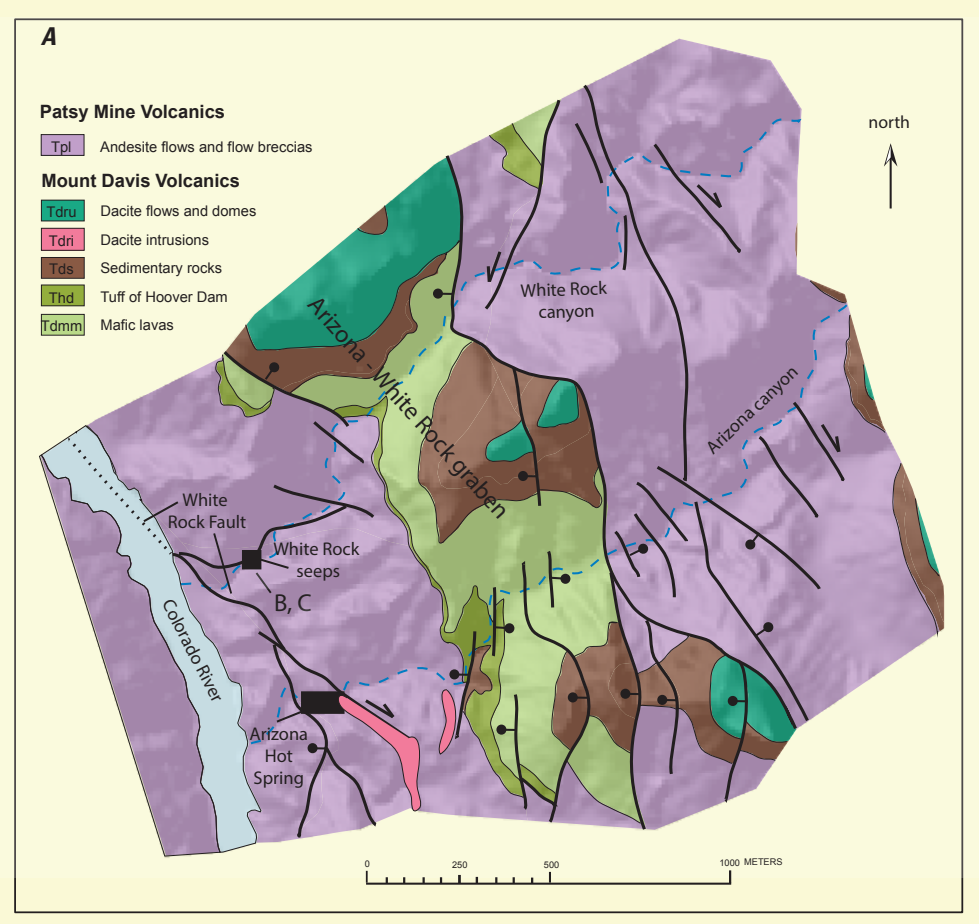

Figure 11. A, Geologic map of the White Rock and Arizona Hot Spring Canyons (AZWR); generalized from 1:48,000-scale geologic map (Felger and others, 2014). Middle and upper Mount Davis volcanic rocks are mostly confined to a northerly-trending graben, with the larger displacement fault on the east side and the west-bounding fault ending southward. Note difference in strike of faults cutting Mount Davis rocks compared to those restricted to Patsy Mine Volcanics. " $B$ " and " $C$ " indicate location of photograph and stereonet plot in figs. $11 B$ and $11 C$. $B$, Photograph showing view to west of north-dipping normal fault in White Rock Canyon that controls the White Rock seeps. Seeps are exposed behind photographer. Heavy yellow line follows trace of main fault; dashed line shows dip of volcanic rocks in hanging wall. Photograph taken by L.S. Beard, April 14, 2009. C, Stereonet plots of faults near the seeps; main controlling fault shown in photograph $11 B$ is marked by star. Lines show direction of striae on fault plane, arrows show known sense of slip. Single arrows are normal faults, double arrow indicates right-slip.

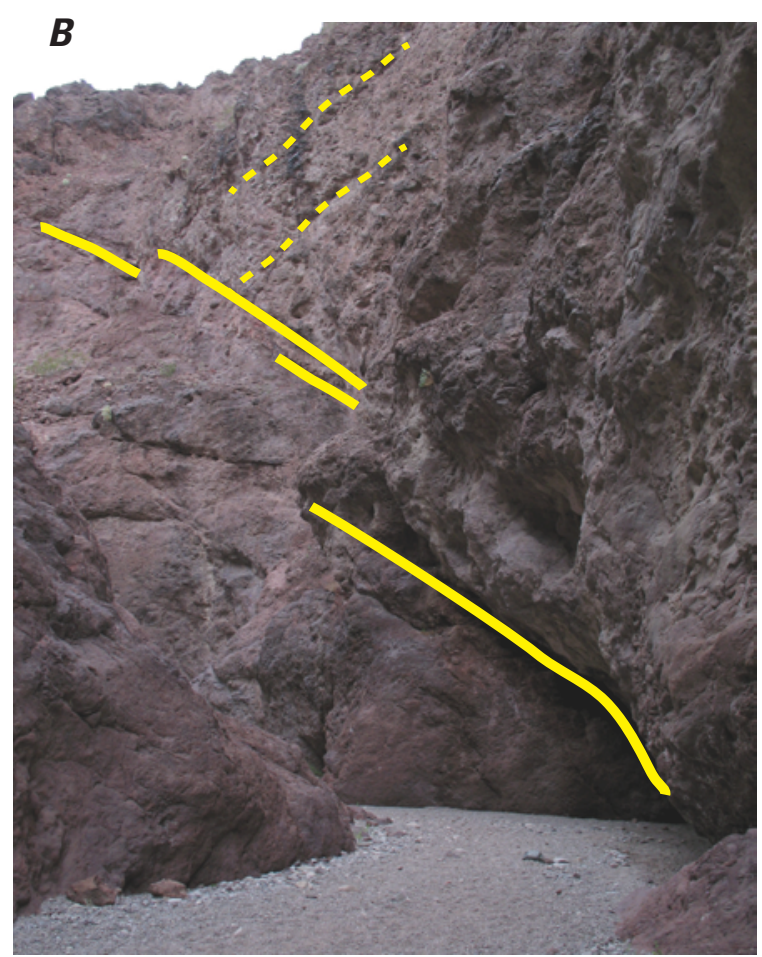

C

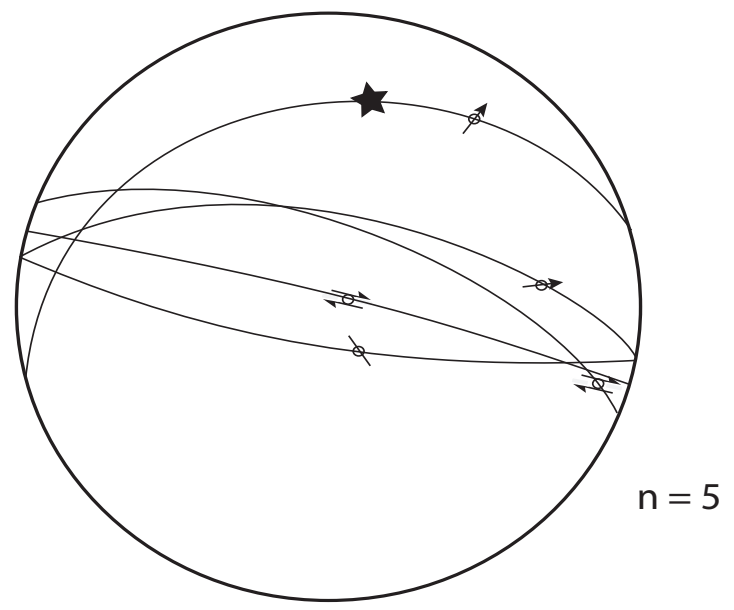

12C). Neither set of striae is distinguishable as dominant nor younger; perhaps movement along the arcuate geometry of the fault formed essentially contemporaneous striae.

At its southwestern end, the Bighorn Fault turns southward or links with one or more west-dipping normal faults (fig. 2). Northward, the Bighorn Fault strikes north-northwest parallel to the river and terminates near Salt Cedar Canyon.

\section{Kinematic Analysis of Fault Data}

Kinematic analysis of fault-slip data yields important insights into the structural geologic history and is useful in evaluating the hydrogeology. We collected 215 data points from faults around the springs of interest. Data collected in the field include fault attitude, rake of striae, and slipsense where determinable. Analysis consisted of generating stereonet plots and rose histograms with the commercial Tectonics FP program (TectonicsFP, 2013) to evaluate the spatial orientation and distribution of faults. For some fault sets, kinematic fault-plane solutions were generated using the techniques of Allmendinger (1989) and Marrett and Allmendinger (1990) to examine kinematic compatibility and the orientation of principal strain axes. Striae data collected as rake were converted to trend and plunge for use in both TectonicsFP and FaultKinWin programs. A contoured stereographic projection plot of the fault data shows multiple maxima, indicating a heterogeneous population that 

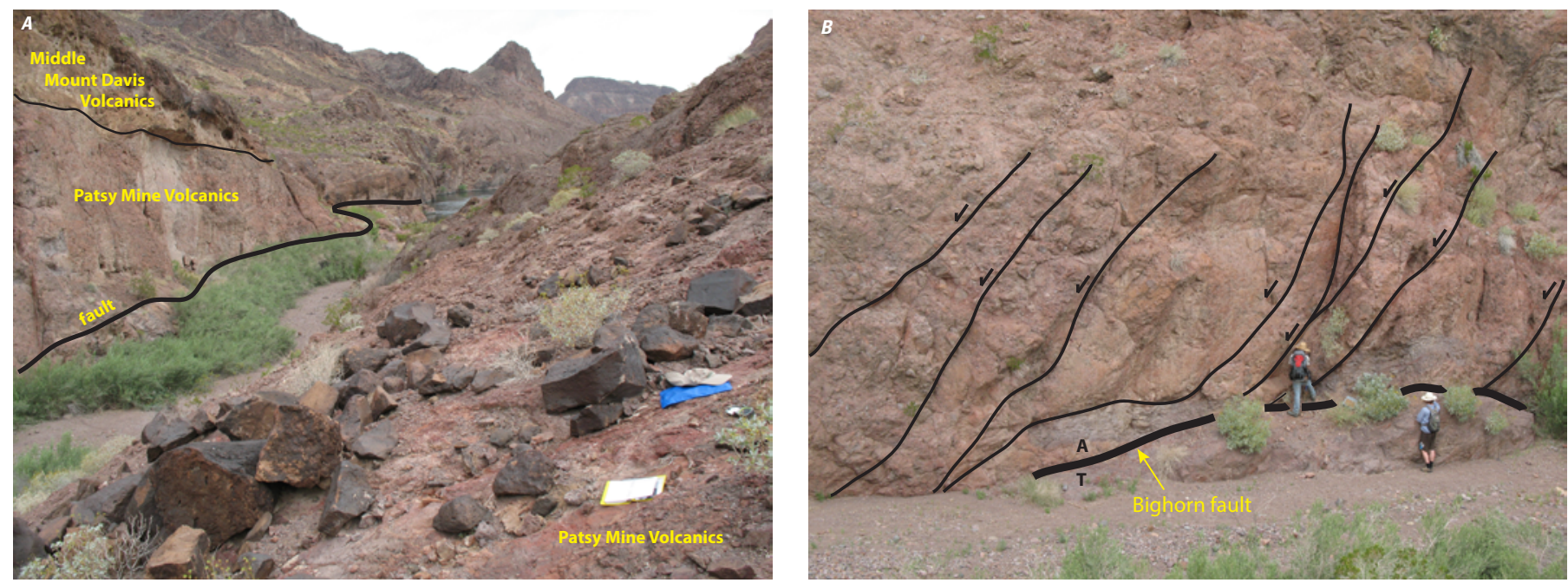

Figure 12. Photographs showing $(A)$ view to northeast along trace of Bighorn fault. North side (left side of canyon) are middle Mount Davis volcanic rocks overlying Patsy Mine volcanic rocks; south (right) are Patsy Mine volcanic rocks. Items in foreground are on fault plane (shown by diagonal lines), which dips shallowly to the north-northwest into the wash. Photograph taken near mouth of Bighorn Canyon. $B$, View of north side of Bighorn Canyon. Numerous west-side-down faults that cut Mount Davis volcanic rocks in hanging wall shallow in dip against Bighorn Fault plane, shown by heavy black line. Rocks directly in front of geologist with white hat are in the footwall. Fault offset shown by: $A=$ away, $T$ = toward. $C$, Cross-cutting striae, indicated by dotted lines, on a fault surface in Bighorn Canyon. All photographs taken by L.S. Beard, April 14, 2009.

represents more than one deformation event (fig. 13). A rose diagram of strikes shows bimodal distribution of both fault strike and striae rake. Faults strike mostly northwest with a lesser population that strikes north to northeast, and striae rake include normal and strike-slip with a minimum at 45 degrees. Based on field relations as described in the previous section ("Geologic Controls on Spring Discharge"), fault data were grouped for analysis. Key field data that guided the analysis include the older and younger normal fault sets mapped in AZWR Canyons; the counterclockwise bending of north- and northwest-striking faults west of Hoover Dam that are cut by younger faults; and the spatial distribution of right- and left-lateral strike-slip faults. In addition, similar to a paleostress fault analysis in the Hoover Dam area by Angelier and others (1985) and a paleostrain fault analysis along the LVVSZ (Duebendorfer and Simpson, 1994), strikeslip and normal faults were analyzed separately. As discussed in Duebendorfer and Simpson (1994), separation of the fault data into various domains based on strike, dip, and slip-sense does not necessarily indicate separate kinematic episodes; some of the sets are almost certainly kinematically linked.

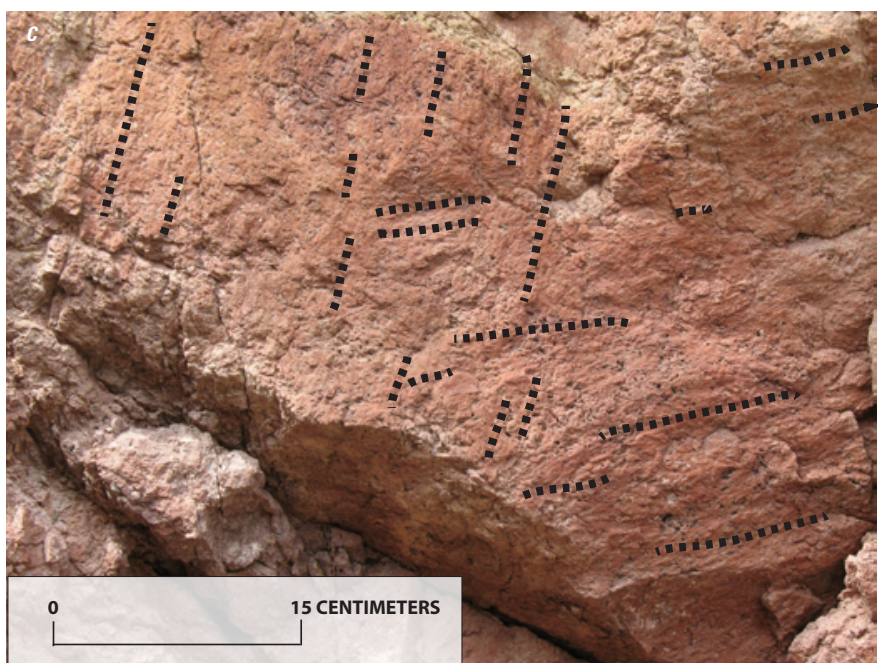

Rather, the separate sets allow objective analysis of kinematic compatibility. Specifically, kinematic compatibility is permissive in datasets that yield a single shortening or extension axis. Details of the analysis are available in appendix 1 and are summarized in this section.

Although fault strike, dip, and rake generally are measurable quantities with low error ranges, determination of the slip-sense is done with considerable uncertainty and the error can be as large as $180^{\circ}$. In this study, slip-sense was not defined for many of the faults. Because it is a required attribute in kinematic analysis, we assigned a slip-sense consistent with regional faulting patterns in the Lake Mead area; that is, northwest-striking right-lateral faults, northeast-striking left-lateral faults, and northerly normal faults (Angelier and others, 1985; Anderson and others, 1994; Duebendorfer and Simpson, 1994; Cakir and others, 1998; Beard and others, 2011a). We refer to the assigned values as "regional default slip" (RDS) and describe the process, assumptions, and a test of RDS in appendix 1.

The kinematic structural analysis, along with geologic mapping (fig. 2; Felger and others, 2014), indicates that the full 


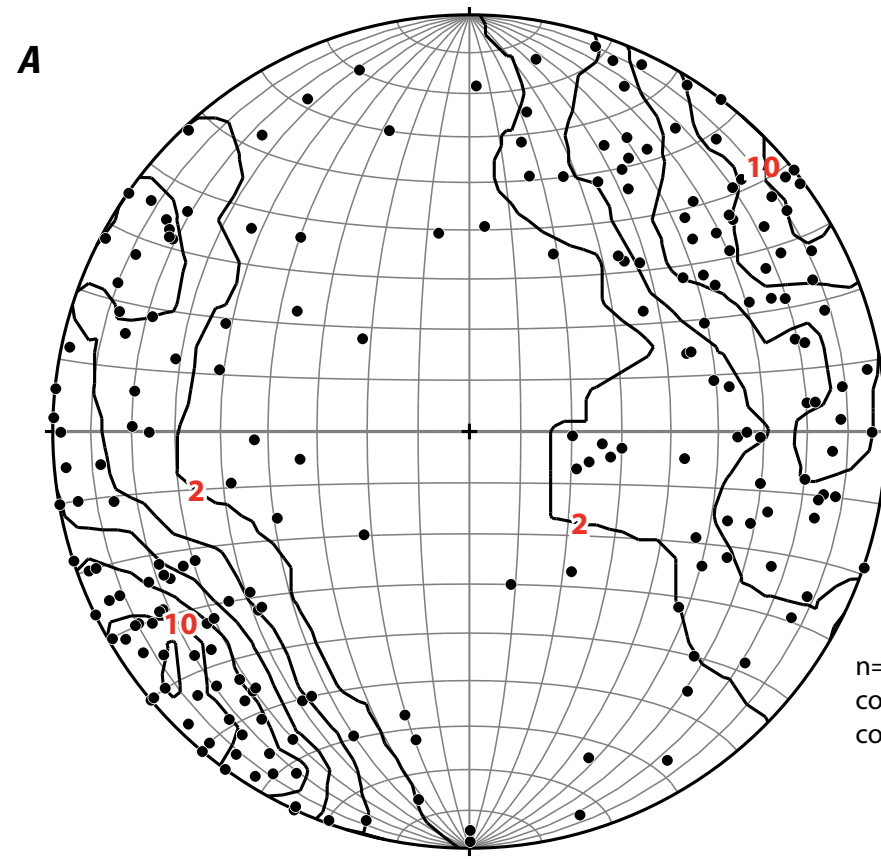

Contour of poles to faults

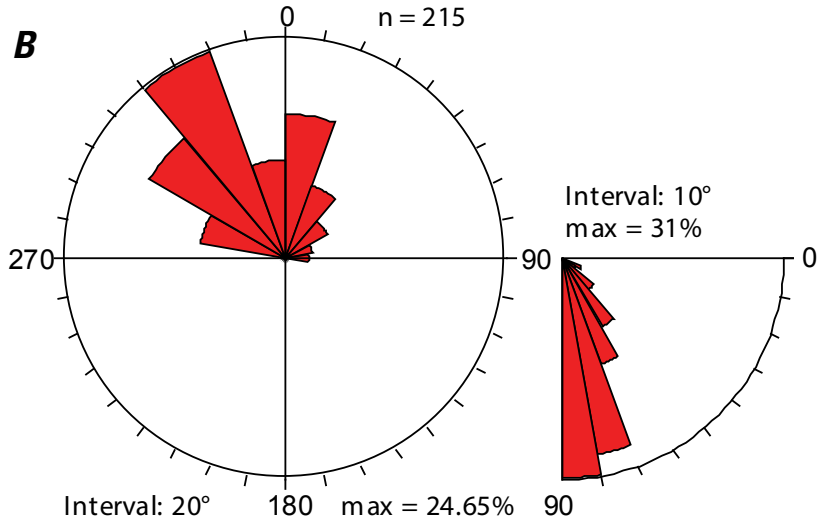

Fault strike

$n=215$

contour interval $=2$ sigma

counting area $=4 \%$ of net

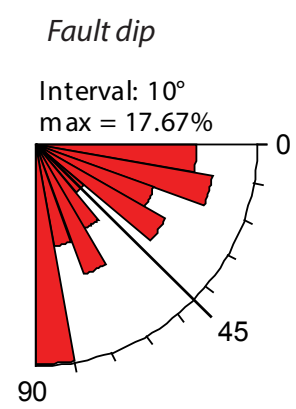

Figure 13. A, Equal-area stereonet of poles to all faults, contoured by Kamb method (contour interval is 2-sigma values, or deviation from uniform distribution). $B$, Rose histograms of fault strike (upper left, circular diagram with red petals), fault dip (upper right, pie diagram), and rake of fault striae (lower right, pie diagram). Maximum percentages are for populations in the longest petals.

population of measured faults in Black Canyon strike dominantly northwest with subordinate northern and northeastern populations. Rake angles have a bimodal steep and shallow distribution (fig. 13). Two sets of moderately to steeply dipping normal faults were identified in AZWR Canyon area, an older north-northwest striking set that predates the upper Mount Davis rocks and a younger north-northeast striking set that cuts the Mount Davis rocks (fig. 14). Normal faults of both sets dip dominantly westward and southwestward near Hoover Dam and westward in Bighorn Sheep Canyon (see map pattern in fig. 2), but form conjugate (graben) systems in the AZWR Canyon area (fig. 14). Both sets formed during Miocene east-west extension, but with an apparent 25-degree clockwise shift in the extension direction with time. A subset of the older normal faults includes moderately west dipping faults that are rotated counterclockwise at least 60 degrees (fig. 15) between Hoover Dam and Hemenway Wash. The rotation may be accommodated by a combination of bending and slip along northwest-striking right-lateral faults (Anderson and Beard, 2011) that cut older normal and strike-slip faults. The rotation is discussed in more detail in the section entitled "Interpretation of Fault Kinematic Data."

Strike-slip faulting was active during the younger and older normal faulting events and recorded an important component of north-south constrictional strain coeval with extension. Field observations at the northern end of the study area indicate some of the strike-slip faults were rotated counterclockwise and cut by younger northwest-striking faults (Seixas and Beard, 2011). The strike-slip faults form four groups (fig. 1A; appendix 1, fig. A8), the first three of which formed during the Miocene extension. Most are in the first two groups: northwest-striking right-lateral faults and northeast-striking left lateral faults. The other two groups are east-west striking faults whose strike results at least partly from rotation and overprinting of the first two groups (fig. 16); and a minor north-striking subset of strike-slip faults that may represent youngest, post-Miocene deformation under northwest-southeast extensional stresses. This set includes Salt Cedar Fault Zone, which is interpreted as a reactivated normal fault.

\section{Interpretation of Fault Kinematic Data}

Field observations and fault kinematic analysis (appendix 1) indicate two Miocene deformation events with distinct extension directions; an older west-southwest-directed event and a younger west-northwest-directed event, with a significant component of north-south constrictional strain beginning during the earlier event and continuing through the later event. The two extensional events are best displayed in White Rock and Arizona Hot Spring Canyons (figs. 11A and 14), where Patsy Mine rocks are cut by faults of both groups, whereas middle and upper Mount Davis rocks within the AZWR graben are cut only by faults of the younger group.

Anderson (1971) noted that faults that cut the youngest volcanic rocks in the southeastern Eldorado Mountains strike 

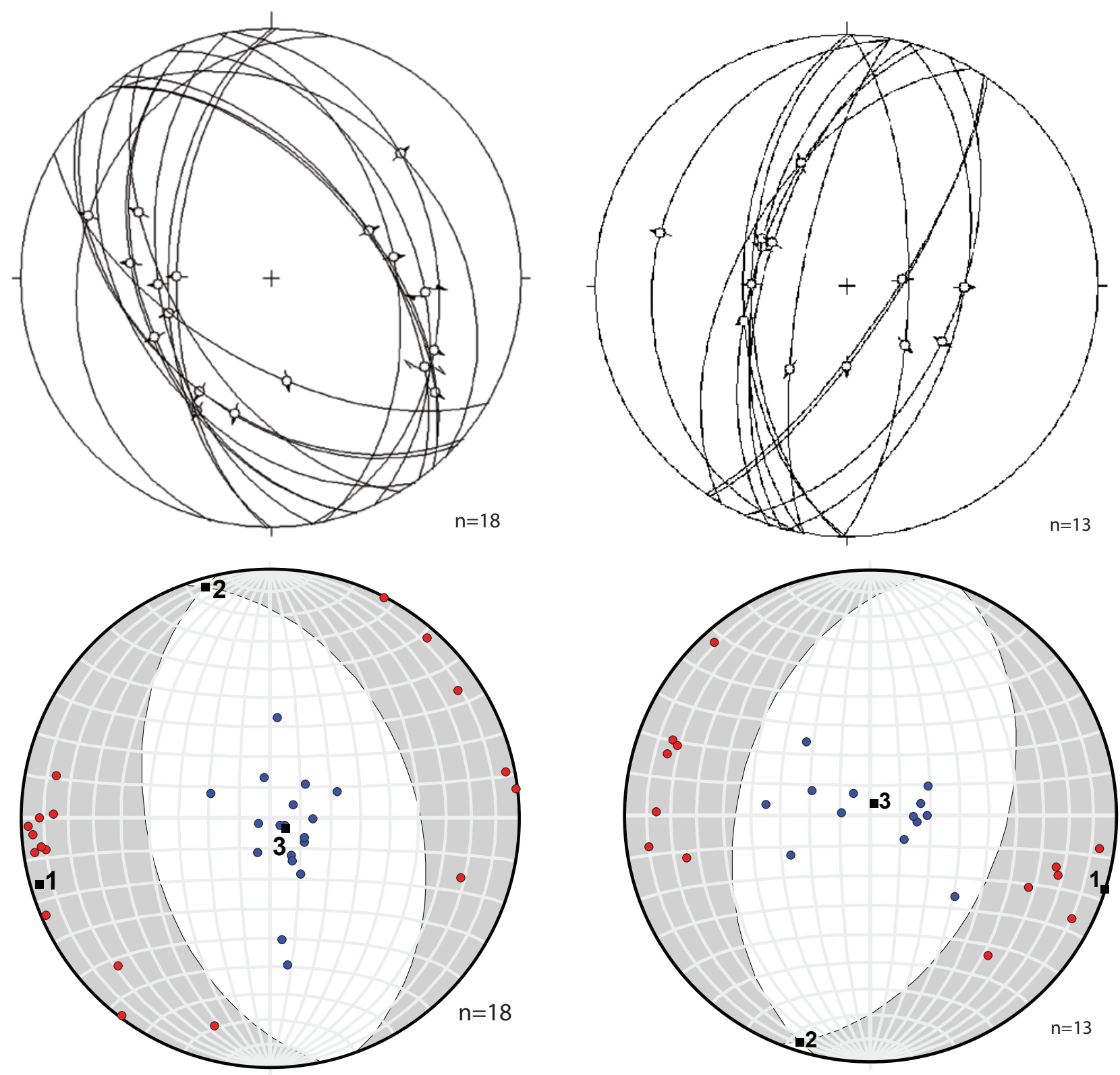

-Fault Plane Solution-

$\begin{array}{llllll}\text { Fault } & \text { Strike } & \text { Dip } & \text { Trend } & \text { Plunge } & \text { Slip Sense } \\ \text { 1. } & 339.4 & 41.2 & 078.0 & 40.9 & \mathrm{~N} \\ \text { 2. } & 168.0 & 49.1 & 249.4 & 48.8 & \mathrm{~N}\end{array}$

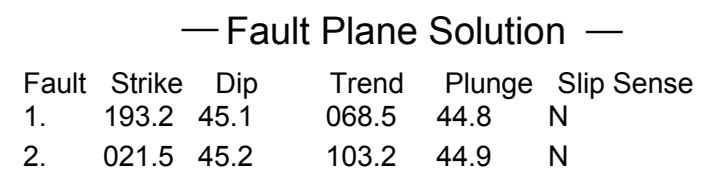

Figure 14. Equal-area steronets and kinematic fault-plane solutions from normal-fault subsets in Arizona Hot Spring-White Rock (AZWR) Canyons showing difference in strikes and extension directions between inferred older and younger fault generations. Kinematic fault-plane solutions shown on right; red and blue dots are $\mathrm{T}$ and $\mathrm{P}$ axes, respectively. Bingham axes are numbered as: $1=$ extension axis, $2=$ intermediate axis, and $3=$ shortening axis. Orientation of fault planes and Bingham axes shown below fault plane solution. $A$, All north-northwest striking normal faults in AZWR Canyons. These faults are dominantly within the Patsy Mine rocks and thus are inferred to represent the older deformation. The extension direction is west-southwest. $B$, All north-northeast striking normal faults from AZWR Canyons, many of which cut the Mount Davis Volcanics and are inferred to represent the younger deformation. The extension direction is east-southeast. 


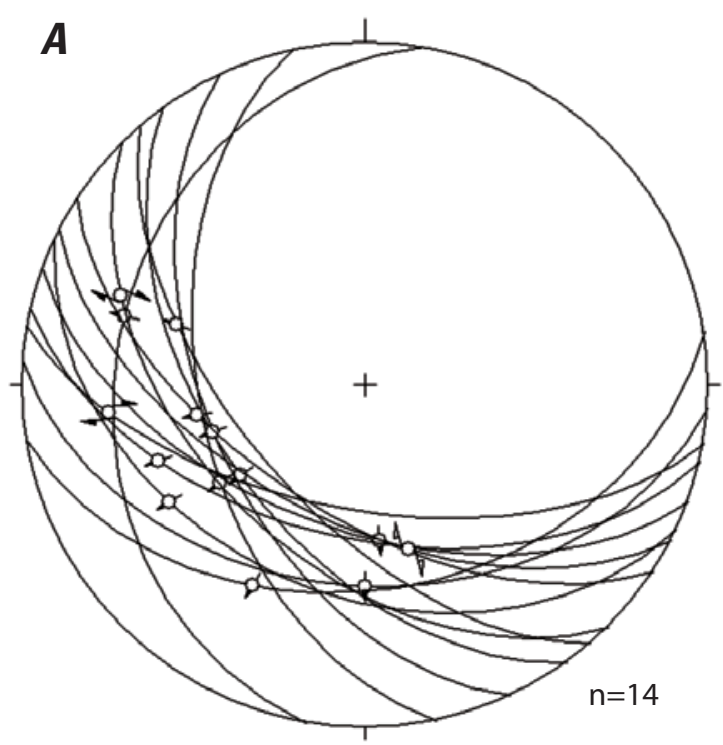

Fault planes

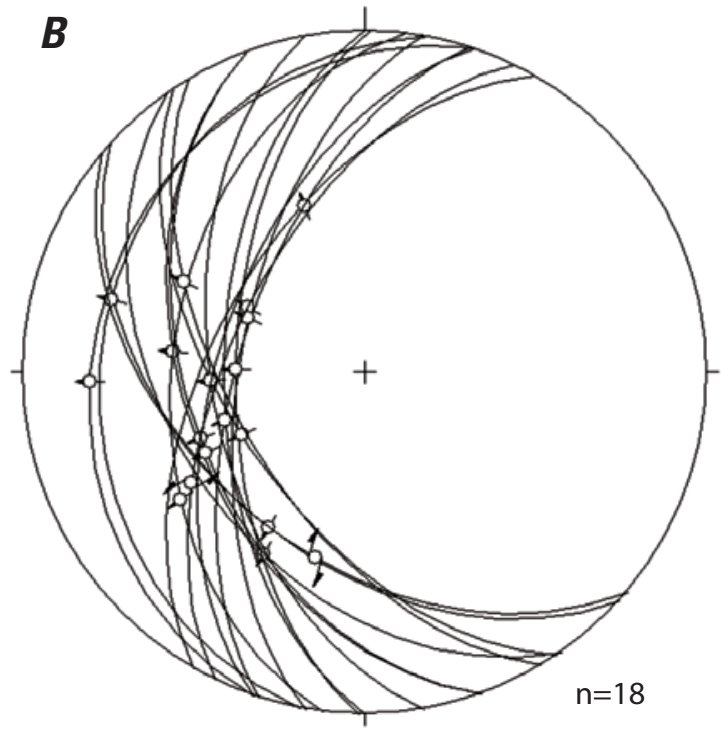

Fault planes

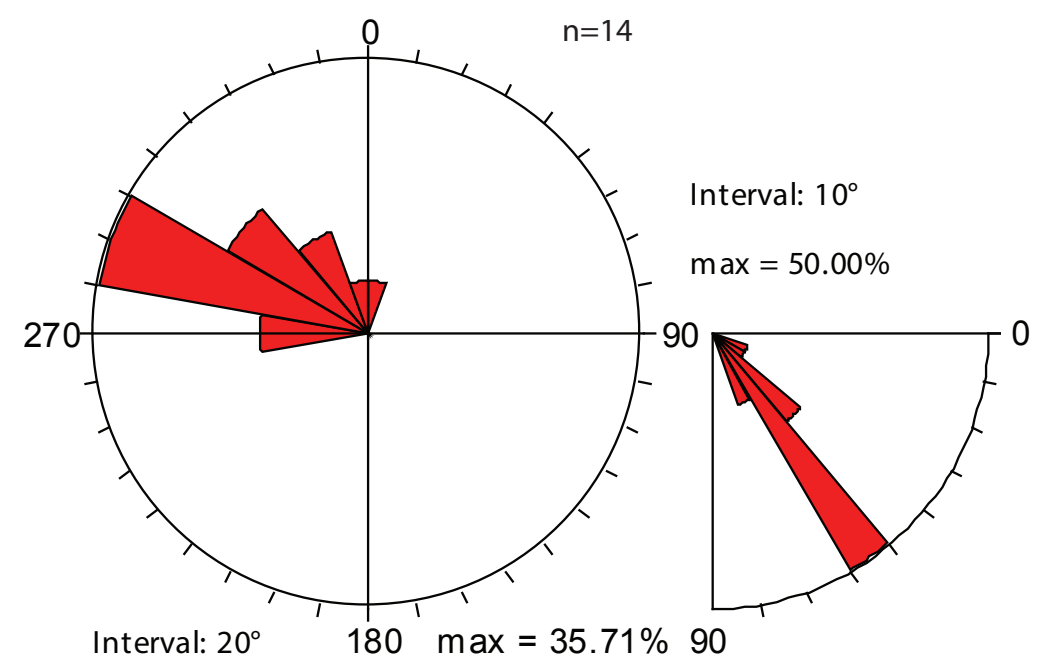

Fault strike

Fault dip

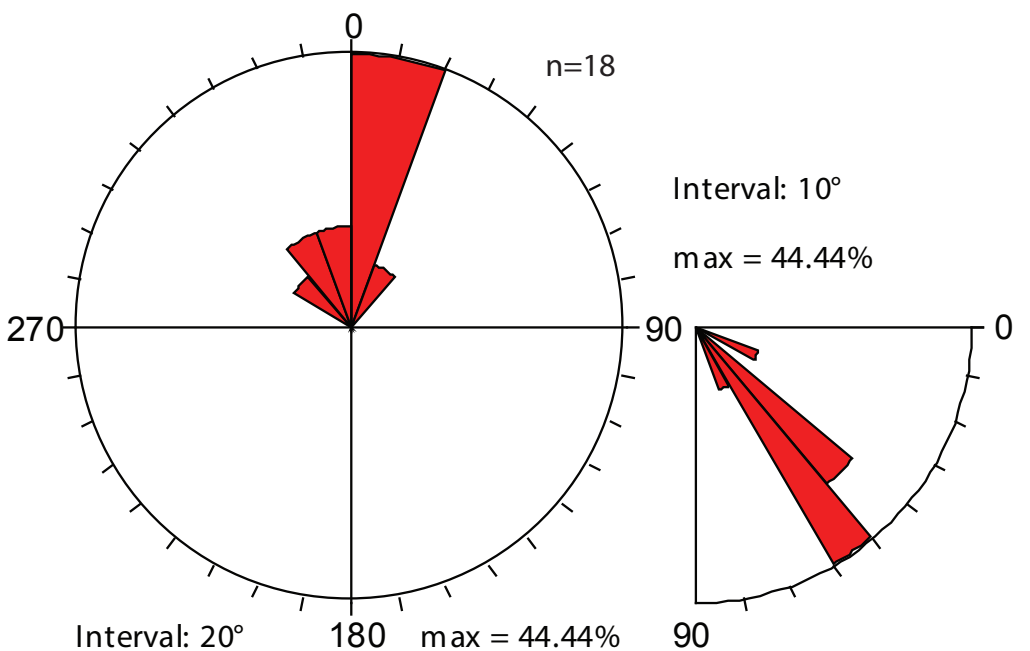

Fault strike

Fault dip

Figure 15. Equal-area stereonets (left) and rose histograms (right) of west- to south-dipping normal faults with dips less than or equal to 60 degrees (Subset 1a). Rose histograms show azimuth of fault-plane strike (circular diagram with red petals) and dip of fault plane (pie diagram with red petals). $A$, West- to south-dipping faults measured from Goldstrike Canyon north to Hemenway Wash. Red fault planes on stereonet are adjacent to Palm Tree fault zone. $B$, Plots of west-dipping faults from White Rock to Bighorn Sheep Canyons. Note almost 60 degrees counterclockwise difference in strike between $A$ and $B$. Red fault planes on stereonet are from Arizona Hot Spring-White Rock graben. See appendix 1 for detailed discussion. 


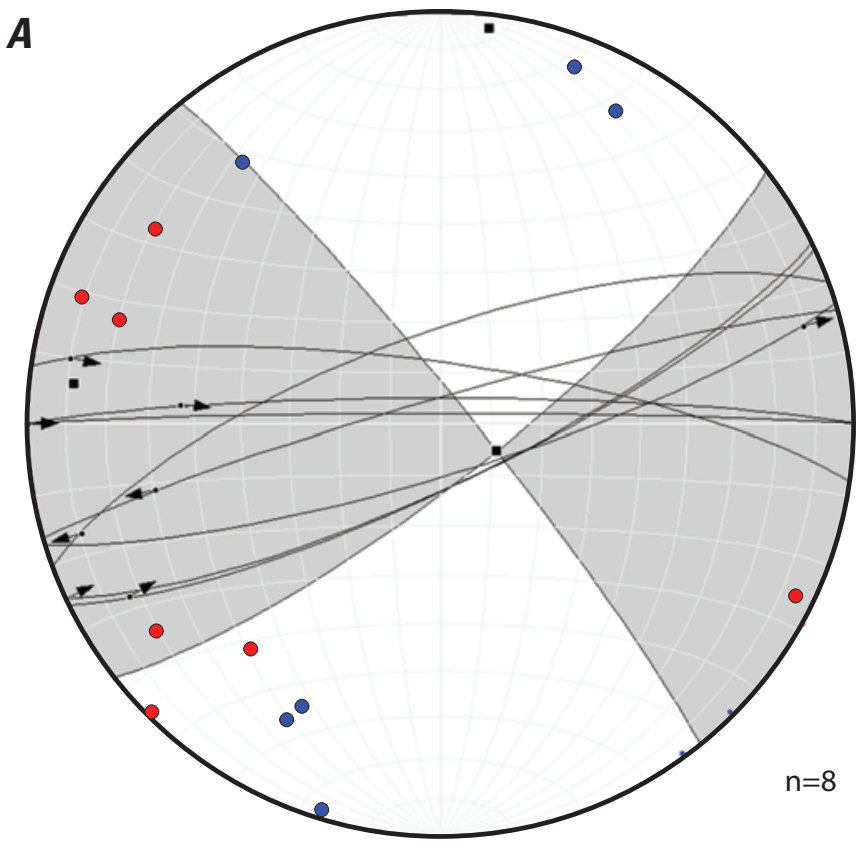

—Fault Plane Solution-

Fault Strike Dip Trend Plunge Slip Sense

$\begin{array}{llllll}1 . & 052.1 & 79.0 & 231.1 & 05.3 & \mathrm{~T}\end{array}$

2. $\quad 321.1 \quad 84.7 \quad 037.9 \quad 11.0 \quad \mathrm{~N}$

P-axis: 007.0, 04.0; T-axis: 276.2, 11.5

—Linked Bingham Analysis-

Axis Eigenvalue Trend Plunge

$\begin{array}{llll}1 . & 0.2247 & 276.2, & 11.5\end{array}$

2. $0.0063 \quad 115.7,77.8$

3. $0.2184007 .0,04.0$

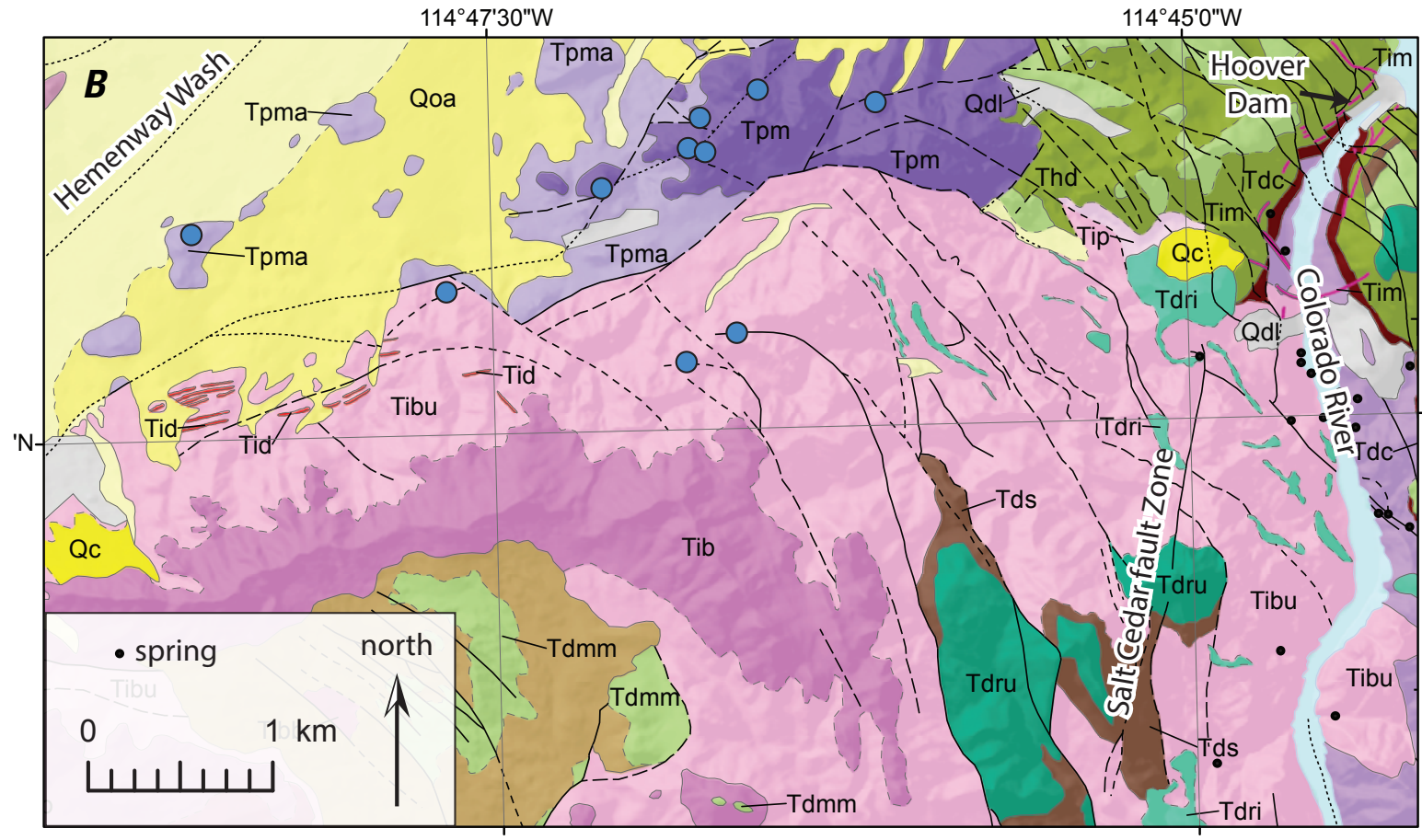

Figure 16. A, Equal-area stereonet plot of east-west strike-slip fault planes measured at northern end of study area, overlain on kinematic fault-plane solution. Red and blue dots are T and P axes, respectively. Arrows indicate direction of strike-slip offset. $B$, Geologic map of northern part of study area west of Hoover Dam. Geologic units same as figure 2. Blue dots show location of east-west strike slip faults in northern part of study area plotted in A. Note sharp bending of some faults. 
northerly and record roughly west-northwest-directed extension, compared to older faults that strike northwest and record west-southwest-directed extension. The change in fault strike corresponds to a regional unconformity between the lower (15.1-14.9 Ma) and middle Mount Davis Volcanics (14.2-13.2 $\mathrm{Ma})$ traceable from the southern Eldorado Mountains northward to Hoover Dam, where it is overlain by the Dam Conglomerate (Tdc).

Similar to the results of our structural analysis, two paleostress studies near Hoover Dam also identified two Miocene deformation events (fig. 17). Angelier and others (1985) reported faults at Hoover Dam that yielded two extension directions differing by about 60 degrees, an older west-southwest and a younger west-northwest direction. A paleostress study by Faugére (1985) of structures within the 14-12 Ma volcanic and sedimentary rocks of the River Mountains defined three extension directions: (1) an older north-northwest direction, (2) an intermediate west-southwest, and (3) a youngest west-northwest direction. The oldest extension direction of Faugére (1985) is restricted to the hanging wall of the Saddle Island Fault and was not identified in our fault analysis although the north-dipping, low-angle fault in White Rock Canyon could possibly be part of that deformation event (fig. 11). His data from the eastern side of the River Mountains yielded consistent intermediate and younger extension directions with angular differences of about 34 degrees, whereas the extension directions from the northwestern River Mountains differed by as much as 66 degrees, and the directions from the southwestern River Mountains by as little as 17 degrees (the latter two are not shown in fig. 17).

Rittase (2004) conducted a fault kinematic study in the western River Mountains (area overlaps with southwestern site of Faugére [1985]) and concluded there were two episodes of extension, an older 13.5-9 Ma stage, and a late Pliocene(?) to Present stage. Within the older extension phase, he suggested the deformation was best explained by orthorhombic faulting in response to two corrugations in the underlying Saddle Island Fault. His older corrugation, oriented northeastsouthwest, would correspond to the earlier west-southwest extension documented in this and earlier reports, and the younger corrugation, oriented northwest, would correspond to the later west-northwest extension direction.

The paleostress study at Hoover Dam by Angelier and others (1985) indicates that faulting occurred both pre- and post-tilting of volcanic rocks. They measured about 500 strike-slip and normal faults, mostly in the Tuff of Hoover Dam and fewer measured in overlying Mount Davis rocks. Their results indicate two stages of combined normal and strike-slip faulting, the older being pre to syn tilting, and the younger post-tilting. They recognized a 60 degrees divergence in extension direction between the older and younger events that may have resulted from a clockwise rotation in the stress field, a counterclockwise rotation of the rocks about a vertical axis, or a combination of both.

A paleomagnetic study by Geissman and others (1989), measured mostly in the Tuff of Hoover Dam but also older and younger rocks, documents about 35 degrees of relative counterclockwise rotation of rocks over a distance of $3 \mathrm{~km}$ near the Hemenway Wash and Mead Slope strands of the LMFS (fig. 2). Counterclockwise rotations were determined relative to rocks southeast of the Hoover Dam and increase towards Hoover Dam and the LMFS (fig. 18). Geissman and others (1989) noted bedding attitudes also rotate counterclockwise from south to north and mimic the changes in declination of the paleomagnetic data.

Similarly, the strikes of faults and of volcanic contacts in the study area also indicate counterclockwise rotation as they approach the LMFS, as documented in this report (figs. $15 B$, $15 C$, and 16). The rotation is most pronounced at the northern end of the Boulder City pluton, perhaps because of a buttressing effect of the pluton on the southern side of the left-slip LMFS and the north-south constrictional strain.

Using the results of Geissman and others (1989), Ron and others (1993) concluded the 60 degrees divergence documented by Angelier and others (1985) could be explained by approximately 30 degrees counterclockwise block rotation and 30 degrees clockwise rotation in the stress field. Data collected away from the LMFS from this study and from the eastern side of the River Mountains (Faugére, 1985) also indicate that the rotation of the stress field is no more than 30-40 degrees. Therefore, the older extension direction at Hoover Dam (fig. 17; Angelier and others, 1985) reflects counterclockwise block rotation of at least 30 degrees into the LMFS and about 30 degrees change in the extension direction.

Counterclockwise rotation at the northern end of the study area most likely resulted from a combination of counterclockwise bending and shear along secondary structures related to left-lateral motion along multiple strands of the LMFS (including the Mead Slope Fault and the Hemenway Wash Fault) and south-directed constrictional strain (Anderson and others, 1994, Anderson and others, 2011). Counterclockwise rotation is matched on the northern side of the LMFS in the southern River Mountains, as shown by counterclockwise bending of faults and volcanic and plutonic rocks against the fault zone (Faugere, 1985; R.E. Anderson, U.S. Geological Survey, oral commun., 2010).

Anderson and others (1994) and Gans and Bohrson (1998) report average extension directions (fig. 17), but did not identify multiple deformation events. The paleostress study by Faugére (1985) defined a single deformation event in the Eldorado Mountains with the same extension direction as Gans and Bohrson (1998), and indicated it was overprinted by the younger deformation event near Hoover Dam. Based on map patterns of dikes at the northern end of the Wilson Ridge pluton, Anderson and others (1994) documented a strong bending strain about a sub-vertical axis between the LMFS and the location of the extension direction plotted in figure 17. The strikes of the dikes, from south to north toward the LMFS, first rotate clockwise then bend sharply counterclockwise against the Hamblin Bay fault segment of the LMFS. Anderson and others (1994) do not attribute these vertical-axis rotations to drag or secondary faulting related to the LMFS, rather 


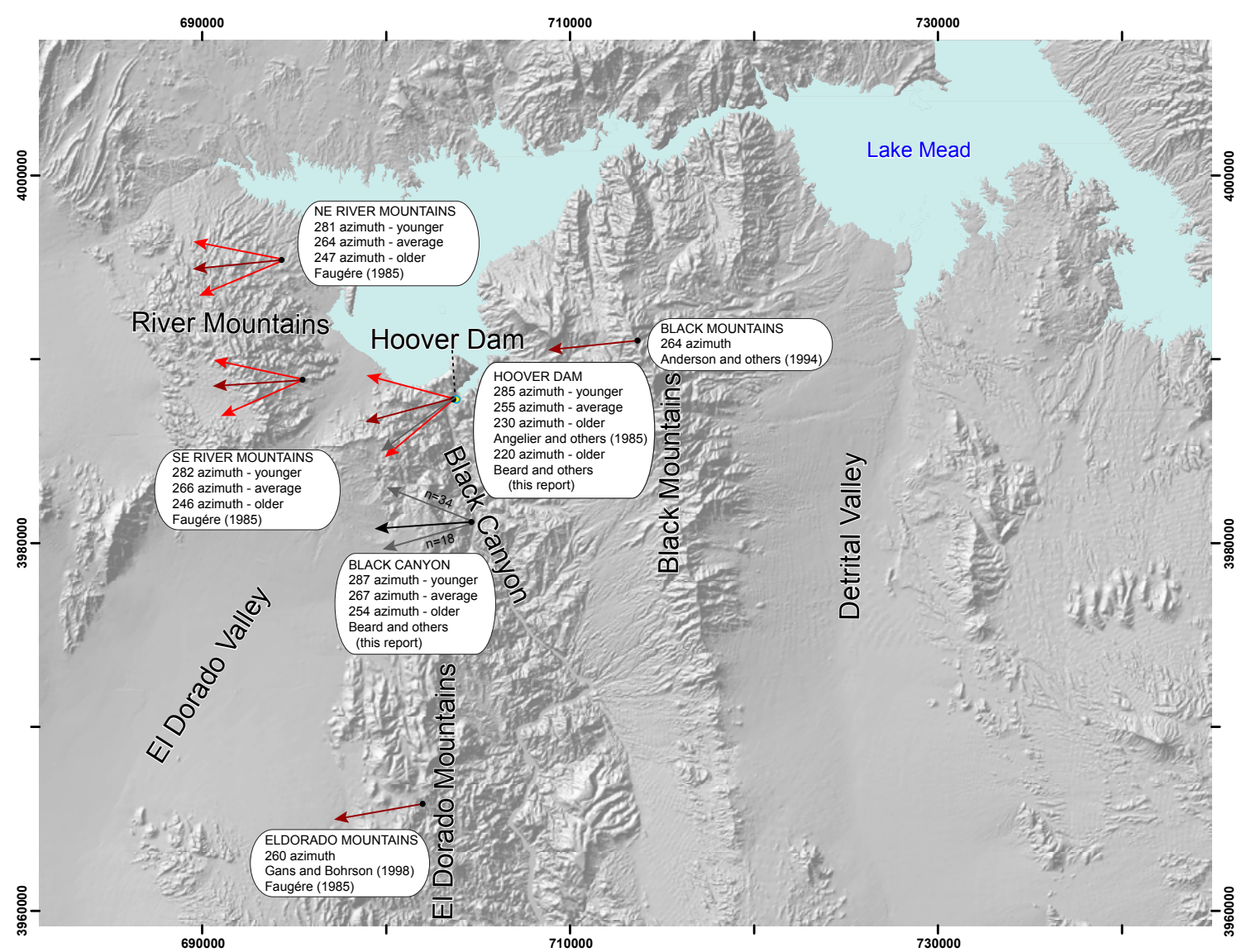

Figure 17. Summary of some published extension directions for the southwestern Lake Mead area. Base is 10-meter digital elevation model. Black arrow represents average extension directions from kinematic strain analysis. Grey arrows represent extension directions for older and younger fault sets from different studies. Dark red arrows represent average least compressive stress directions from paleostress studies. Light red arrows represent least compressive stress directions for older and younger fault sets. Data for this study of younger and older extension directions is calculated from the older and younger normal faults in Arizona Hot Spring-White Rock graben (fig. 14), and the average extension direction is calculated from all normal faults (See appendix).

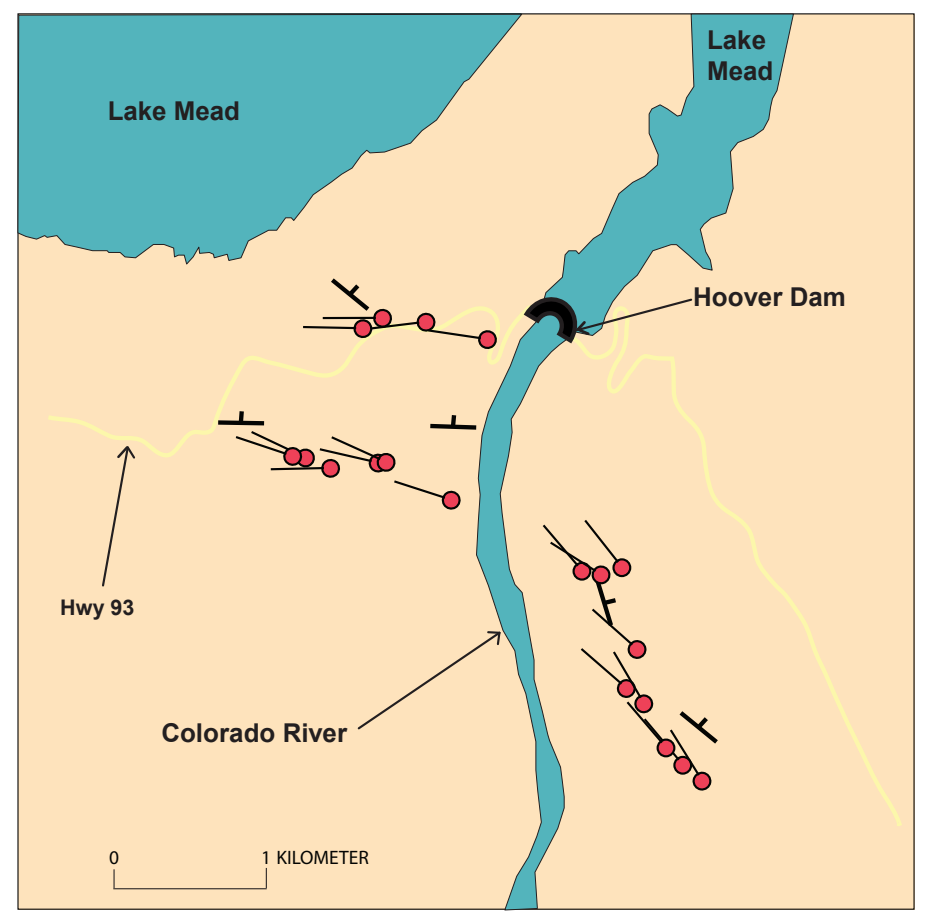

Figure 18. Schematic map showing in-situ declination of paleomagnetic data from 19 sites in the tuff of Hoover Dam and other Mount Davis volcanic rocks (Geissman and others, 1989).

Strike and dip symbols indicate general attitude of bedding. Site mean declinations are plotted as lines from the individual site locations. Note the progressive counterclockwise rotation from south to north. Figure modified from Geissman and others (1989). 
they suggest a vertical or southerly collapse associated with space problems related to late-phase pluton emplacement.

The similar azimuth of extension directions for the younger deformation event, regardless of proximity to the LMFS, indicates that it mostly post-dates counterclockwise block rotation and may be Pliocene or younger in Black Canyon, similar to the conclusion of Rittase (2004) for the northern River Mountains.

\section{Principal Hydrogeologic Structural Features in Black Canyon}

Geologic mapping and structural studies indicate three principal hydrogeologic structural features are in the Black Canyon area, the northwest-striking right-lateral Palm Tree Fault Zone (figs. 6 and 19), the north-striking Salt Cedar Fault Zone, and the north-striking White Rock Fault. The faults may provide deep vertical conduits for movement of groundwater, supported by warm water temperatures $\left(45-55^{\circ} \mathrm{C}\right)$ measured at springs and seeps along these major faults in Black Canyon. The Palm Tree Fault Zone is widely intruded by low-permeability dacite dikes and extends along Palm Tree Canyon northwestward across the river and approximately $1 \mathrm{~km}$ up Goldstrike Canyon, where it terminates in the vicinity of Nevada Hot Spring. This fault zone controls the location of the Palm Tree and Nevada Hot Springs and marks an important change in the chemical and isotopic compositions of groundwater discharge to the north and south of the fault zone (fig. 19). North of Palm Tree Fault Zone, water chemistry of the thermal springs indicates a Lake Mead component to the groundwater, whereas south of the fault the Lake Mead component is not detectible (Justet and Beard, 2010; Justet and others, 2011). The Palm Tree Fault is not apparent eastward into exposures of upper Mount Davis volcanic rocks and may predate them.

The second principal hydrogeologic feature is the north-striking Salt Cedar Fault Zone (figs. 2 and 19), which offsets the Palm Tree Fault Zone right-laterally in Goldstrike Canyon (fig. 19). The fault can be traced only 100-200 m north of its intersection with the Palm Tree Fault to a large dacite intrusion that is the inferred source of the Sugarloaf dacite (Mills, 1994) and that may have intruded into the fault termination. Southward, the fault zone extends as a series of en echelon normal fault segments to south of Salt Cedar Canyon (figs. 2 and 19). The fault zone is coincident with a 5-km-long, westward-increasing gravity gradient (Langenheim and others, 2010), consistent with west side down fault displacement, that extends south to Bighorn Fault (fig. 20).

The White Rock Fault is the third principal hydrogeologic feature that may be the main structure controlling the location of discharge of Arizona Hot Spring. North of the spring, the fault is mapped to the southern end of the Boulder City pluton (fig. 20). Southward, it splays into two faults. The western splay joins a west side down fault that cuts the large Proterozoic basement exposure to the south and is also coincident with a westward increasing gravity gradient. In the subsurface, the fault probably intersects the Salt Cedar Fault Zone to the west because it dips shallower $\left(\sim 45-50^{\circ}\right)$ than the Salt Cedar Fault Zone (plate 1).

Along the Salt Cedar Fault Zone, the highest elevation evidence of surface spring discharge, based on vegetation visible on a Quickbird image dataset (DigitalGlobe, 2006), is at about $300 \mathrm{~m}$ for Nevada Hot Spring in Goldstrike Canyon; the weeping wall adjacent to the dacite intrusion in upper Boy Scout Canyon; the highest vegetation for the Boy Scout "cold" spring (a thermal spring that feeds surface flow down a waterfall in Boy Scout Canyon where it cools to ambient temperature at the base of the waterfall); and the highest elevation spring in Salt Cedar Canyon at the daciteProterozoic basement contact (fig. 2). The consistent elevation of these springs indicates that there is either (1) very high lateral hydraulic conductivity along the Salt Cedar Fault Zone between these discharge sites, or (2) the lateral hydraulic head gradient is perpendicular to the strike of the fault. Steep structural heterogeneities are likely one of the main influences of the location of the springs, such as the fault intersection at Nevada Hot Spring, and the dacite intrusions in the Salt Cedar Fault Zone at Boy Scout and Salt Cedar Canyons. These structural features likely provide conduits for groundwater flow along the faults and may locally inhibit flow across segments of the fault system (Dinwiddie and others, 2012).

The Salt Cedar Fault Zone exhibits normal fault separation, but evidence for right lateral slip in Goldstrike Canyon suggests reactivation and possibly modern offset. An earthquake that occurred in the vicinity in the 1970s (Rogers and Lee, 1976; Anderson and O'Connell, 1993) has a fault plane solution that is consistent with right-lateral slip on the 10 degrees east of north striking Salt Cedar Fault (fig. 19). The approximate depth of the earthquake was $3.5 \mathrm{~km}$, it had a magnitude around 2 , and the focal plane strikes about 8 degrees east of north and vertical. The earthquake was attributed to the Jeep Pass Fault of Longwell (1963; R6, fig. 10, in Rogers and Lee, 1976), which likely correlates to the northern segment of the Salt Cedar Fault. The fault plane solution indicates a northwest-southeast direction of leastcompressive stress across the Salt Cedar Fault that is consistent with open pathways for groundwater movement and discharge along the fault, and likely conducive to a hydraulic connection to Lake Mead water as suggested by Anderson and Laney (1975).

Field observations suggest that the layered volcanic breccias of the Patsy Mine Volcanics, and to a lesser extent, the highly fractured part of the Boulder City pluton likely are local aquifers. Although the permeability characteristics of the volcanic flow breccias are not known, the fracturing and lateral and vertical heterogeneity may provide groundwater flow paths along major faults and possibly in fractures away from the faults, which then allow discharge as seeps and springs. One of the best examples is in Salt Cedar Canyon 


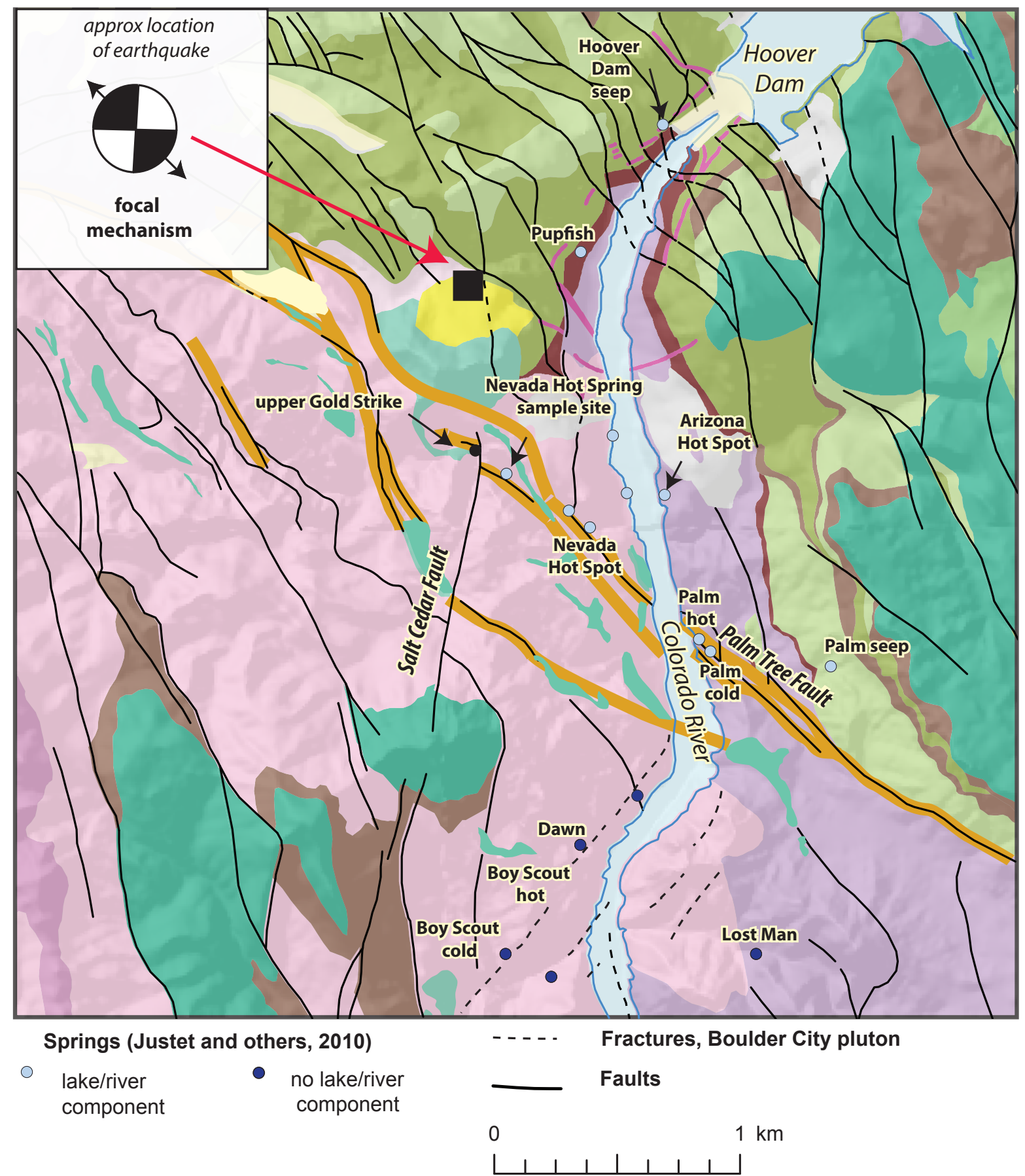

Figure 19. Geologic map showing thermal springs in northern Black Canyon area and presence or absence of Lake Mead component of groundwater shown in relation to major faults. Palm Tree Fault Zone and area of stepover is outlined in orange overprint. Approximate location of earthquake epicenter from Rogers and Lee (1976) is shown by black box and discussed in the section entitled "Principal Hydrogeologic Structural Features in Black Canyon." Geology clipped from Felger and others (2014) and draped on 30-meter digital elevation model. 


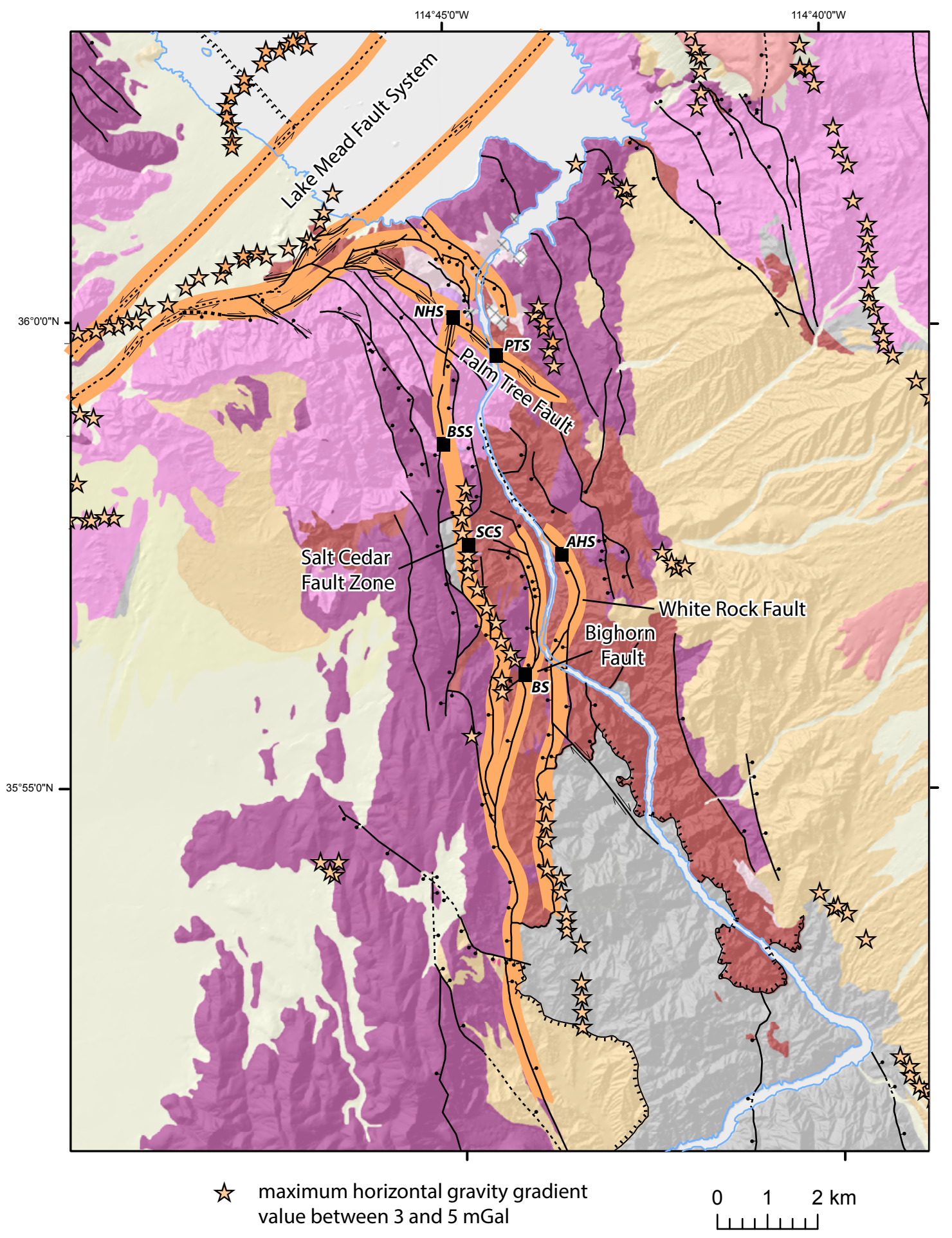

Figure 20. Map showing locations of maximum horizontal gravity gradient steps (stars) from Langenheim and others (2010), overlain on major faults (wide orange lines). Thermal springs on major faults shown by black squares. Base is from regional geologic map (plate 1). See the section entitled "Principal Hydrogeologic Structural Features in Black Canyon" for further discussion. 
where groundwater likely moves from the highest altitude springs at Salt Cedar Fault through the stratified Patsy Mine volcanic sequence and emerges as seeps at contacts within the Patsy Mine volcanic breccias (fig. 10a). The Boulder City pluton may allow transmittal of groundwater away from main fault conduits where it is highly faulted, such as in Goldstrike Canyon, or where it contains the strong preferred fracture orientation in Boy Scout Canyon (fig. 9).

\section{Regional Geologic Cross Sections}

Four regional-scale cross sections were constructed across the western Lake Mead area to visualize geologic constraints on potential regional groundwater-flow paths to Black Canyon (fig. 21, pl. 1). The sections intersect the principal regional geologic structures and other features of likely hydrogeologic significance adjoining Black Canyon. These geologic sections refine schematic hydrogeologic cross sections by McKay and Zimmerman (1983). The geologic base used for the cross sections is the 1:250,000-scale regional geologic map by Felger and Beard (2010), part of which is shown on plate 1; the sections are scaled to 1:100,000-scale. Published cross sections (fig. 21; Anderson, 1977, 1978; Bell and Smith, 1980; Bohannon, 1983; Mills, 1994; Ekren and Anderson, 1996; Castor and others, 2000; Duebendorfer, 2003; Page and others, 2005) were displayed in three dimensions using ESRI ArcScene ${ }^{\circledR}$ software (Environmental Science Research Institute, 2009) to guide the construction. Apparent dips of structural attitudes from these publications, as well as Beard and others (2007) and Felger and Beard (2010), were projected onto the cross-section lines. In addition, profiles along the sections were generated from a geophysical depth-to-bedrock model from Langenheim and others (2010) to constrain the thickness of basin-fill deposits. Sections A-A' and B-B' are oriented northwest and cross the LMFS and LVVSZ, with the northwestern end of section A starting in the upper plate of the Muddy Mountain thrust and section B-B' starting in cratonal Paleozoic and Mesozoic rocks at Frenchman Mountain (fig. 21, pl. 1). Sections C-C' and D-D' extend east and northeast from the McCullough Range through Black Canyon. Both sections cross Eldorado Valley with section C-C' ending on the eastern side of the Black Mountains and section D-D' ending on the eastern side of Detrital Valley (fig. 21, pl. 1).

The remainder of this section of the report describes geologic constraints for each cross section and the key assumptions used in their construction. Only the most extensive outcrops of Quaternary deposits are shown on the cross sections (more than approximately $200 \mathrm{~m}$ thick and $500 \mathrm{~m}$ wide). The geology portrayed beneath large expanses of surficial deposits or Lake Mead is poorly constrained because of a lack of subsurface information and is shown on the sections by dashed lines. The rock units listed in the discussion below are keyed to plate 1 .

\section{Section A-A'}

Major regional structures in section A-A' (from northwest to southeast) include the Muddy Mountain thrust, the LVVSZ, the Frenchman-River Fault, the Saddle Island Fault, and the LMFS (pl. 1). In addition, the section crosses an east-west structural ridge of reverse-faulted Tertiary sedimentary rocks north of Saddle Island (Duebendorfer, 2003; Anderson and Beard, 2010). South of the LMFS, the section crosses the right-lateral Palm Tree Fault and parallels north-striking, west-dipping faults that bound the western side of the Proterozoic crystalline basement exposures west of Willow Beach.

- We interpret the Muddy Mountains thrust to ramp up southeastward and therefore, upper plate rocks are absent southeast of the trace of the thrust. The geology is constrained by the presence of the thrust at the northern end of the section, shown in cross section H-H' of Page and others (2005).

- Two strands of the LVVSZ are shown, a northern strand that ends eastward about where it meets section A-A', and a southern strand north of Frenchman Mountain that we project eastward in the subsurface across the section. The strands are interpreted as part of a step over in the fault system forming a small pull-apart basin on the northern side of Frenchman Mountain (fig. 1; Langenheim and others, 2001).

- We project the Boulevard and Dry Wash Faults that cut unit Tsmo on the edge of Frenchman Mountain eastward into the section (pl. 1). These faults and others between the LVVSZ and the structural ridge are dominantly reverse or transpressional, based on mapping and numerical modeling by Cakir and others (1998) to the northeast, data presented in Anderson and Beard (2010), and kinematic analysis by Wagner (2010) at Frenchman Mountain.

- The strike of the Saddle Island Fault changes from north to northeast on the northern side of Saddle Island. The section crosses the northeast-striking part of the fault, which dips shallowly to moderately northward, based on Duebendorfer and others (1990) and Anderson and Beard (2010).

- Longwell (1936) mapped as much as $1.5 \mathrm{~km}$ of northeast dipping volcanic rocks in the upper plate of the Saddle Island Fault northeast of Saddle Island. This suggests a volcanic section of unknown age (but most likely Tvy), which rests on either Proterozoic or Tertiary intrusive crystalline rock and thins northward or intertongues with the intermediate sedimentary units (Tsmy and Tsmo). Similar relations are mapped to the west in the River Mountains and shown in cross section B-B' (see "Section B-B"'). The volcanic rocks 


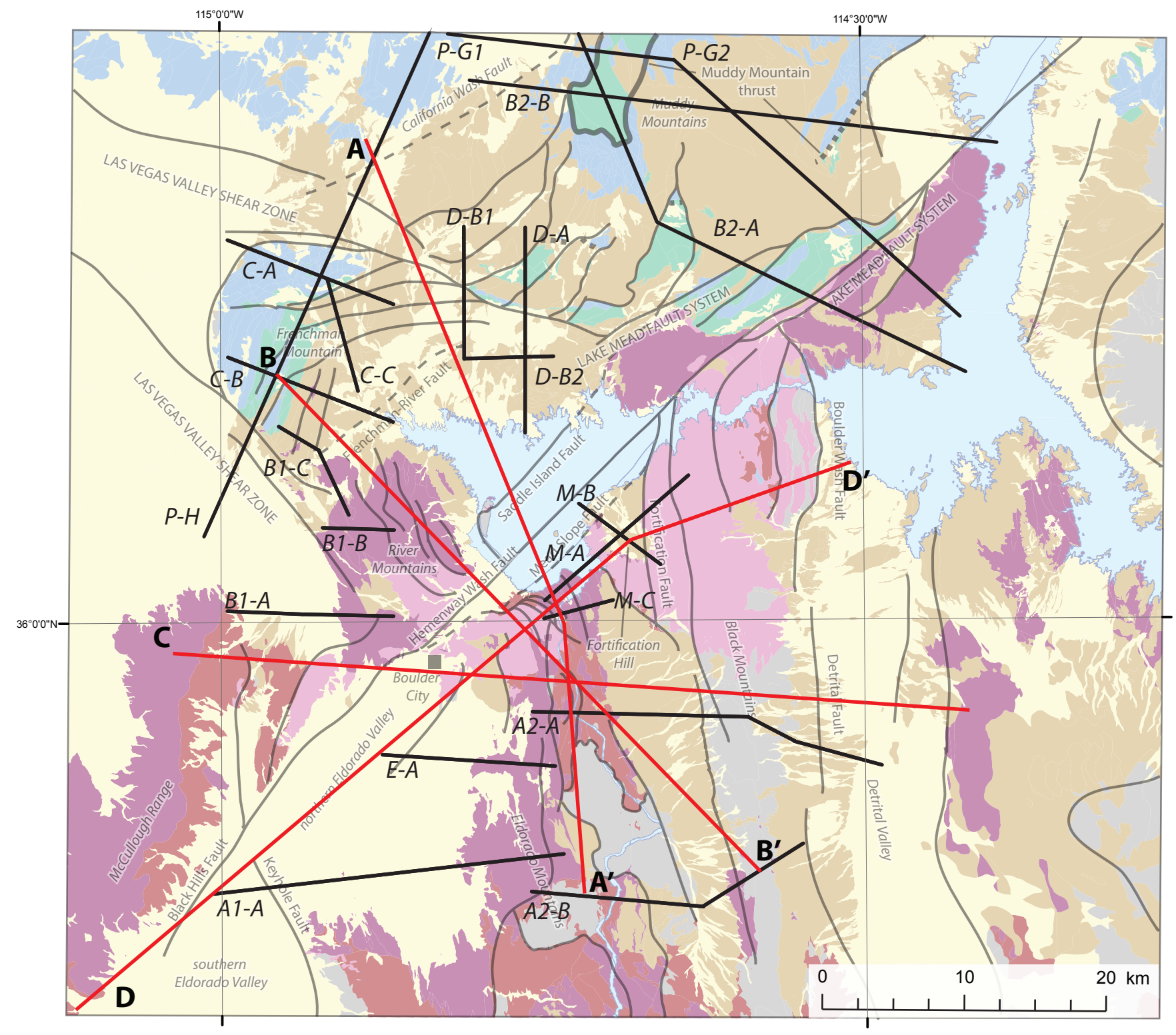

Figure 21. Generalized geologic map showing locations of cross sections (red lines shown in plate 1 of this report). Black lines are published cross sections; italic labels indicate source, followed by section label: A1, Anderson (1977); A2, Anderson (1978); B1, Bell and Smith (1980); B2, Bohannon (1983); C, Castor and others (2000); D, Duebendorfer (2003); E, Ekren and Anderson (1996); M, Mills (1994); P, Page and others (2005). Hydrogeology, faults, and fault names same as figure 1.

are mostly confined to south of the structural ridge (fig. 5 in Anderson and Beard, 2010).

- Most of the Paleozoic and all the Mesozoic section must disappear in the section between the LVVSZ and Saddle Island because only Cambrian rocks are exposed in the upper plate of the Saddle Island Fault (Pz on pl.1 of Felger and others, 2014; Duebendorfer and others, 1990) and rocks as young as Jurassic are exposed west of the section at Frenchman Mountain. This most likely results from a combination of erosion on the north plunge of the Kingman uplift that truncated the strata and a possible northeast-striking left- lateral fault (Frenchman-River Fault of Deubendorfer and others, 1998) between Frenchman Mountain and the River Mountains that juxtaposed different erosional levels of the arch (further discussed in "Section B-B"). These relations indicate that the Frenchman-River Fault predates volcanic rocks of the River Mountains, which intertongue northward with younger intermediate sedimentary rocks (Tsmy) north of the section where they are not cut by the fault. The fault was first described by Bell and Smith (1980) as a zone of discontinuity related to the LMFS. We interpret the fault as left-normal oblique in section B-B', but suggest the fault plane reversed dip eastward, or it was reacti- 
vated along the line of section $\mathrm{A}-\mathrm{A}^{\prime}$ as a left-oblique reverse fault. This reverse component of slip is likely expressed as the structural ridge intersected by section A-A'.

- Based on mapping and numerical modeling by Cakir and others (1998) to the northeast, data presented in Anderson and Beard (2010) and kinematic analysis by Wagner (2010) at Frenchman Mountain, faulting between the LVVSZ and the structural ridge is dominantly reverse or transpressional. Therefore, the cross sections presented in this report project faults exposed at Frenchman Mountain eastward in the subsurface to the line of section A-A' as reverse faults.

- South of the LMFS, section A-A' crosses Patsy Mine volcanic rocks (Tvo) just west of Hoover Dam. Apparent dips indicate a component of dip northward towards the LMFS. These Patsy Mine rocks are dacitic domes and plugs (Tpm, Tpma) that may be less permeable than the volcanic breccias that occur in the unit from Hoover Dam south to Palm Tree Fault.

- South of Palm Tree Fault and the Boulder City pluton, the section transects a highly faulted part of the study area, and parallels several west-dipping normal faults, intersecting Bighorn Fault at the surface and White Rock Fault in the subsurface. The spoon-shape of these faults in the section is caused by slightly curved normal faults dipping toward the viewer. These faults either terminate southward or join a shallow north and west dipping fault that separates volcanic rocks from underlying Proterozoic basement, but also cuts into the basement rocks.

\section{Section B-B'}

Section B-B' extends from the east-tilted Frenchman Mountain block east of the city of Las Vegas southeastward to the Black Mountains (pl. 1). The section crosses the Saddle Island Fault, LMFS system, Frenchman-River Fault, Salt Cedar Fault System, and Kingman Road Fault of Longwell (1963).

- Most of the Paleozoic and the entire Mesozoic section is progressively eroded southeastward from Frenchman Mountain to the southern River Mountains, similar to section A-A'. At the southern end of the River Mountains, Timm (1985) described in situ outcrops of Cambrian Tapeats Sandstone to Muav Limestone that are intruded by stocks and dikes, and overlain by Tertiary volcanic rocks. He concluded younger rocks were erosionally removed on the northern flank of the Kingman uplift prior to extension. In contrast, Triassic and Jurassic sedimentary rocks underlie Tertiary sedimentary rocks in Frenchman Mountain. We infer left-slip on the buried Frenchman River Fault to accommodate the abrupt structural/stratigraphic transition. South of this fault, middle and lower Paleozoic rocks are interpreted based on the occurrence of rocks as young as Mississippian on Wilson Ridge (Longwell, 1963; Anderson and others, 1994).

- The Saddle Island Fault is exposed east of the section line and dips west beneath the River Mountains from Saddle Island to the LMFS. North of Saddle Island, the fault is shown to dip northward (Duebendorfer and others, 1990; Anderson and Beard, 2010).

- The Hemenway Wash Fault strand of the LMSF most likely has multiple strands buried by Quaternary deposits. Isolated bedrock outcrops in the wash are of highly brecciated and sericite- and kaolin-altered porphyritic rock caught in the fault zone (Longwell, 1936). South of the LMFS, the section crosses the Boulder City pluton, parts of which are intensely sheared or brecciated, or both. The Salt Cedar Fault occurs near the southeast boundary of the pluton and is intruded and overlapped by dacite and associated volcaniclastic rocks of the upper Mount Davis Volcanics (Tvy, Tvyi). To the east, the west-dipping White Rock Fault runs parallel to the section for about 2 $\mathrm{km}$, as shown by the shallow apparent dip, before diverging from the section line-hence the apparent steepening dip of the fault. The White Rock Fault intersects the Salt Cedar Fault Zone because of the shallower dip.

- East of the White Rock Fault, the section shows a faulted syncline-anticline pair involving Patsy Mine and Mount Davis volcanic rocks (Tvo and Tvy). The faulted syncline is partially exposed but the anticline is mostly controlled by projecting faults and dips of rocks into the section from the south (Anderson, 1978). The volcanic rocks are overlain by Tertiary conglomeratic sediments, including the large megabreccia slide block composed of crystalline rock derived from Wilson Ridge. Following Anderson (1978), the section portrays a broad shallow syncline beneath the sedimentary rocks between Black Canyon and Wilson Ridge. The Kingman Road Fault of Longwell (1963) on the western side of the Black Mountains is not exposed but is most likely a moderate to steep west-dipping fault.

\section{Section C-C'}

Section C-C' crosses from the relatively unextended volcanic rocks of the northern McCullough Range east across the LMFS (Black Hills Fault) and the northern tip of Eldorado Valley (pl. 1). In Black Canyon, the section intersects the Salt Cedar Fault, northern tip of the Bighorn Fault, and the White Rock Fault. To the east, the section crosses 
the Kingman Road Fault, the Black Mountain horst block, and the Detrital Fault, ending on the eastern side of Detrital Valley.

- Gently to moderately westward tilted volcanic rocks in the McCullough Range (Smith and others, 2010) are cut on the east by normal faults and juxtaposed against Tertiary intrusive rocks (Ti; Railroad Pass Pluton).

- Eldorado Valley is bounded on the east and west by oblique left-slip faults; south of the section, the Black Hills Fault has Quaternary normal separation (Fossett, 2005). In contrast, an unstudied fault on the eastern side of the valley and south of Boulder City (Ekren and Anderson, 1996), herein called the Powerline Fault, shows no Quaternary offset.

- Between the Powerline and Salt Cedar Faults, westside-down normal faults cut the Boulder City pluton (Ti) and unconformably overlying Patsy Mine and Mount Davis volcanic rocks (Tvo and Tvy). The Boulder City pluton is not mapped to the east or south of Salt Cedar Fault, and the fault presumably cuts along or near the margin of the pluton. The section shows an intrusive mass of younger Mount Davis dacite (Tvyi) that probably both intruded along and was cut by the Salt Cedar Fault. The lozenge-shaped outcrop of Proterozoic crystalline rock within the fault zone is bounded on the east by a dike of the dacite that intruded along a strand of the fault zone. The strand, exposed south of the section, is east-sidedown, but may originally be a west-side-down normal fault with slip reversed synchronous with dacite intrusion. The extent of the Proterozoic fault block in the subsurface is unknown, but the depth-to-bedrock anomaly model of Langenheim and others (2010) indicates crystalline basement may be no more than 100-300 m below surface. Therefore, Proterozoic rock is mostly likely at shallow depths in the subsurface between the fault block and basement exposures about $4 \mathrm{~km}$ south.

- West-dipping faults bounding east-tilted fault blocks of Patsy Mine Volcanics (Tvo) underlie Black Canyon along the river; eastward the section crosses the Bighorn Fault and the east-bounding fault of the White Rock-Arizona half-graben, which becomes a full-graben about a kilometer to the north.

- Section C-C' mimics cross section A-A' of Anderson (1978) in showing a gentle faulted syncline between Black Canyon and the Black Mountains with a steep upturning of Patsy Mine volcanic rocks against the Kingman Road Fault that are overlapped unconformably by Mount Davis volcanic rocks. The rocks are displaced by east-side down normal faults antithetic to the Kingman Wash Fault. Multiple strands of the Kingman Road Fault cut the west side of the Black Mountains.

- Detrital Valley is an east-tilted graben that is bounded by the Detrital Fault on the west and an unnamed fault to the east (Beard and others, 2011b). The depthto-bedrock anomaly model of Langenheim and others (2010) indicates the valley contains about $600 \mathrm{~m}$ of basin-fill. No well logs are available along the line of section in Detrital Valley, but $1-3 \mathrm{~km}$ to the south wells penetrate evaporite deposits, including halite at about $50 \mathrm{~m}$ below the surface (Tsmy; Beard and others, 2011b). Volcanic rocks at the surface on the east side of the valley are not exposed on the west but most likely occur in the subsurface.

\section{Section D-D'}

Geologic features intersected by section D-D' include the southern and northern Eldorado Basin and the bounding faults, geologic units, and faults (including the Palm Tree Fault) surrounding Hoover Dam, Fortification Hill basalt, Wilson Ridge pluton in the northern Black Mountains, and Boulder Wash Fault of Longwell (1963).

- The subsurface geology of Eldorado Valley is highly interpretive because of a lack of both surface and subsurface geologic control. The depth-to-bedrock anomaly model of Langenheim and others (2010) indicates two basins that are most likely structurally controlled. A southern basin lies mostly to the east of the section line and is more than $2 \mathrm{~km}$ deep. The northern basin, transected on its eastern edge by the cross section, models to about $1.5 \mathrm{~km}$ deep (Langenheim and others, 2010). The footwall of the west-side-down Keyhole Fault separates the two basins. The Black Hills Fault (not crossed by section) and the left-oblique Powerline Fault are the west and east bounding structures to the northern basin, respectively. Only the northern end of Dry Lake playa (QTpf, pl. 1) overlies the deepest part of northern subbasin, whereas the southern end overlaps the bedrock high between the two basins.

- The portrayal of multiple faults cutting volcanic rocks below the northern basin is based on mapping in the Eldorado Mountains south of the section that indicates extensive faulting and tilting of, and development of angular unconformities between and within, the Patsy Mine and Mount Davis rocks (Anderson, 1971). Section D-D' attempts to model decreasing amounts of faulting and tilting northward within Eldorado Valley.

- The geology at Hoover Dam is well controlled, and the section shows closely spaced faults bounding 
east-tilted blocks of volcanic rocks on the east side of the Boulder City pluton. Numerous faults, not all shown on cross section, dip 20-65 degrees west, and are cut by steeper strike-slip faults (Angelier and others, 1985), one of which crosses the river at the downstream portals (fig. 3; shown on the cross section). During cross-section construction, fault displacement and dip was balanced so that rock units maintained roughly the same elevation below and above the dam. The Dam conglomerate (not shown on section; see Tdc, fig. 2) is located at river level from $400 \mathrm{~m}$ upstream to at least $600 \mathrm{~m}$ downstream from the dam (Bureau of Reclamation, 1950). The Dam conglomerate is as much as $500 \mathrm{~m}$ thick at the dam. At about $800 \mathrm{~m}$ upstream of Hoover Dam, the conglomerate thins rapidly to about $15 \mathrm{~m}$ thick and Patsy Mine volcanic rocks are exposed at river level (Bureau of Reclamation, 1950; Mills, 1994). Red volcanic sandstones of the Dam conglomerate and the tuff of Hoover Dam (Thd, fig. 2) may be local confining layers, and it is possible the underlying Patsy Mine volcanic breccias are hydrologically confined until the Patsy Mine surfaces below the dam and continues along river level to Palm Tree Fault. In support of this, most of the seeps along river level downstream of the dam are discharging from Patsy Mine rocks or along the contact with the Boulder City pluton.

- East of Hoover Dam, the geology below the volcanic units is unknown. The section shows intersecting plutons (Ti; Boulder City, Paint Pots, or Wilson Ridge), but it is possible the volcanic rocks are underlain by Proterozoic crystalline rocks, or some combination thereof.

- The west-side down Fortification Fault of Longwell (1963) juxtaposes Paint Pots pluton and volcanic rocks against Wilson Ridge pluton. Rogers and Lee (1976) documented earthquake activity on this fault, with fault plane solutions indicating right-lateral slip on the north-striking fault.

- The northern Black Mountains are underlain by Wilson Ridge pluton. The pluton is structurally collapsed in the middle along a north-south zone where the cross section shows east-tilted older volcanic rocks. According to Anderson and others (1994), the volcanic rocks and lower Paleozoic carbonate rocks (north of the section) are intruded by the pluton in this central collapsed zone. On the eastern side of the Black Mountains, the pluton intrudes Proterozoic crystalline rocks; both rock types are dropped down to the east along the Boulder Wash Fault and parallel faults, which form the eastern boundary of the northern Black Mountains.

\section{Summary}

Field observations, geologic mapping, and structural studies indicate that the Palm Tree, Salt Cedar, and White Rock Fault Systems in the Black Canyon study area are the principal hydrogeologic features that influence the distribution of springs downstream of Hoover Dam. Spring locations and elevations suggest the faults either provide lateral hydraulic connectivity or have the same source perpendicular to the fault zone, and local structural discontinuities along the fault zones likely provide conduits for groundwater flow to sufficient depths to achieve observed temperatures of $45-55^{\circ} \mathrm{C}$ commonly encountered in Black Canyon.

Kinematic analysis of faults within the study area indicate that normal faults can be separated into an older north-northwest striking group that predates upper Mount Davis rocks and a younger north-northeast striking group that cuts them. The younger fault set could be Pliocene or younger. A subset of the older normal faults dips moderately and strikes are rotated counterclockwise as much as 60 degrees between Hoover Dam and Hemenway Wash. Strikeslip faults are dominantly northwest-striking right-lateral faults and northeast-striking left-lateral faults, but include east-west striking faults that at least partly result from rotation and overprinting of the first two groups, and a small north-striking subset that may represent young reactivation of older faults. Field studies and kinematic analysis did not reveal obvious age-faulting relations for the strike-slip faults. The modern northwest-southeast direction of extensional stress suggests that faults oriented north to northeast would be under relative tension and those oriented northwest under relative compression. The load and hydraulic effect of filling Lake Mead may have caused earthquakes and enhanced hydraulic connectivity between the lake and regional faults and fracture systems. The seismic activity and increased pore pressure may act to reopen fractures. We suggest that very young or seismically active faults and fractures are most likely to have greatest effect on groundwater flow and spring discharge, at least near Lake Mead.

The regional-scale cross sections indicate that the Paleozoic carbonate-rock aquifer of southeastern Nevada (Page and others, 2005) does not extend south of the Saddle Island Fault except for faulted Cambrian carbonate and clastic rocks intruded by Tertiary intrusive rocks in the southern River Mountains, where they are unlikely to contribute to regional flow. The sections are consistent with an interpretation that carbonate aquifer rocks from north to south are terminated at the northeast-striking LMFS and the northwest-striking LVVSZ which combine to form a major tectonic boundary. Southerly flow paths are restricted by the presence of intrusive rocks and by this tectonic boundary. At a smaller scale, a complex fault system west of Black Canyon strikes dominantly north-south, suggesting convoluted pathways that may inhibit east-west groundwater movement. 
In addition, the depth-to-bedrock anomaly model of Langenheim and others (2010) indicates crystalline basement rock may be as shallow as $100-300 \mathrm{~m}$ below the surface. These same faults could be conducive to groundwater flow along north-south structures. To the east of Black Canyon, the massive and relatively unfaulted Proterozoic rocks in the Black Mountains are bounded by steep north-south normal faults and also probably inhibit westerly groundwater movement from Detrital Valley to the spring discharge area in Black Canyon.

Near Hoover Dam, subsurface-flow paths between Lake Mead and the thermal springs discharging in Black Canyon may be inhibited between the dam and Hemenway Wash by (1) fault planes and volcanic rocks in this area rotated to westerly strikes, (2) the probable low-permeability of the dacitic middle Patsy Mine volcanic rocks, and (3) highly altered and therefore probably low-permeability rocks in the LMFS in Hemenway Wash. Groundwater flow beneath the dam is possible, if the lake water infiltrates highly fractured Patsy Mine volcanic rocks upstream of Hoover Dam and the hydraulic head of the lake drives groundwater flow through Patsy Mine rocks beneath the dam. Finally, the cross sections indicate that Proterozoic basement rocks or Tertiary plutonic rocks, or both, are at most a few hundred meters below the surface where they are cut by faults in the Black Canyon. Field observations, geologic mapping, and kinematic fault analysis suggest these faults could provide pathways for groundwater movement at sufficient depths to account for the temperature and chemistry of the springs, in preference to a model that accounts for these features by groundwater interaction with a local magmatic heat source, as proposed by McKay and Zimmerman (1983).

\section{References Cited}

Allmendinger, R.W., 1989, Notes on fault slip analysis: Geological Society of America Short Course Notes, Quantitative Interpretation of Joints and Faults, 56 p.

Allmendinger, R.W., Marrett, R.A., and Cladouhos, T., 2011, FaultKin v. 5.0-A program for analyzing fault-slip data on a Macintosh computer: Absoft Corp., 1988-2004.

Anderson, L.W., and O'Connell, D.R., 1993, Seismotectonic study of the northern portion of the Lower Colorado River, Arizona, California, and Nevada: Bureau of Reclamation Seismotectonic Report 93-4, 122 p., 3 sheets.

Anderson, R.E., 1969, Notes on the geology and paelohydrogeology of the Boulder City pluton, southern Nevada, in Geological Survey Research, 1969: U.S. Geological Survey Professional Paper 650-B, p. B35-B40.
Anderson, R.E., 1971, Thin-skin distension in Tertiary rocks of southeastern Nevada: Geological Society of America Bulletin, v. 82, p. 43-58.

Anderson, R.E., 1973, Large-magnitude late Tertiary strikeslip faulting north of Lake Mead, Nevada: U.S. Geological Survey Professional Paper 794, 18 p.

Anderson, R.E., 1977, Geologic map of the Boulder City 15-minute quadrangle, Mohave County, Arizona and Clark County, Nevada: U.S. Geological Survey Geologic Quadrangle Map GQ-1395.

Anderson, R.E., 1978, Geologic map of the Black Canyon 15-minute quadrangle, Mohave County, Arizona and Clark County, Nevada: U.S. Geological Survey Geologic Quadrangle Map GQ-1394.

Anderson, R.E., Barnhard, T.P., and Snee, L.W., 1994, Roles of plutonism, midcrustal flow, tectonic rafting, and horizontal collapse in shaping the Miocene strain field of the Lake Mead area, Nevada and Arizona: Tectonics, v. 13, p. 1,381-1,410.

Anderson, R.E., and Beard, L.S., 2010, Geology of the Lake Mead region: An overview, in Umhoefer, P.J., Beard, L.S., and Lamb, M.A., eds., Miocene tectonics of the Lake Mead region, Central Basin and Range: Geological Society of America Special Paper 463, p. 1-28.

Anderson, R.E., and Laney, R.L., 1975, The influence of Late Cenozoic stratigraphy on distribution of impoundmentrelated seismicity at Lake Mead, Nevada-Arizona: U.S. Geological Survey Journal of Research, v. 3, no. 3, p. 3371-343.

Anderson, R.E., Longwell, C.R., Armstrong, R.L., and Marvin, R.F., 1972, Significance of K-Ar ages of Tertiary rocks from the Lake Mead region, Nevada-Arizona: Geological Society of America Bulletin, v. 83, p. 273-288.

Anderson, Z.W., and Beard, L.S., 2011, Structural and kinematic analysis of Miocene rocks, Black Canyon, Arizona and Nevada: Geological Society of America Abstracts with Program, v. 43, no. 4, p. 82.

Angelier, J., Colletta, B., and Anderson, R.E., 1985, Neogene paleostress changes in the Basin and Range-A case study at Hoover Dam, Nevada-Arizona: Geological Society of America Bulletin, v. 96, p. 347-361.

Beard, L.S., Anderson, R.E., Block, D.L., Bohannon, R.G., Brady, F.J., Castor, S.B., Duebendorfer, D.M., Faulds, J.E., Felger, T.J., Howard, K.A., Kuntz, M.A., and Williams, V.S., 2007, Preliminary geologic map of the Lake Mead 30 ' x 60' quadrangle, Clark County, Nevada, and Mohave County, Arizona: U.S. Geological Survey Open-File Report 2007-1010, scale 1:100,000. 
Beard, L.S., Anderson, Z.W., and Felger, T.J., 2011a, Structural controls on thermal springs in Black Canyon, Arizona and Nevada: Geological Society of America Abstracts with Program, v. 43, no. 4, p. 83.

Beard, L.S., and Faulds, J.E., 2010, Kingman uplift, paleovalleys, and extensional foundering in northwest Arizona, in Beard, L.S., Karlstrom, K.E., Young, R.A., and Billingsley, G.H., eds., CRevolution 2-Origin and evolution of the Colorado River system, workshop abstracts: U.S. Geological Survey Open-file Report 20111210, p. 28-32.

Beard, L.S., Kennedy, J., and Felger, T.J., 2011b, Geologic map of Detrital, Hualapai, and Sacrament Valleys and surrounding areas, Northwest Arizona: U.S. Geological Survey Open-File Report 2011-1225, 79 p., 250,000-scale map.

Bell, J.G., and Smith, E.I., 1980, Geologic map of the Henderson quadrangle, Nevada: Nevada Bureau of Mines and Geology Map 67, scale 1:24,000.

Bohannon, R.G., 1983, Geologic map, tectonic map and structure sections of the Muddy and northern Black Mountains, Clark County, Nevada: U.S. Geological Survey Miscellaneous Investigations Series I-1406, scale 1:62,500.

Bohannon, R.G., 1984, Nonmarine sedimentary rocks of Tertiary age in the Lake Mead region, southeastern Nevada and Northwestern Arizona: U.S. Geological Survey Professional Paper 1259, 72 p.

Bureau of Reclamation, 1950, Boulder canyon project final reports-Part III: Denver, Colorado Geologic Investigations: Bulletin 1, $232 \mathrm{p}$.

Cakir, M., Aydin, A., and Campagna, D.J., 1998, Deformation pattern around the conjoining strike-slip fault systems in the Basin and Range, southeast Nevada - The role of strike-slip faulting in basin formation and inversion: Tectonics, v. 17, p. 344-359.

Carder, D.S., 1945, Seismic investigation in the Boulder Dam area, 1940-1944, and the influence of reservoir loading on earthquake activity: Bulletin of the Seismological Society of America, v. 35, p. 175-192.

Castor, S.B., Faulds, J.E., Rowland, S.M., and dePolo, C.M., 2000, Geologic map of the Frenchman Mountain quadrangle, Clark County, Nevada: Nevada Bureau of Mines and Geology Map 127, scale 1:24,000.

Dinwiddie, C.L., Bradbury, K.K., McGinnis, R.N., Stillman, D.E., and Ferrill, D.A., 2012, Hydrogeologic heterogeneity of faulted and fractured Glass Mountain bedded tuffaceous sediments and ash-fall deposits-The crucifix site near Bishop, California: Lithosphere, v. 4, p. 40-62.
DigitalGlobe, 2006, Quickbird scenes 005557296010 , 005558591020, 005558679010, 005558591010, 005558591030, 005558591040, 005562053020, 005562053030, 005562053040, 005573382030, 005562053010, 005562053050, 005566233010, 005569157010, 005571678020, 005571678010, 005571678030, 005572275010, 005573382010, 005573382020, Standard Geometrically Corrected, Pansharpened: Longmont, Colo., DigitalGlobe, Inc.

Duebendorfer, E.M., 2003, Geologic map of the Government Wash quadrangle, Nevada: Nevada Bureau of Mines and Geology Map 140, scale 1:24,000.

Duebendorfer, E.M., Beard, L.S., and Smith, E.I., 1998, Restoration of Tertiary deformation in the Lake Mead region, southern Nevada - The role of strike-slip transfer faults, in Faulds, J.E., and Steward, J.H., eds., Accommodation zones and transfer zones-The regional segmentation of the Basin and Range Province: Boulder, Colorado, Geological Society of America Special Paper 323, p. 127-148.

Duebendorfer, E.M., Chamberlain, K.R., Jones, C.S., 2001, Paleoproterozoic tectonic history of the Mojave-Yavapai boundary zone-Perspective from the Cerbat Mountains, northwestern Arizona: Geological Society of America Bulletin, v. 113, p. 575-590.

Duebendorfer, E.M., Sewall, A.J., and Smith, E.I., 1990, The Saddle Island detachment-An evolving shear zone in the Lake Mead area, Nevada: in Wernicke, B.P., ed., Basin and Range extensional tectonics near the latitude of Las Vegas, Nevada: Boulder Colorado, Geological Society of America Memoir 176, p. 77-97.

Duebendorfer, E.M., and Simpson, D.A., 1994, Kinematics and timing of Tertiary extension in the western Lake Mead region, Nevada: Geological Society of America Bulletin, v. 106, p. 1,057-1,073.

Eaton, G.P., 1982, The Basin and Range province-Origin and tectonic significance: Annual Review of Earth and Planetary Sciences, v. 10, p. 409-440.

Ekren, E.B., and Anderson, R.E., 1996, Preliminary geologic map of the Boulder City 7 1/2-minute quadrangle, Clark County, Nevada: Map prepared for the Las Vegas Valley Water District, pamphlet, $13 \mathrm{p}$, map scale 1:24,000.

Environmental Systems Research Institute, Inc., 2009, ArcScene [GIS software], Version 9.3.1: Redlands, Calif., http://www/esri/com/software/arcgis/index.htm/.

Faugére, E., 1985, La Tectonique en extension intracontinentale etude de terrain (le sub du Nevada, U.S.A.), et modélisation analogique: Diplome de Docteur, à l' Université Pierre et Marie Curie, 194 p. 
Faulds, J.E., Feuerbach, D.L., Miller, C.F., and Smith, E.I., 2001, Cenozoic evolution of the northern Colorado River extensional corridor, southern Nevada and northwest Arizona: Pacific Section of the American Association of Petroleum Geologists Publication GB 78 (also Utah Geological Association Publication 30), p. 239-272.

Faulds, J.E., Olson, E.L., Harlan, S.S., and McIntosh, W.C., 2002, Miocene extension and fault-related folding in the Highland Range, southern Nevada-A three-dimensional perspective: Journal of Structural Geology, v. 24, p. 861-886.

Faulds, J.E., Smith, E.I., and Gans, P., 1999, Spatial and temporal patterns of magmatism and extension in the Northern Colorado River Extensional Corridor, Nevada and Arizona-A preliminary report: Nevada Petroleum Society Field Trip Guidebook, Nevada Petroleum Society, Reno, p. 171-183.

Faunt, C.C., 1997, Effect of faulting on ground-water movement in the Death Valley region, Nevada and California: U.S. Geological Survey Water Resources Investigations Report 95-4132, 42 p.

Felger, T.J., and Beard, L.S., 2010, Geologic map of Lake Mead and surrounding regions, southern Nevada, southwestern Utah, and northwestern Arizona, in Umhoefer, P.J., Beard, L.S., and Lamb, M.A., eds., Miocene tectonics of the Lake Mead region, Central Basin and Range: Geological Society of America Special Paper 463, p. 29-38, 1 sheet.

Felger, T.J., Beard, L.S., Anderson, Z.W., Fleck, R.J., Wooden, J.L., and Seixas, G.B., 2014, Preliminary geologic map of Black Canyon study area, Nevada and Arizona: U.S. Geological Survey Open-File Report 2013-1267A, scale $1: 48,000$.

Flesch, L.M., and Kreemer, C., 2010, Gravitational potential energy and regional stress and strain rate fields for continental plateaus-Examples from the central Anders and Colorado Plateau: Tectonophysics, v. 482, p. 182-192.

Fossett, E., 2005, Paleoseismicity of the Black Hills fault, southern Nevada, and implications for regional tectonics: Las Vegas, University of Nevada, M.S. thesis, 96 p.

Gans, P.B., and Bohrson, 1998, Suppression of volcanism during rapid extension in the Basin and Range Province, United States: Science, v. 279, p. 66-68.

Geissman, J.W., Hudson, M.R., Faulds, J.E., Callian, J.T., Harlan, S.S., Huang, Q., and Li, Y., 1989, Paleomagnetic research in the Basin and Range province, western United States-Historical perspective, applications, and limitations, in Ellis, M.A., ed., Late Cenozoic Evolution of the Southern Great Basin: Nevada Bureau of Mines and Geology OpenFile Report 9-1, p. 87-97.
Goetz, A.F.J., Billingsley, F.C., Gillespie, A.R., Abrams, M.J., Squires, R.L., Shoemaker, E.M., Lucchitta, I., and Elston, D.P., 1975, Application of ERTS images and image processing to regional geologic problems and geologic mapping in northern Arizona: Jet Propulsion Laboratory Technical Report 32-1597, 188 p.

Hammond, W.C., and Kreemer, C., 2008, Estimating seismic hazard in the Basin and Range Province using horizontal GPS DATA — Collaborative research between the University of Nevada, Reno and the USGS: Final Technical Report Award Number 07HQGR0027, 14 p.

Honn, D.K., and Smith, E.I., 2010, The mid-Miocene Wilson Ridge pluton and River Mountains volcanic section, Lake Mead area of Nevada and Arizona_-Linking a volcanic and plutonic section, in Duebendorfer, E.M., and Smith, E.I., eds., Field guide to plutons, volcanoes, faults, reefs, dinosaurs, and possible glaciation in selected areas of Arizona, California, and Nevada: Geological Society of America Field Guide 11, p. 1-20.

Honn, D.K., Smith, E.I., Simon, A., and Spell, T.L., 2010, Redefining an igneous system-Magmatic evolution of the River Mountains volcanic suite and Wilson Ridge pluton: Geological Society of America Abstracts with Programs, v. 42 , no. 4 , p. 51 .

Justet, L., and Beard, S., 2010, The role of transtensional structures and Lake Mead Reservoir in groundwater flow in Black Canyon, Lake Mead National Recreation Area, NV-AZ: American Geophysical Union Abstracts, \#H21B-1033.

Justet, L., Paces, J.B., and Beard, L.S., 2011, Determining the localized nature of groundwater flow in Black Canyon below Hoover Dam using geochemical, geologic and kinematic approaches, Lake Mead National Recreation Area, Nevada-Arizona: Nevada Water Resources Association 2011 Annual Conference, p. 34, accessed on June 13, 2013, at http://www.nvwra.org/ storage/2011/2011Conf_FinalProgram.pdf.

Langenheim, V.E., Beard, L.S., and Faulds, J.E., 2010, Implications of geophysical analysis on basin geometry and fault offsets in the northern Colorado River extensional corridor and adjoining Lake Mead region, Nevada and Arizona, in Umhoefer, P.J., Beard, L.S., and Lamb, M.A., eds., Miocene tectonics of the Lake Mead region, Central Basin and Range: Geological Society of America Special Paper 463, p. 39-59.

Langenheim, V.E., Grow, J.A., Jachens, R.C., Dixon, G.L., and Miller, J.J., 2001, Geophysical constraints on the location of geometry of the Las Vegas Valley shear zone, Nevada: Tectonics, v. 20, p 189-209. 
Langenheim, V.E., and Schmidt, K.M., 1996, Thickness and storage capacity of basin fill of the northern part of the Eldorado Valley, Nevada, and the extent of the Boulder City pluton: U.S. Geological Survey Open-File Report 96-512, $27 \mathrm{p}$.

Longwell, C.R., 1936, Geology of the Boulder Reservoir floor, Arizona-Nevada: Geological Society of America Bulletin, v. 47 , p. $1,393-1,476$.

Longwell, C.R., 1963, Reconnaissance geology between Lake Mead and Davis Dam, Arizona-Nevada: U.S. Geological Survey Professional Paper 374-E, 47 p., 1 plate.

McKay, W.A., and Zimmerman, D.E., 1983, Hydrogeochemical investigation of thermal springs in the Black Canyon-Hoover Dam area, Nevada and Arizona: University of Nevada, Desert Research Institute publication 41092, $40 \mathrm{p}$.

Marrett, R., and Allmendinger, R.W., 1990, Kinematic analysis of fault-slip data: Journal of Structural Geology, v. 12, p. 973-986.

Maurer, D.K., Lopes, T.J., Medina, R.L., and Smith, J.L., 2004, Hydrogeology and hydrologic landscape regions of Nevada: U.S. Geological Survey Scientific Investigations Report 2004-5131, $41 \mathrm{p}$.

Meade, R.B., 1985, Hoover Dam earthquakes reconsidered, in Roluti, M.J., ed., Waterpower '85, Proceedings of an International Conference on Hydropower, Las Vegas, Nevada; v. 3, p. 1,308-1,315.

Mills, J.G., Jr., 1985, The geology and geochemistry of volcanic and plutonic rocks in the Hoover Dam 7 1/2 minute quadrangle, Clark County, Nevada and Mohave County, Arizona: Las Vegas, University of Nevada, M.S. thesis, 119 p.

Mills, J.G., 1994, Geologic map of the Hoover Dam quadrangle, Arizona and Nevada: Nevada Bureau of Mines and Geology, Map 102, scale 1:24,000.

Page, W.R., Scheirer, D.S., and Langenheim, V.E., 2005, Geologic cross sections of parts of the Colorado, White River, and Death Valley regional ground-water flow systems, Nevada, Utah, and Arizona: U.S. Geological Survey OpenFile Report 2006-1040, 23 p, 1 plate.

Patton, H.J., and Zandt, George, 1991, Seismic moment tensors of western U.S. earthquakes and implications for the tectonic stress field: Journal of Geophysical Research, v. 96, p. $18,245-18,259$.

Pohlmann, K.F., Campagna, D.J., Chapman, J.B., and Earman, S., 1998, Investigation of the origin of springs in the Lake Mead National Recreation Area: Desert Research Institute, Publication 41161, 83 p.
Rittase, W.M., 2004, Cenozoic extension in the River Mountains and Frenchman Mountain, southern Nevada: University of Nevada, Las Vegas, M.S. thesis, 181 p.

Rogers, A.M., and Lee, W.H.K., 1976, Seismic study of earthquakes in the Lake Mead, Nevada-Arizona region: Bulletin of the Seismological Society of America, v. 66, p. $1,657-1,681$.

Ron, Hagai, Nur, Amos, and Aydin, Atilla, and others, 1993, Rotation of stress and blocks in the Lake Mead, Nevada, fault system: Geophysical Research Letters, v. 20, p. $1,703-1,706$.

Seixas, G.B., and Beard, L.S., 2011, Volcanism, strikeslip faulting and fault rotations near Hoover Dam, Clark County, Nevada: Geological Society of America Abstracts with Program, v. 43, no. 4, p. 83.

Simpson, D.W., Leith, W.S., and Scholz, C.H., 1988, Two types of reservoir-induced seismicity: Bulletin of the Seismological Society of America, v. 78, p. 2,025-2,040.

Smith, K., Depolo, D., Biasi, G., and Anderson, J.G., 2008, Seismicity of the southern Nevada region: Geological Society of America Abstracts with Programs, v. 40, p. 61.

Smith, E.I., 1984, Geologic map of the Boulder Beach quadrangle, Nevada: Nevada Bureau of Mines and Geology Map 81, scale 1:24,000.

Smith, E., Honn, D., and Johnsen, R., 2010, Volcanoes of the McCullough Range, southern Nevada, in Umhoefer, P.J., Beard, L.S., and Lamb, M.A., eds., Miocene tectonics of the Lake Mead region, Central Basin and Range: Geological Society of America Special Paper 463, p. 203-219.

Taylor, W.J., and dePolo, Craig, 2002, Seismic history of the Mead Slope Fault, Southern Nevada: Nevada Earthquake Safety Council Funded Project Report, 1 p., accessed June 13, 2013, at http://www.nbmg.unr.edu/nesc/.

TectonicsFP, 2013, Software for Structural Geology for Microsoft Windows [www.tectonicsfp.com].

Templeton, J.H., and Mills, J.G., Jr., 2005, Insights into shallow emplacement of a mafic dike system, Fortification Hill, northwestern Arizona: Geological Society of America Abstracts with Programs, v. 37, no. 7, p. 291.

Thomas, W.M., Clark, S.H., Young, E.D., Orrell, S.E., and Anderson, J.L., 1988, Proterozoic high-grade metamorphism in the Colorado River region, Nevada, Arizona, and California, in Ernst, W.G., ed., Metamorphism and Crustal Evolution of the Western United States, Rubey Volume VII: Prentice-Hall, Englewood Cliffs, N.J., p. 526-537. 
Timm, J.J., 1985, Age and significance of Paleozoic sedimentary rocks in the southern River Mountains, Clark County, Nevada: Las Vegas, University of Nevada, M.S. thesis, $62 \mathrm{p}$.

Wagner, R.R., 2010, Miocene fault and basin analysis, northern Frenchman Mountain block, Lake Mead domain, Nevada: Flagstaff, Northern Arizona University, M.S. thesis, 217 p.

Williams, M.M., 2003, Depositional history of the Black Mountains conglomerate, Mohave County, ArizonaSedimentary response to Miocene Extension: Las Vegas, University of Nevada, M.S. Thesis, 56 p.

Zoback, M.L., and Zoback, M.D., 1980, State of stress in the conterminous United States: Journal of Geophysical Research, v. 85, p. 6,113-6,156.

\section{Appendix-Kinematic Analysis of Fault Data}

\section{Introduction}

Fault data were collected from 215 sites around the springs of interest in Black Canyon. The data consist of fault-plane strike and dip, rake of striae, and slip-sense where determinable. The commercial program TectonicsFP (http://www.tectonicsfp. com) was used to sort fault data and generate steronet plots and rose histograms presented in the figures of this appendix. Kinematic fault-plane solutions shown in the figures were generated from the fault data using the techniques of Allmendinger (1989) and Marret and Allmendinger (1990) through the freeware program, FaultKinWin (Allmendinger and others, 2011). Striae data collected as rake were converted to trend and plunge for use in both TectonicsFP and FaultKinWin programs.

Kinematic fault-plane solutions are derived from fault slip data, and yield a graphic portrayal of the orientation of the principal axes of average incremental strain, dependent on the assumption of scale invariance of the fault data (see Marrett and Allmendinger, 1990, for in-depth discussion). Bingham distribution statistics provide an objective maxima (Bingham axes) for the respective shortening $(\mathrm{P})$ and extension (T) axes derived for each fault. The kinematic fault-plane solutions presented in this appendix should be viewed as qualitative rather than quantitative because the analysis is based on the assumption of spatial homogeneity of strain, scale invariance of faults, and equal weighting of all fault data. In addition, for this data set an assumption of 'regional default slip' was made in order to assign slip-sense for many faults (see below).

\section{Regional Default Slip}

A key factor in the analysis is that although fault strike, dip, and rake of striaie were measurable on many faults, identification of slip sense in the field is sparse. Because slip sense is a required attribute in kinematic analysis, we assigned directions based on regional faulting patterns of the Lake Mead area - that is, northwest-striking right-lateral faults, northeast-striking left-lateral faults, and northerly-striking normal (rather than reverse) faults (Angelier and others, 1985, Anderson and others, 1994, Duebedorfer and Simpson, 1994, Cakir and others, 1998, Beard and others, 2010). We refer to the direction assignments as "regional default slip" (RDS; fig. 1A). Using the RDS, all faults with striae rakes greater than $45^{\circ}$ (striae rake between $46^{\circ}$ and $134^{\circ}$ ) are defaulted to normal slip (fig. $1 B$ ). Low-rake faults (striae rakes of $0-45^{\circ}$ and $135-180^{\circ}$ ) are split into two groups. Low-rake faults that strike $90^{\circ}-179^{\circ}$ and $270^{\circ}-359^{\circ}$ are defaulted to right-lateral slip as they have the same strike as the right-lateral Palm Tree fault and the northwest-southeast striking Las Vegas Valley shear zone (fig. $1 C$ ). Low-rake faults that strike $0^{\circ}-89^{\circ}$ and $180^{\circ}-269^{\circ}$ are defaulted to left-lateral slip as they have the same strike as the northeast-southwest striking left-lateral Lake Mead Fault System that cuts through the north end of the study area (fig. 1C). Although assigning regional default slip to faults with an unknown slip-sense introduces a large assumption, especially given that 83 percent of our data relies on the default slip, it produces cleaner and more understandable kinematic fault-plane solutions and linked Bingham axes. As an alternative assumption to RDS, we created a kinematic fault-plane solution in which all faults with an unknown sense of slip were defaulted to normal-slip, because the study area is a known extensional province (fig. $2 A$ ). Both the RDS (fig. $1 A$ ) and default-to-normal-slip (fig. $2 A$ ) kinematic fault-plane solutions for all faults contain multiple $\mathrm{P}$ (pressure, or compression) and T-axes (tension, or dilation) axes outside their respective dilational and compressional quadrants, but the RDS results yield a slightly more coherent solution ( $\sim 55$ out of $430 \mathrm{P}$ and $\mathrm{T}$ axes [ $\sim 38 \mathrm{P}$ and $17 \mathrm{~T}]$ lie more than about ten degrees outside the appropriate field in the RDS kinematic fault-plane solution compared to $\sim 60$ outliers [ $\sim 52 \mathrm{P}$ and $8 \mathrm{~T}]$ for default-to-normal-slip solution).

Either result indicates that the faults are not all from a single homogeneous population. The outliers in the RDS plots for all faults probably result from a combination of inhomogeneous populations and true outliers where the assumption of RDS is incorrect. When the data are examined in subsets, the RDS kinematic fault-plane solution for normal faults shows very coherent results with only six outliers of 212 axes ( $\sim 4 \mathrm{~T}$ axes and $2 \mathrm{P}$ axes; fig. $1 B$ ). And, although the RDS results for all low-rake faults are coherent ( $\sim 8 \mathrm{~T}$ and $6 \mathrm{P}$ outliers of 218 axes; fig. $1 C$ ), the default-to-normal results of low-rake faults included $\sim 65$ outliers of 218 axes ( 49 T and $16 \mathrm{P}$ ) and linked Bingham axes with orientations uncharacteristic of regional strain documented by previous work in the area (fig. 2B; Angelier and others, 1985; Anderson and others, 1994; Duebendorfer and Simpson, 1994; Cakir and others, 1998). This supports the application of RDS to the data. Where field evidence contradicted RDS for a few faults such as Salt Cedar Fault (see below), those data were analyzed separately. 


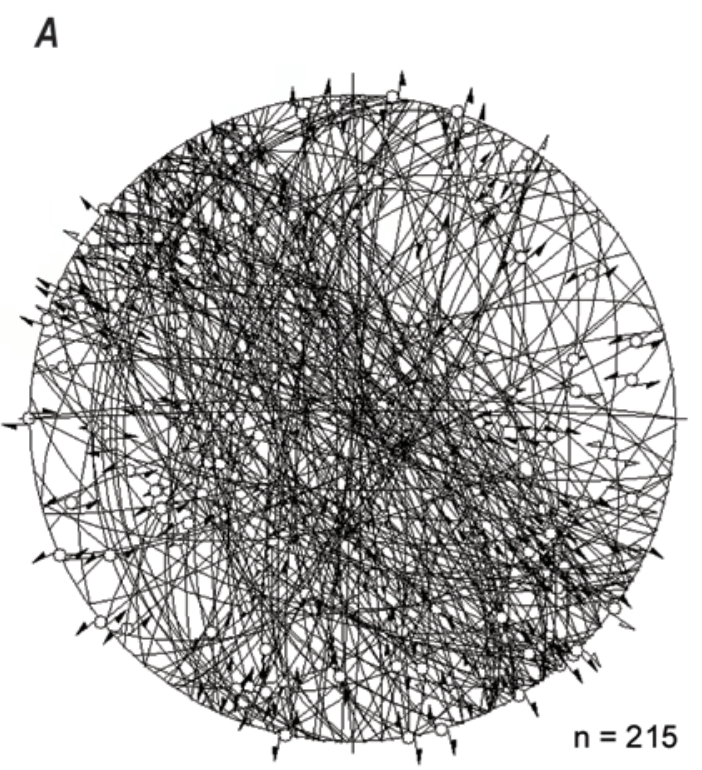

Fault planes

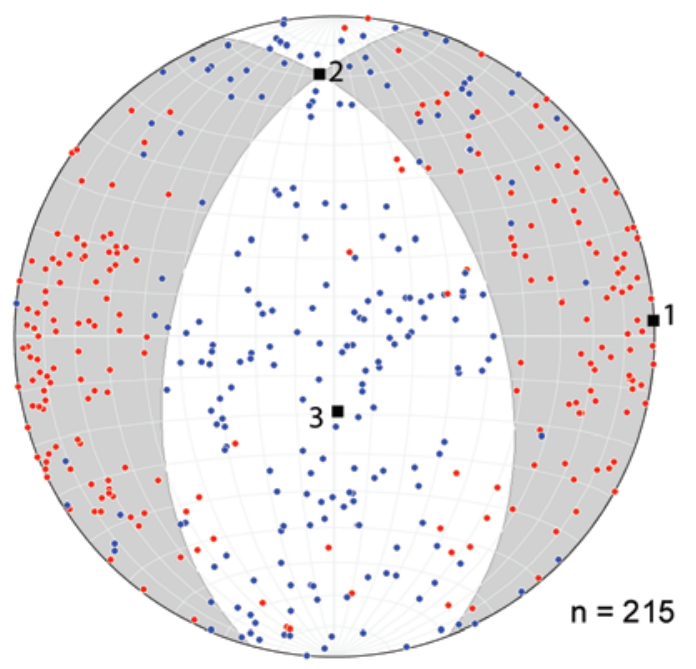

Kinematic fault plane solution

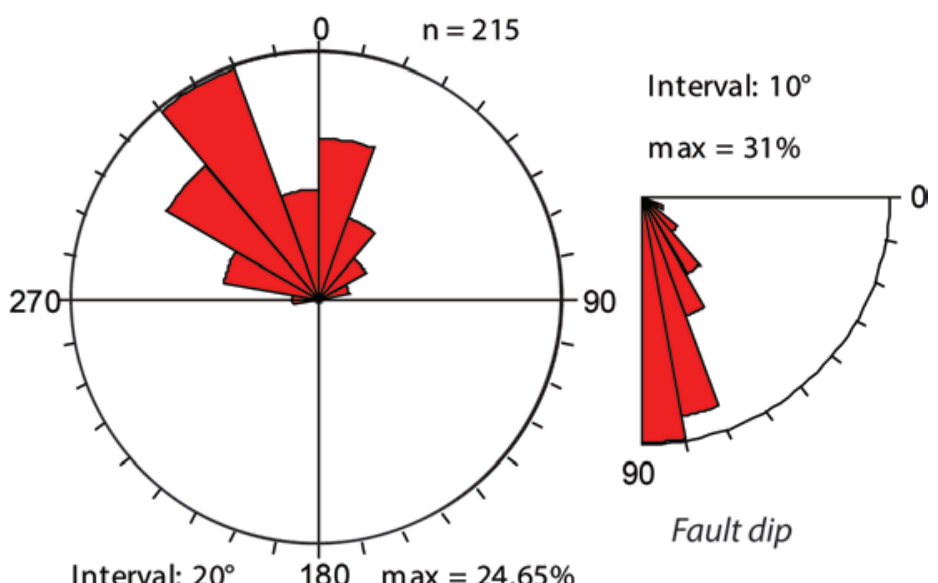

Fault strike

Interval: $10^{\circ}$

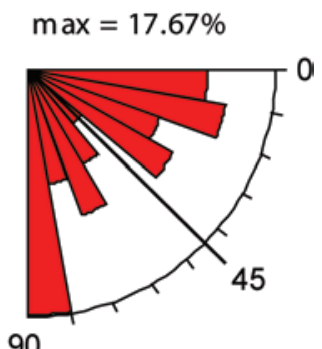

Fault rake

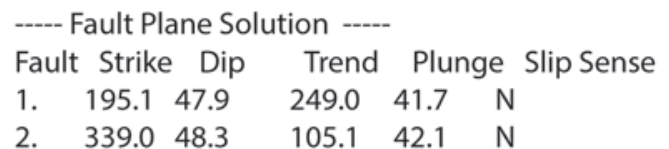

P-axis: 177.6, 71.0; T-axis: 087.0, 00.2

-----Linked Bingham Analysis -----

Axis Eigenvalue Trend Plunge

1. $0.2598 \quad 087.0,00.2$

$\begin{array}{llll}\text { 2. } & 0.1012 \quad 356.9,19.0\end{array}$

Figure A1. Equal-area stereonet plots, rose diagrams, and kinematic fault-plane solutions. Faults were separated into normal or strike-slip based on striae rake of greater than, or less than, or equal to $45^{\circ}$, respectively. Stereonets on upper left are equal-area plots of fault data; circles show striae and arrows show direction of slip based on regional default slip (RDS). Rose histograms on upper right are of fault plane strike and dip. Rose histograms on lower right are of striae rake $(A)$ or striae trend and plunge $(B$ and $C)$. Plot on lower left shows kinematic fault-plane solutions. Shortening (shaded) and extensional (white) quadrants are defined by shortening (T) axes (red dots) and extension (P) axes (blue dots) derived from slip data for individual faults. Black numbered squares show location of linked Bingham axes derived from statistical maxima of $P$ and $T$ axes for each fault set. Bingham axes are numbered as: $1=$ extension axis, $2=$ intermediate axis, and 3 = shortening axis. Orientation of fault planes and Bingham axes shown to right of fault plane solution. $A$, All fault data with regional default slip (RDS). $B$, All normal faults with RDS. Note bimodal distribution of strikes on rose histogram. $C, A l l$ strikeslip faults with RDS. 
B

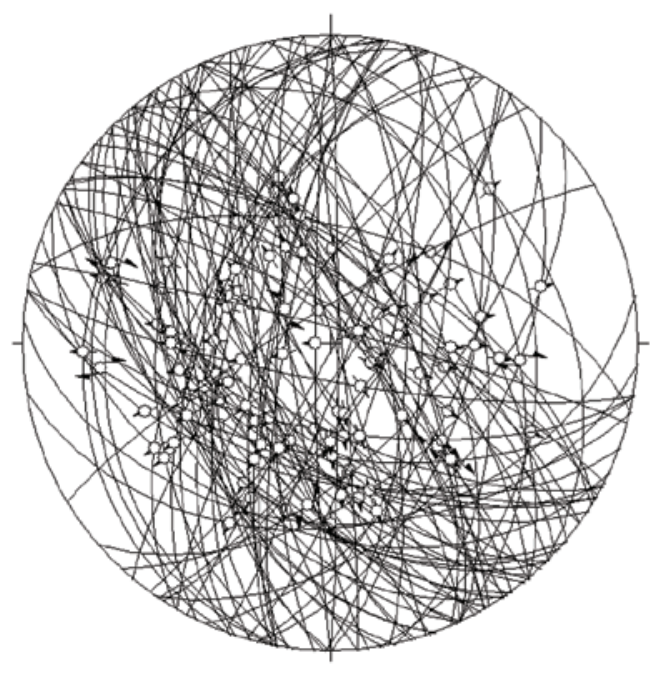

Fault planes

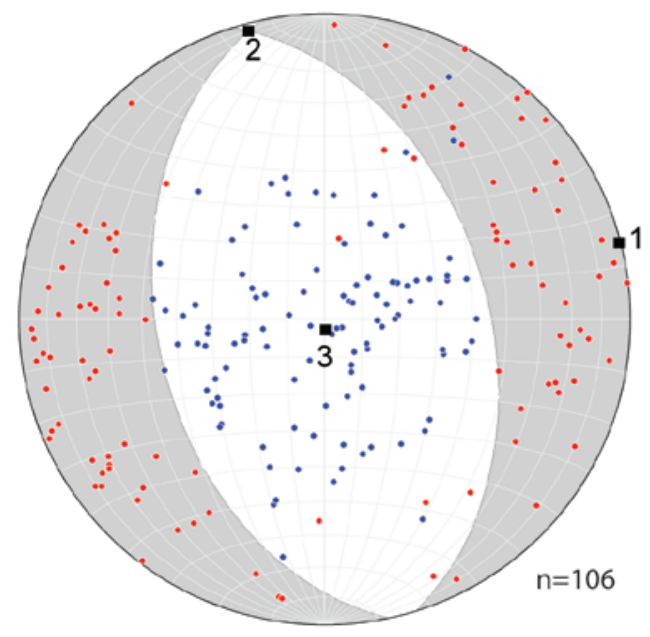

Kinematic fault plane solution
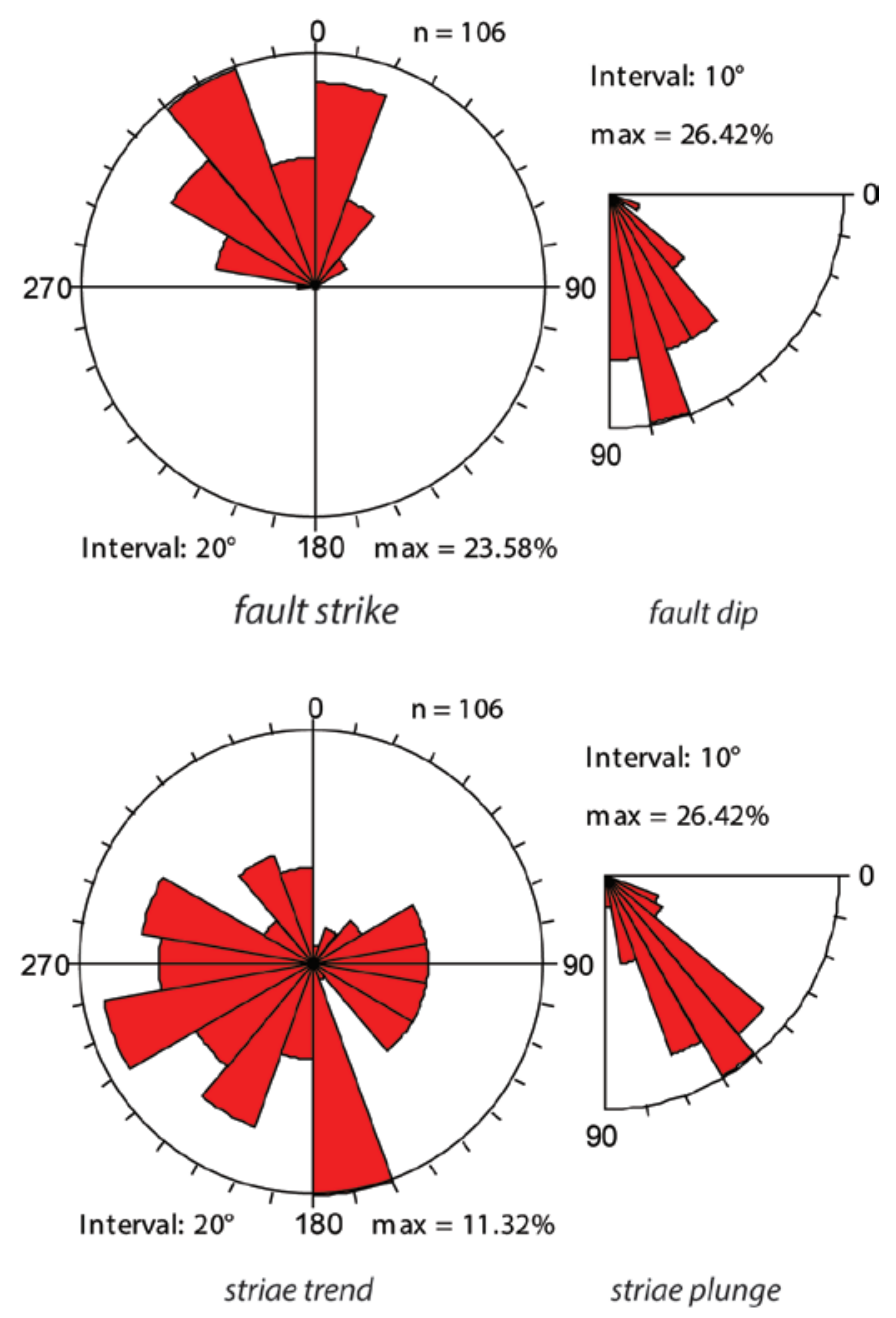

----- Fault Plane Solution --..-

Fault Strike Dip Trend Plunge Slip Sense

$\begin{array}{llllll}1 . & 168.2 & 44.3 & 252.4 & 44.2 & \mathrm{~N}\end{array}$

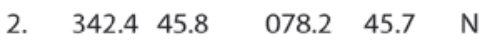

P-axis: $179.9,87.0 ; \quad$ T-axis: $075.3,00.7$

----Linked Bingham Analysis | 12/1/2011 at 3:43 PM----

Axis Eigenvalue Trend Plunge

1. $0.2353 \quad 075.3,00.7$

2. $0.0564 \quad 345.2,02.9$

3. $0.2917 \quad 179.9, \quad 87.0$

Figure A1.-Continued 


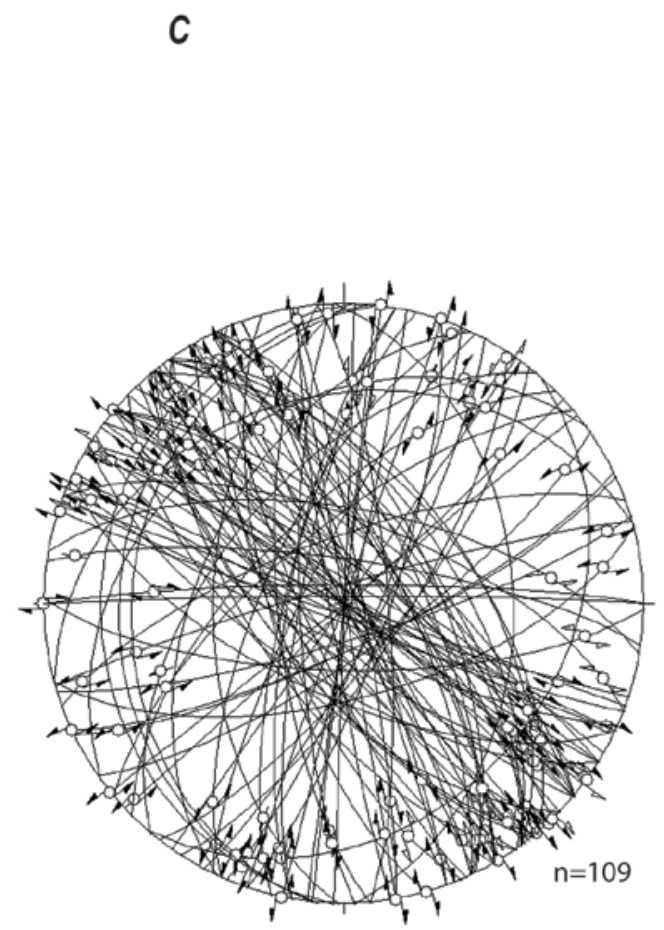

Fault planes
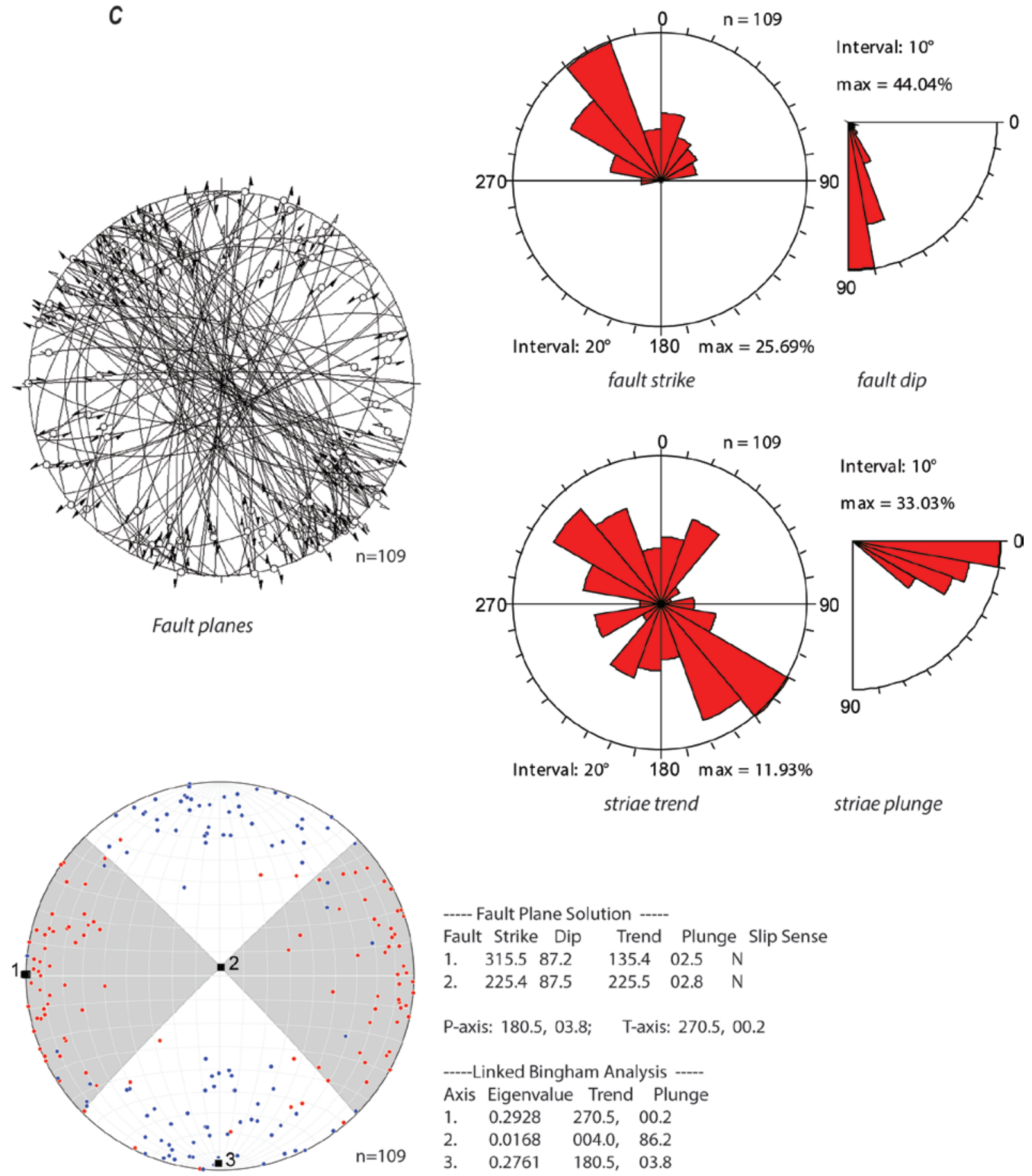

----- Fault Plane Solution -----

Fault Strike Dip Trend Plunge Slip Sense

$\begin{array}{llllll}1 . & 315.5 & 87.2 & 135.4 & 02.5 & \mathrm{~N}\end{array}$

$\begin{array}{llllll}\text { 2. } & 225.4 & 87.5 & 225.5 & 02.8 & \mathrm{~N}\end{array}$

P-axis: 180.5, 03.8; T-axis: $270.5,00.2$

-----Linked Bingham Analysis -----

Axis Eigenvalue Trend Plunge

$\begin{array}{lll}\text { 1. } 0.2928 & 270.5,00.2\end{array}$

$\begin{array}{llll}\text { 2. } & 0.0168 & 004.0, & 86.2\end{array}$

3. $0.2761 \quad 180.5,03.8$

Kinematic fault plane solution

Figure A1.-Continued 


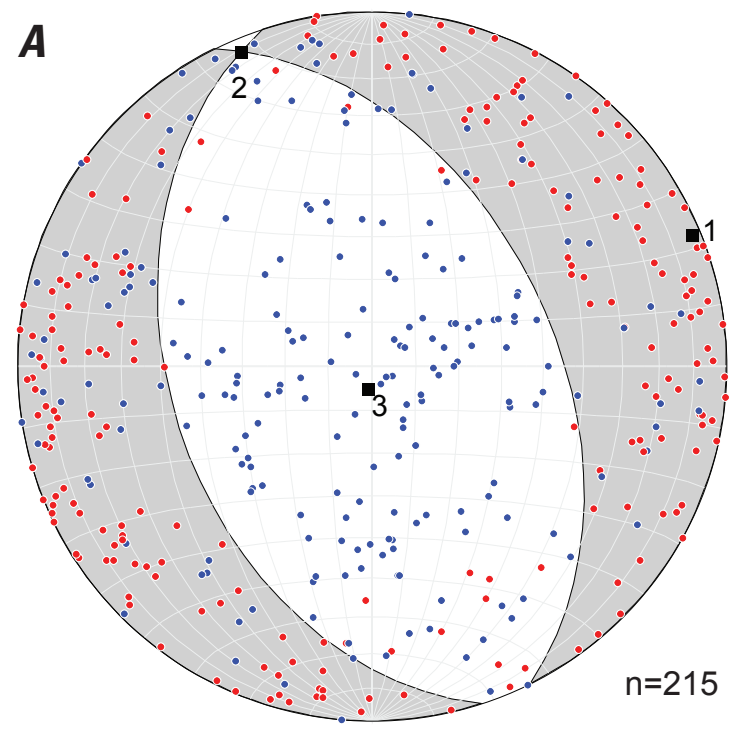

Kinematic fault plane solution

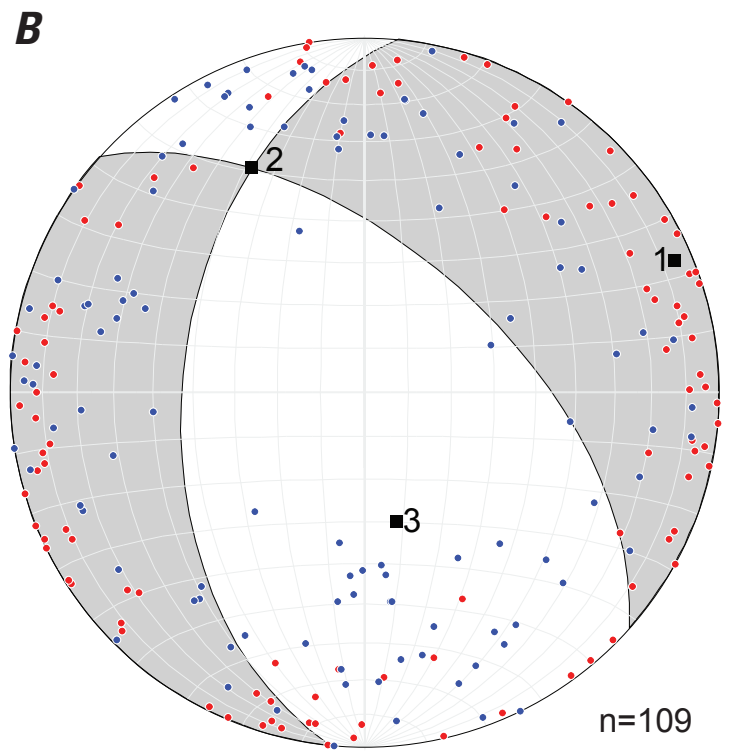

Kinematic fault plane solution
----- Fault Plane Solution -----

Fault Strike Dip Trend Plunge Slip Sense

$\begin{array}{llllll}1 . & 162.1 & 42.4 & 243.6 & 42.1 & \mathrm{~N}\end{array}$

$\begin{array}{llllll}\text { 2. } & 333.6 & 47.9 & 072.1 & 47.6 & \mathrm{~N}\end{array}$

P-axis: $190.4,85.0 ; \quad$ T-axis: $067.6,02.7$

-----Linked Bingham Analysis | 12/1/2011 at 2:42 PM-----

Axis Eigenvalue Trend Plunge

1. $0.1746 \quad 067.6,02.7$

2. $\quad 0.0143 \quad 337.4,04.2$

3. $0.1889190 .4,85.0$
----- Fault Plane Solution -----

\begin{tabular}{llllll} 
Fault Strike Dip & \multicolumn{2}{c}{ Trend } & \multicolumn{2}{c}{ Plunge Slip Sense } \\
1. & 185.5 & 47.4 & 221.7 & 32.6 & $\mathrm{~N}$ \\
2. & 311.7 & 57.4 & 095.5 & 42.6 & $\mathrm{~N}$
\end{tabular}

P-axis: $166.2,59.4 ; \quad$ T-axis: $066.6,05.6$

-----Linked Bingham Analysis | 12/1/2011 at 2:26 PM-----

Axis Eigenvalue Trend Plunge

1. $0.1227 \quad 066.6,05.6$

2. $\quad 0.0389 \quad 333.4, \quad 30.0$

3. $\quad 0.0839 \quad 166.2, \quad 59.4$

Figure A2. Kinematic fault-plane solutions for $(A)$ all faults defaulted to normal. Poor fit of $\mathrm{P}$ (extensional) and $\mathrm{T}$ (compressional) axes to kinematic fault-plane solution suggest either nonhomogeneous populations and (or) that the slip assumptions do not apply to all faults. $B$, Strike-slip faults defaulted to normal. Plot shows poor fit of $\mathrm{P}$ and $\mathrm{T}$ axes to quadrants compared to regional default slip (RDS) kinematic fault-plane solution for strike-slip faults shown in figure 1C. Symbology of the kinematic fault-plane solutions as in figure 1.

\section{Fault Populations}

Because the kinematic fault-plane solutions for all fault data indicated inhomogeneous populations, the data were separated into sub-populations based on field relations. Key field observations are that: (1) younger and older normal fault sets with different average strikes (NNE and NW, respectively) were identified in the Arizona-White Rock graben area, as described in the main text; (2) map relations show that north and northwest-striking normal and strike-slip faults bend counterclockwise west of Hoover Dam and are cut by younger faults with more northerly strikes. The rotated normal faults typically have lower dips than more northerly-striking normal faults. (3) Right-lateral strike-slip faults, such as Palm Tree fault system, are distributed throughout the area, whereas left-lateral strike-slip faults are mostly restricted to the vicinity of the Lake Mead fault system. Strike-slip faults have no discernible age-strike orientation correlation. To make data analysis more manageable, the results are discussed in subsets based on field observations: $1=$ normal faults with dips $\leq 60^{\circ}, 2$ $=$ normal faults with dip $>60^{\circ}$, and $3=$ strike-slip faults. 


\section{Normal Faults}

Normal fault data, defined by striae rake greater than $45^{\circ}$ (fig. $1 B$ ), were analyzed in two groups based on the dip of the fault plane because field mapping indicated a distinct population of moderate to shallow dipping faults with a wide range in strike. These low-angle faults, with dips less than or equal to $60^{\circ}$, form subset 1 (fig. 3). This subset mostly represents extensional faults that accommodated the east tilting of fault blocks, as observed in Goldstrike Canyon and near Hoover Dam, and were possibly tilted as well. Most of these faults dip west to south (subset 1a; fig. $4 A$ ), while fewer dip east (subset $1 \mathrm{~b}$; fig. 5). The west-dipping faults clearly show counterclockwise rotation of fault strikes from south to north, as seen in stereonet plots of the fault planes, rose histograms, and kinematic fault-plane solutions of faults from (1) White Rock Canyon, Arizona Hot Spring, and Bighorn Sheep Canyon (fig. 4b) and (2) Goldstrike Canyon north to Hemenway Wash (fig. $4 C$ ). The most northerly striking faults in the northern group (faults shown with asterick, fig. $4 C)$ are within and kinematically linked to the right-lateral Palm Tree Fault Zone.

East-dipping faults with dips less than or equal to $60^{\circ}$ (subset1b, fig. 5) are mostly located in Arizona and White Rock (AZWR) Canyons; the east-west striking fault in figure 5 was measured along the Lake Mead Fault System to the north and is most likely strongly rotated. The faults (excluding the east-west fault) are separated into a northweststriking set and a north- to northeast-striking set because in AZWR Canyons the former set cuts Patsy Mine Volcanics whereas the latter cuts both Patsy Mine and middle Mount Davis rocks, as discussed in more detail below.

Normal fault subset 2 (fig. 6), which contains highangle normal faults that dip greater than $60^{\circ}$, have a bimodal distribution of northwest and north-northeast strikes. In AZWR Canyons we infer these represent older and younger populations based on field observations. The northwesterly striking faults only cut Patsy Mine Volcanics, whereas the north- northeasterly striking faults cut both Patsy Mine and middle and upper Mount Davis rocks, and are therefore inferred to be younger. A plot of all faults measured within the Mount Davis rocks of the AZWR graben (fig. 7A) shows a north-northeast-striking graben pattern and conjugate faults dipping both east and west. A plot of all north-northeaststriking normal faults measured in AZWR Canyons (fig. 7B) and the kinematic fault-plane solution shows a very similar conjugate pattern to that of the AZWR graben (fig. 7C), suggesting that some of the faults in the Patsy Mine Volcanics adjacent to the graben are of the same younger generation. Combining both the east- and west-dipping faults with dips less than $60^{\circ}$ from AZWR Canyons shows a similar pattern (fig. $7 \mathrm{C}$ ), suggesting the older northwest-striking faults also reflect graben-style conjugate faulting, but with a northwest strike about $40^{\circ}$ counterclockwise to the younger faults. The kinematic fault-plane solutions with no outlier P-T axes support this interpretation (fig 7). The conjugate fault pattern is not observed in the north part of the study area; the style of faulting there is of an asymmetric west-side-down domino fault pattern. We suggest the older north-northwest-striking, high-angle normal faults were formed during the latest stages of the older faulting event represented by the lower dip normal faults (subset 1) and at least partly postdate tilting.

\section{Strike-Slip Faults}

Strike-slip faults show a wide range in strikes and are nearly vertically dipping and strongly strike-slip (subset 3; fig. 1C). For analysis, the faults were separated into four strike subsets - northwest, northeast, east-west, and north (fig. 8). There is no noticeable difference in strike of subset 3 faults between the northern part of the study area and AZWR and Bighorn Sheep Canyons. Northwest-striking faults are dominant (fig. $8 \mathrm{~A}$ ) and we infer right-lateral slip using the known right-lateral sense of the northwest-striking Palm Tree Fault Zone and the assumption of RDS. Palm Tree Fault Zone forms the longest mappable right-lateral fault zone within the study area. Other right-lateral faults are distributed throughout the study area, forming short en echelon fault segments that are not always mappable at 1:24,000-scale. Northeast-striking lateral-slip faults (fig. $8 \mathrm{~A}$ ) are assumed to be left-lateral based on a limited number of sense-of-slip measurements and regional default slip. Like the right-lateral faults, they are distributed throughout the study area and are typically short en echelon fault segments. The only major left-lateral faults mapped within the study area are at the far northern end of the study area and are part of the Lake Mead Fault System.

East-west striking strike-slip faults (fig. 8B) occur throughout the study area. The poor fit to the kinematic fault-plane solutions are probably due to both the low number of data sets and the complex pattern of faulting and rotation. Slip sense on the faults includes left-lateral, rightlateral, and unknown. Eight of the east-west strike-slip faults were measured at the north end of the study area within the zone of counterclockwise rotation (fig. 9; Seixas and Beard, 2011). The remainder were measured in AZWR Canyons.

Discontinuous northerly-striking faults (fig. $8 \mathrm{C}$ ) that show strike-slip striae in AZWR and Bighorn Sheep Canyons, similar to Salt Cedar Fault in Goldstrike Canyon, which exhibits right-slip striae and right-sense offset of the canyon. These faults may be reactivated normal faults or young right-lateral faults. 


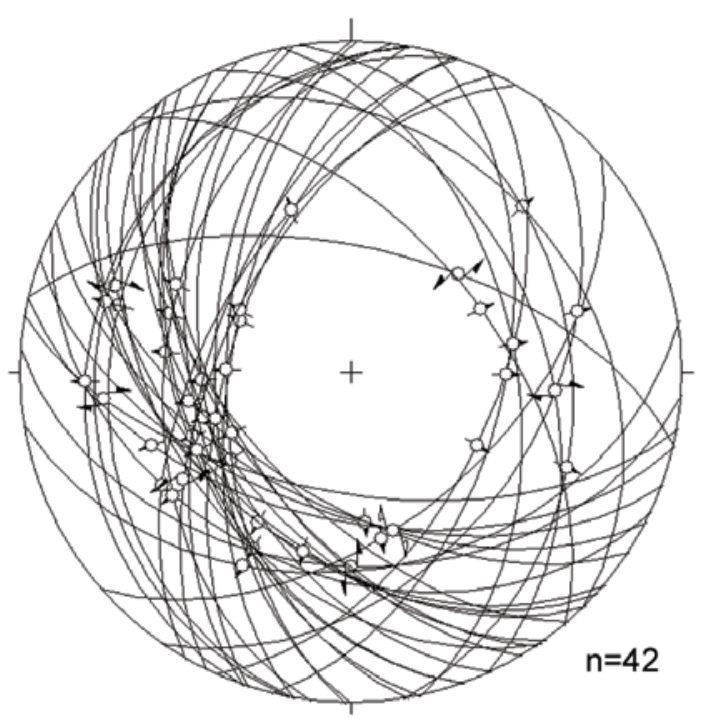

Fault planes

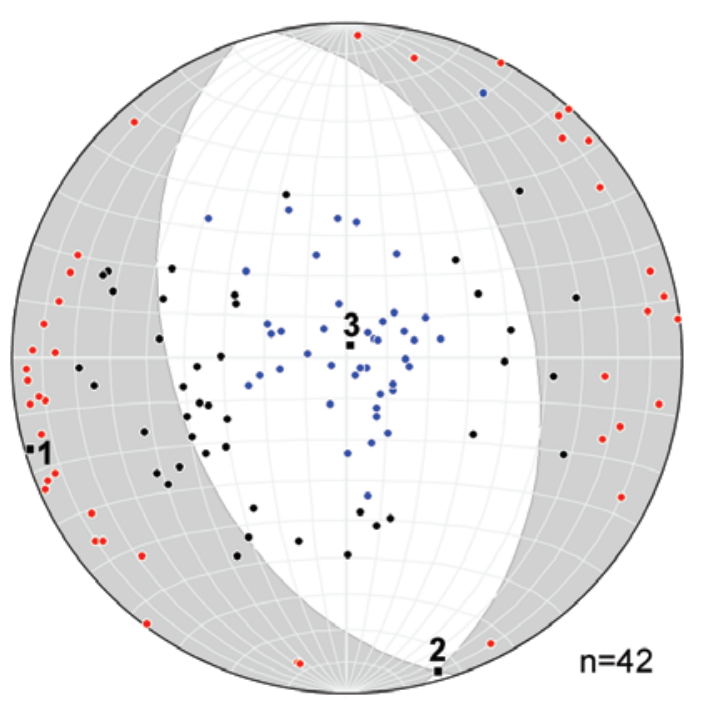

Kinematic fault plane solution

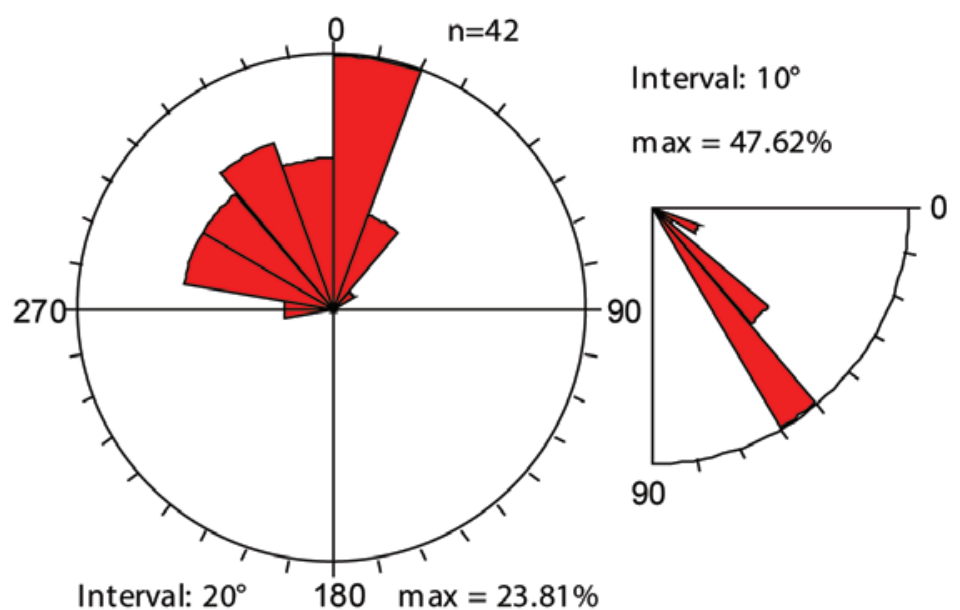

fault strike

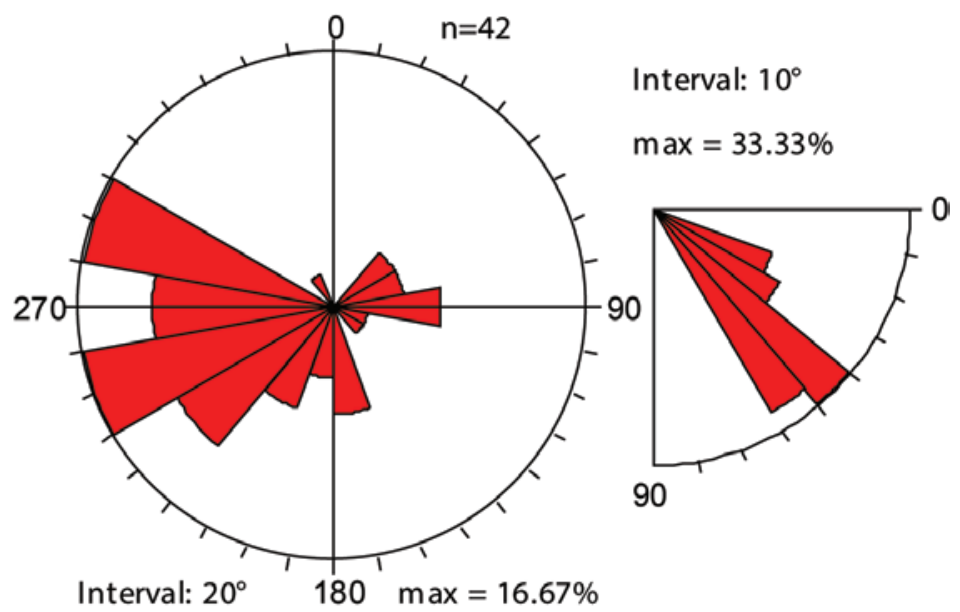

striae trend

striae plunge

----- Fault Plane Solution -----

Fault Strike Dip Trend Plunge Slip Sense

$\begin{array}{llllll}1 . & 347.0 & 43.3 & 071.2 & 43.2 & \mathrm{~N}\end{array}$

$\begin{array}{llllll}\text { 2. } & 161.2 & 46.8 & 257.0 & 46.7 & \mathrm{~N}\end{array}$

P-axis: $015.3,86.6 ; \quad$ T-axis: $254.0,01.8$

-----Linked Bingham Analysis -----

Axis Eigenvalue Trend Plunge

$\begin{array}{llll}\text { 1. } & 0.3277 & 254.0,01.8\end{array}$

$\begin{array}{llll}\text { 2. } & 0.0792 & 163.9, & 02.9\end{array}$

3. $0.4070 \quad 015.3,86.6$

Figure A3. Equal-area stereonets of fault planes and striae (upper left), rose histograms of fault strike and dip (upper right), rose histograms of striae trend and plunge (lower right) and kinematic fault-plane solutions (lower left) of subset 1, low-angle normal faultsfaults with striae rake $>45^{\circ}$ and fault dip $\leq 60^{\circ}$. Normal faults were separated by dip because geologic mapping suggested a distinct set of lower-dip faults. Kinematic fault plane solution for all low-angle normal faults indicates an average West-Southwest extension direction (axis 1). Symbology of plots are as described in figure 1. 


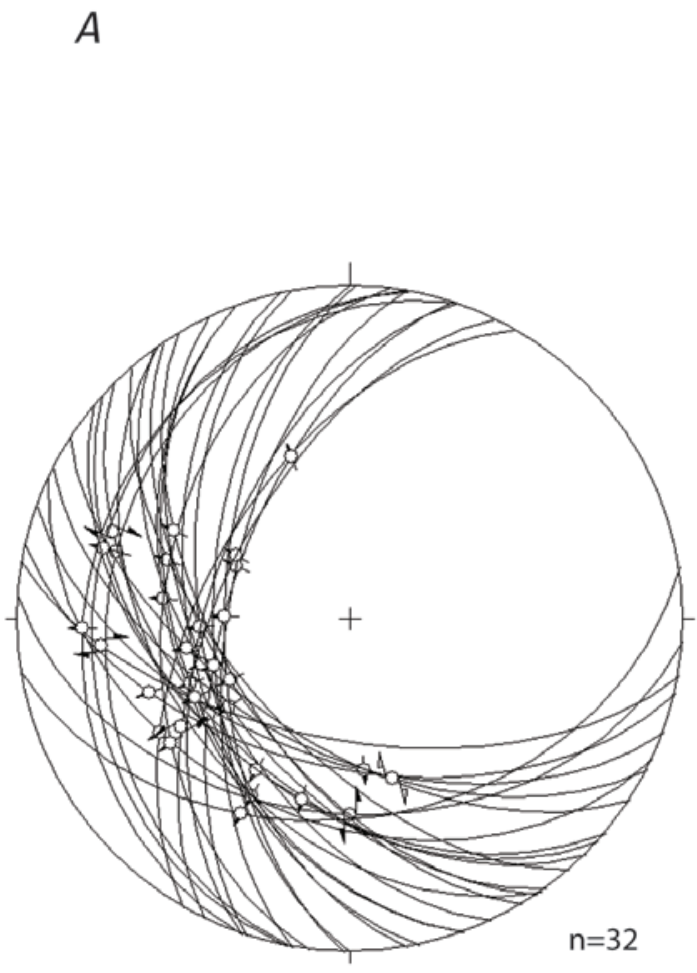

Fault planes

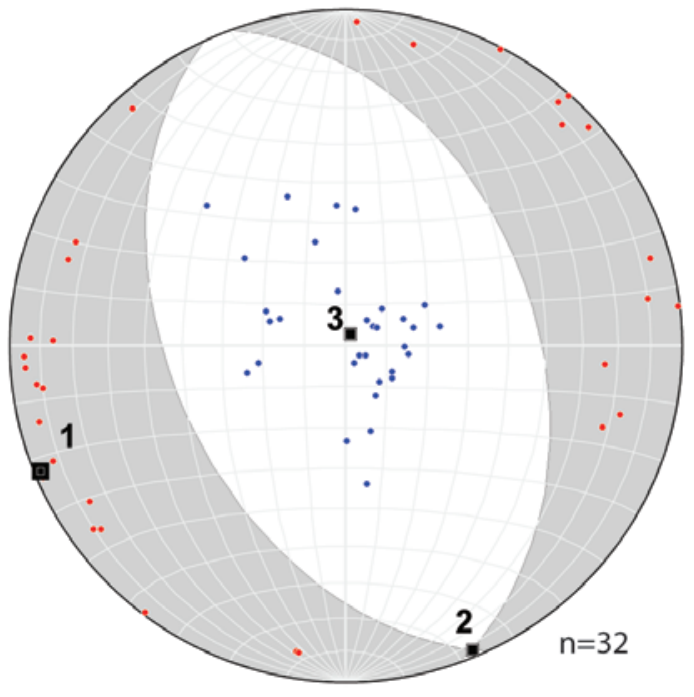

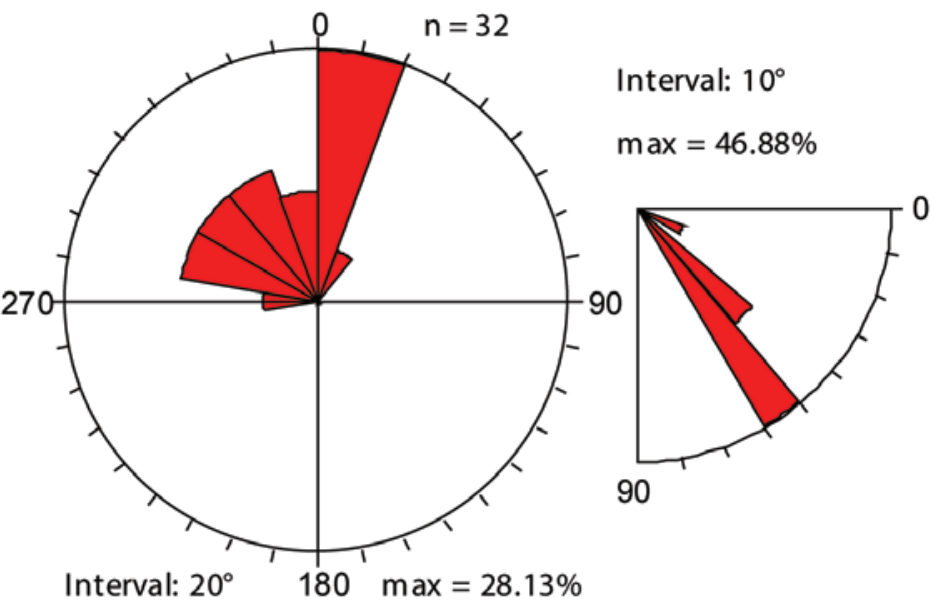

fault strike

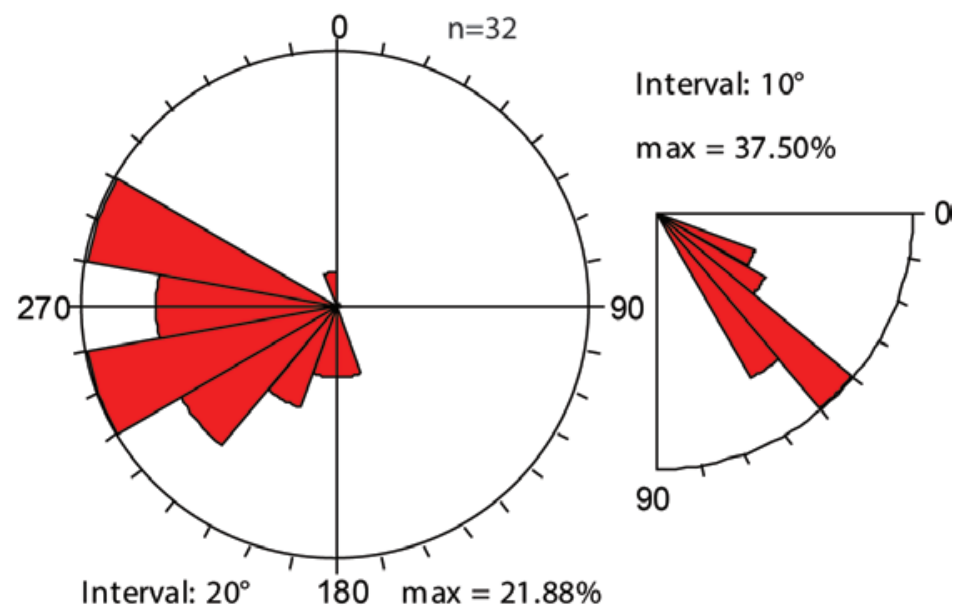

striae trend striae plunge

Fault Plane Solution

Fault Strike Dip Trend Plunge Slip Sense

$\begin{array}{llllll}\text { 1. } & 340.1 & 42.9 & 065.3 & 42.8 & \mathrm{~N}\end{array}$

$\begin{array}{llllll}2 . & 155.3 & 47.2 & 250.1 & 47.1 & \mathrm{~N}\end{array}$

P-axis: $019.2,86.8 ; \quad$ T-axis: $247.6,02.1$

-----Linked Bingham Analysis | 12/1/2011 at 12:39 PM----

Axis Eigenvalue Trend Plunge

$\begin{array}{llll}\text { 1. } & 0.3431 & 247.6, & 02.1 \\ \text { 2. } & 0.0772 & 157.5, & 02.4 \\ \text { 3. } & 0.4203 & 019.2, & 86.8\end{array}$

\section{Kinematic fault plane solution}

Figure A4. Equal-area stereonets of fault planes and striae (upper left), rose histograms of fault strike and dip (upper right) and striae trend and plunge (center right), and kinematic fault-plane solutions (lower left) of subset 1a -west- to south-dipping normal faults with dips $\angle 60^{\circ}$. A, All faults of subset 1a. B, Plots of west-dipping faults from White Rock to Bighorn Canyons. $C$, Subset 1a faults measured from Goldstrike Canyon north to Hemenway Wash. Note almost $\sim 80^{\circ}$ counterclockwise difference in strike between $B$ and $C$ and $\sim 35^{\circ}$ counterclockwise difference in extension direction (axis 1 on the kinematic fault plane solution plots). Symbols as in figure 1. 


\section{$B$}
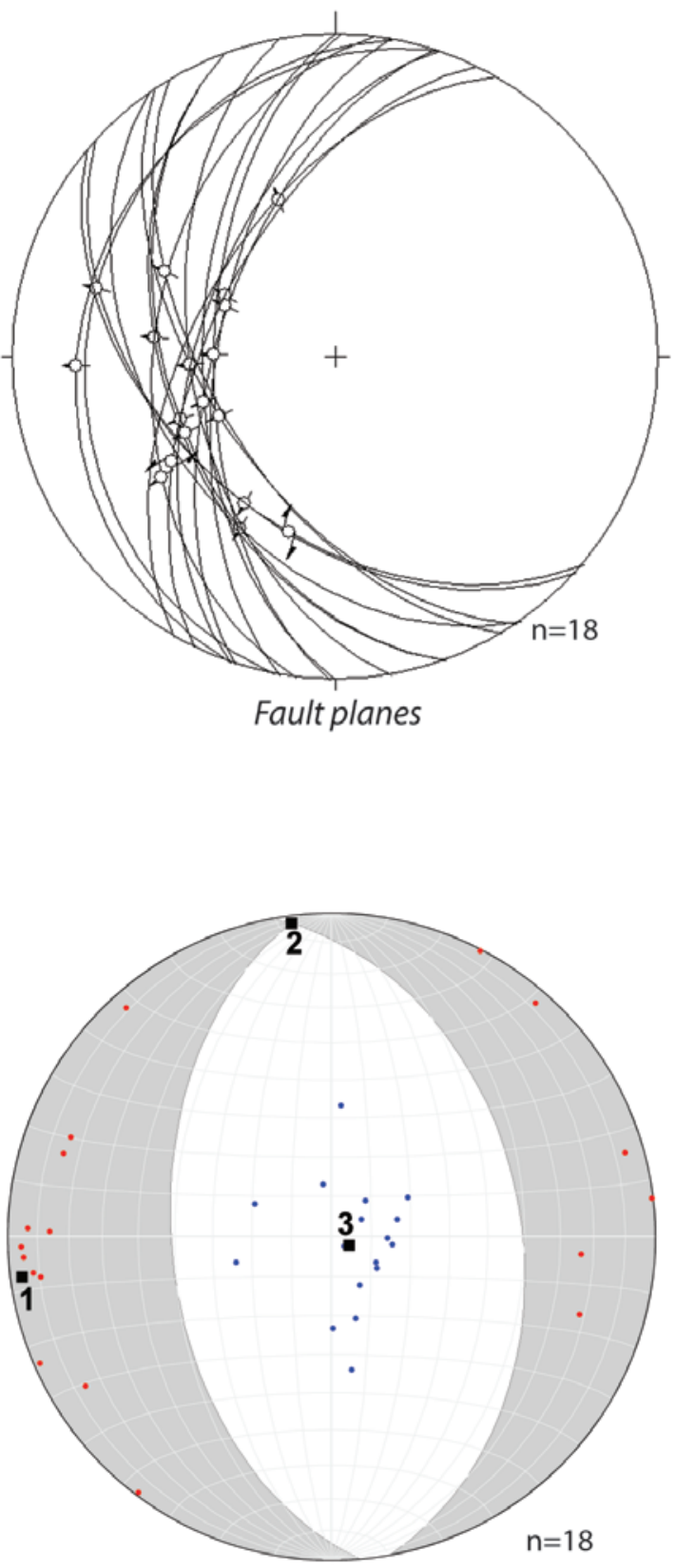

Kinematic fault plane solution

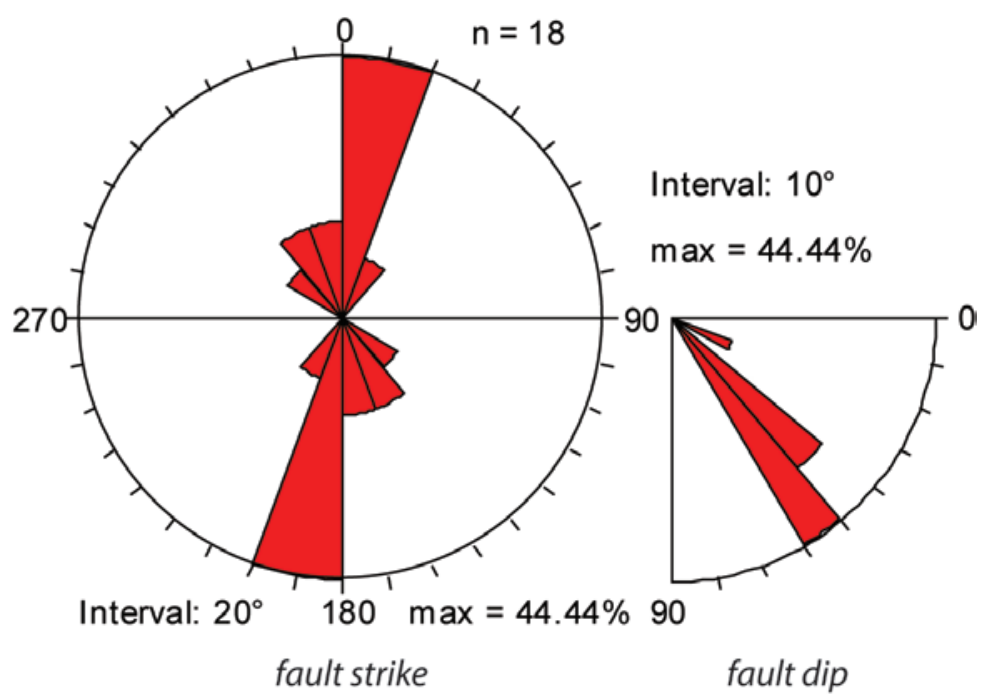

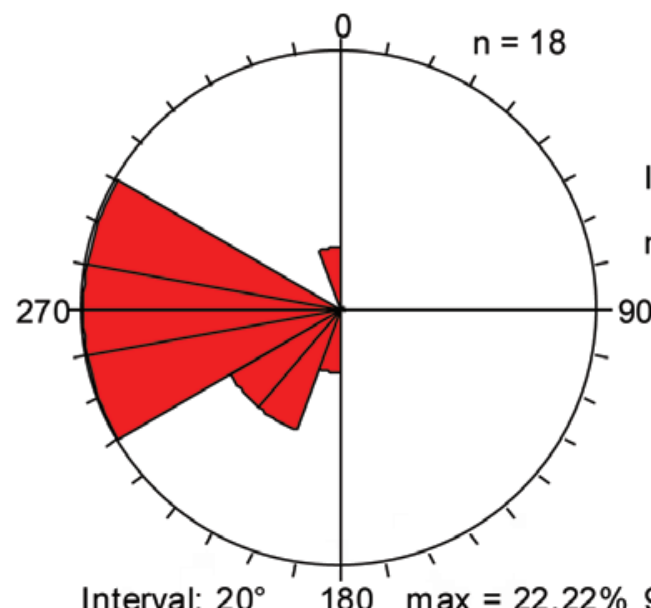

Interval: $20^{\circ} \quad 180 \max =22.22 \% 90$

striae trend

striae plunge

Fault Plane Solution

Fault Strike Dip Trend Plunge Slip Sense

$\begin{array}{llllll}\text { 1. } & 349.6 & 41.0 & 085.1 & 40.9 & \mathrm{~N}\end{array}$

$\begin{array}{llllll}\text { 2. } & 175.1 & 49.1 & 259.6 & 49.0 & \mathrm{~N}\end{array}$

P-axis: $116.4,85.1 ; \quad$ T-axis: $262.5,04.1$

-----Linked Bingham Analysis | 12/1/2011 at 12:48 PM----

Axis Eigenvalue Trend Plunge

1. $0.3780 \quad 262.5,04.1$

2. $0.0580 \quad 352.7,02.7$

3. $0.4360116 .4,85.1$

Figure A4.-Continued 


\section{C}

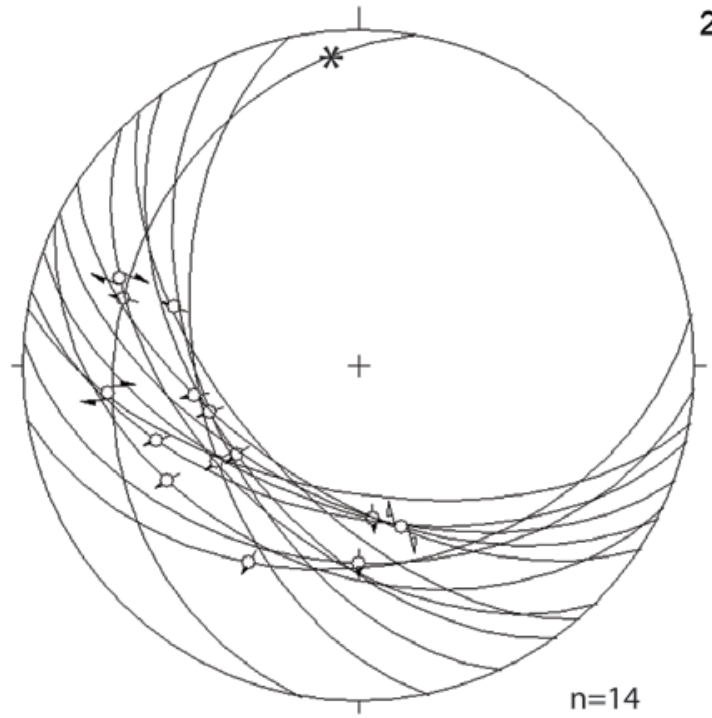

Fault planes

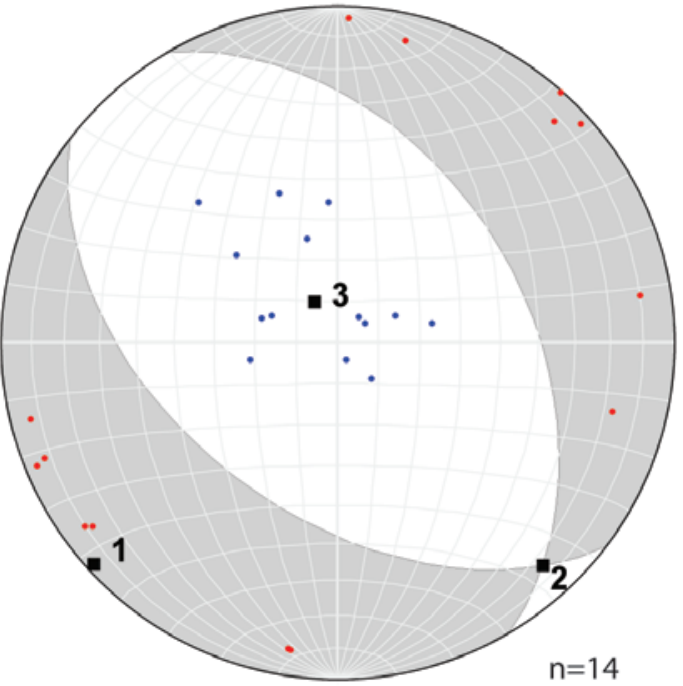

Kinematic fault plane solution

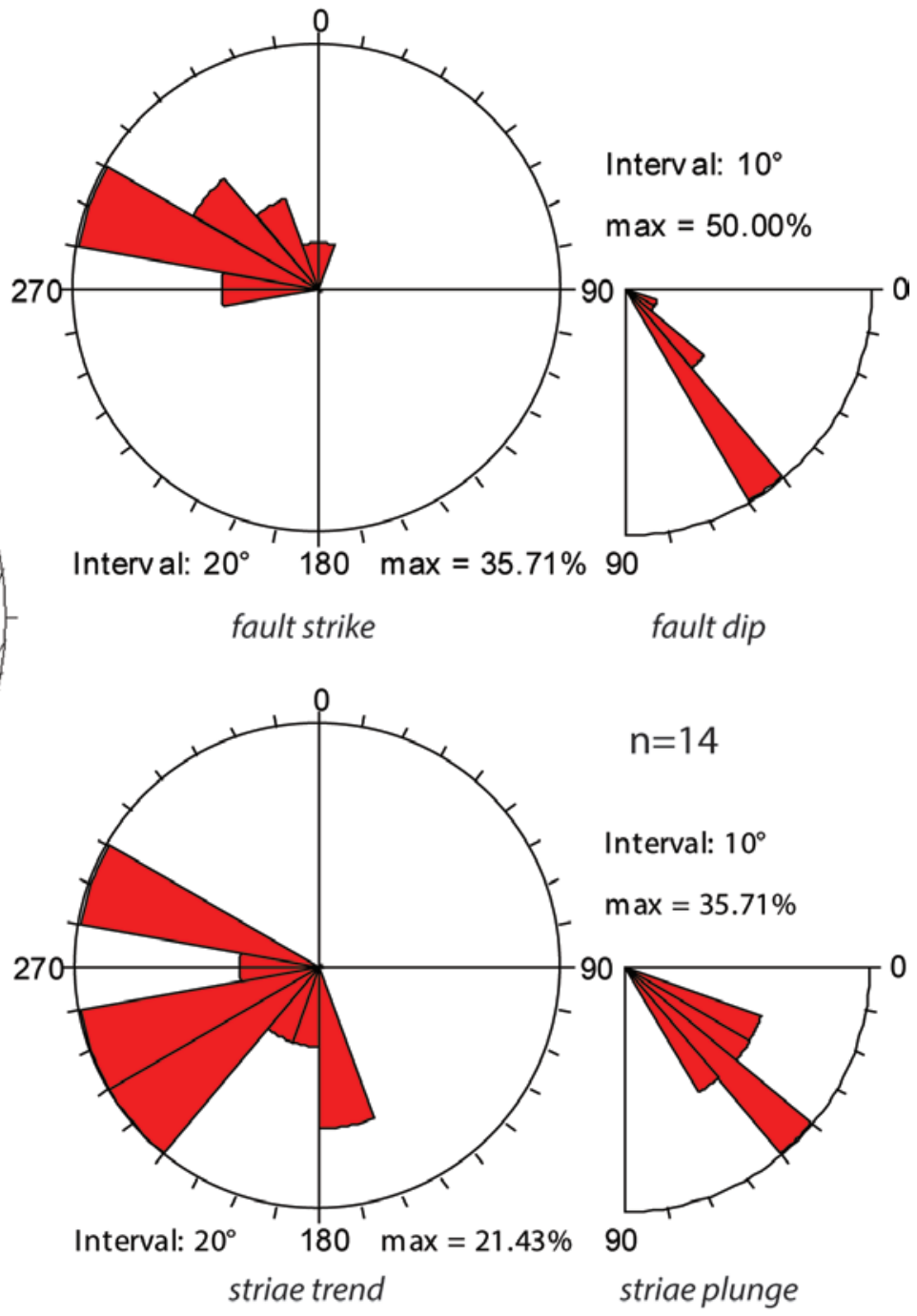

Fault Plane Solution

Fault Strike Dip Trend Plunge Slip Sense

$\begin{array}{llllll}1 . & 329.2 & 43.6 & 037.6 & 41.5 & \mathrm{~N}\end{array}$

2. $\begin{array}{lllll}127.6 & 48.5 & 239.2 & 46.4 & \mathrm{~N}\end{array}$

P-axis: 330.4, 78.7; T-axis: 227.9, 02.5

-----Linked Bingham Analysis | 12/1/2011 at 1:14 PM-----

Axis Eigenvalue Trend Plunge

1. $0.3622 \quad 227.9,02.5$

2. $0.0592137 .4,11.0$

3. $0.4214 \quad 330.4,78.7$

Figure A4.-Continued 


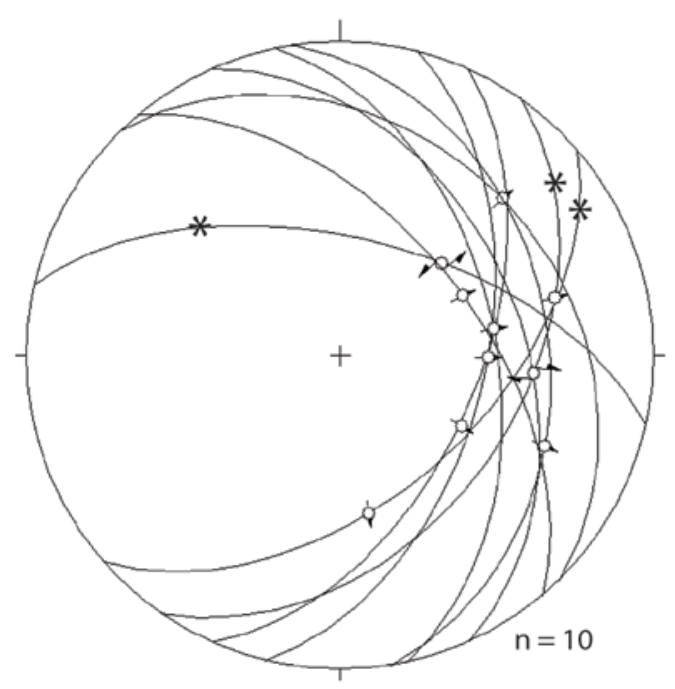

Fault planes

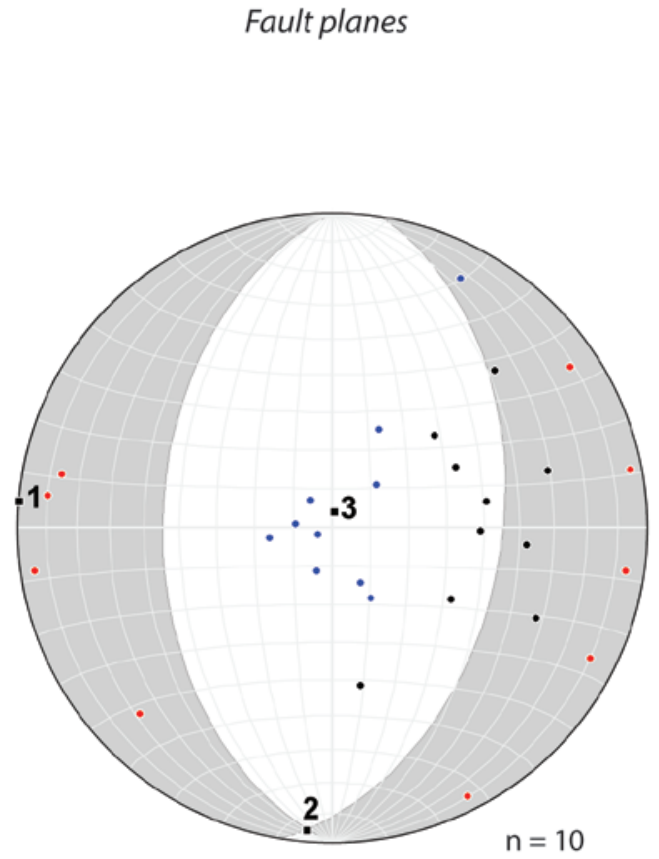

Kinematic fault plane solution

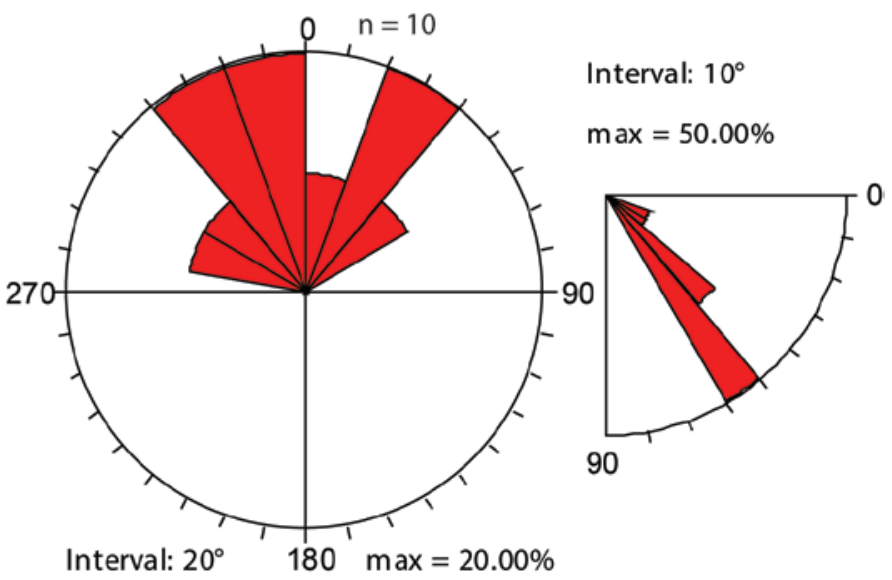

fault strike

fault dip

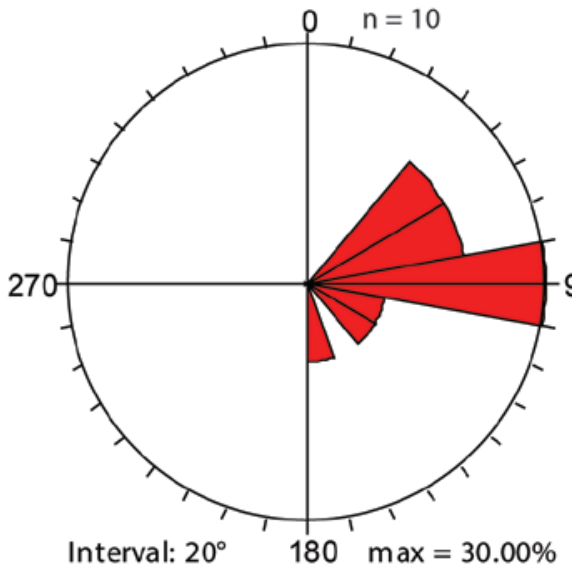

striae trend

Interval: $10^{\circ}$

$\max =40.00 \%$

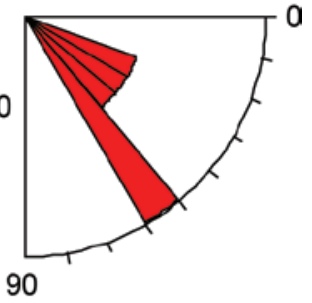

striae plunge

----- Fault Plane Solution -----

Fault Strike Dip Trend Plunge Slip Sense

$\begin{array}{llllll}1 . & 009.0 & 45.0 & 090.5 & 44.7 & \mathrm{~N}\end{array}$

2. $\begin{array}{lllll}180.5 & 45.3 & 081.0 & 45.0 \quad \mathrm{~N}\end{array}$

P-axis: 007.0, 85.8; T-axis: $274.8,00.2$

\section{-----Linked Bingham Analysis -----}

Axis Eigenvalue Trend Plunge

1. $0.3253274 .8,00.2$

2. $\quad 0.0390 \quad 184.8,04.2$

3. $0.3643 \quad 007.0,85.8$

Figure A5. Equal-area stereonets of fault planes and striae (left) and rose histograms of fault strike and dip (upper right) and striae trend and plunge (center right) of subset $1 \mathrm{~b}$-east-dipping normal faults of with dips $<60^{\circ}$. Rose diagram of strikes shows bimodal distribution of NW and NE strikes. Only three faults (with asterisks) are from the north end of the study area. East-west-striking fault is measured along the Lake Mead Fault System and is most likely rotated. Kinematic fault plane solution (lower diagram) indicates eastwest extension for subset $1 \mathrm{~b}$. Symbols as in figure 1. 


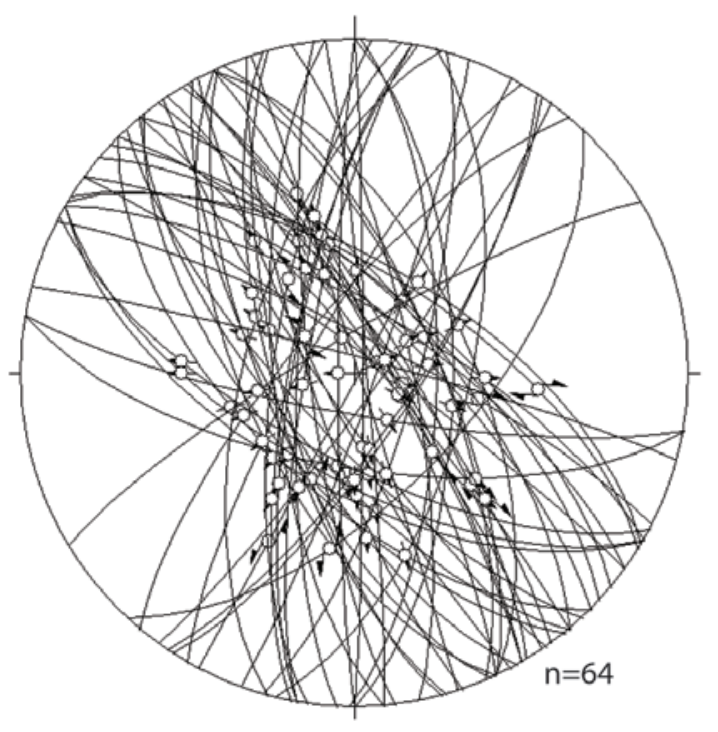

Fault planes

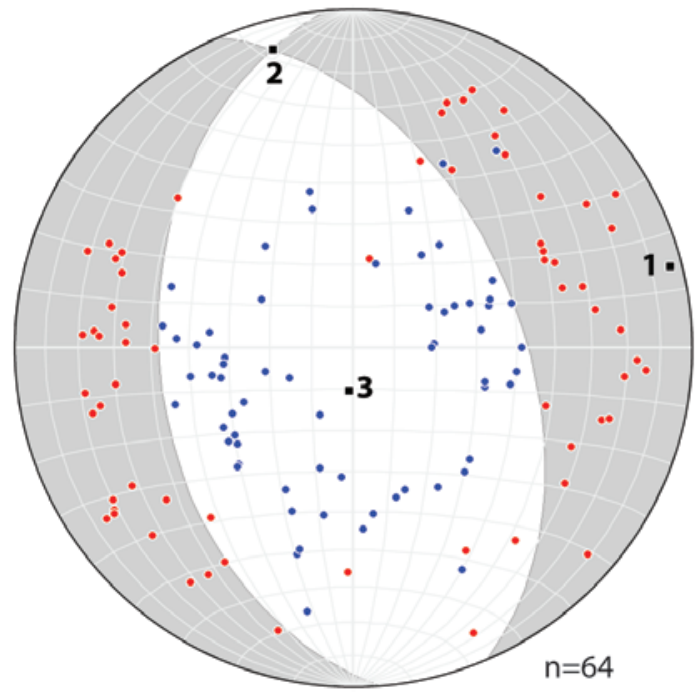

Kinematic fault plane solution
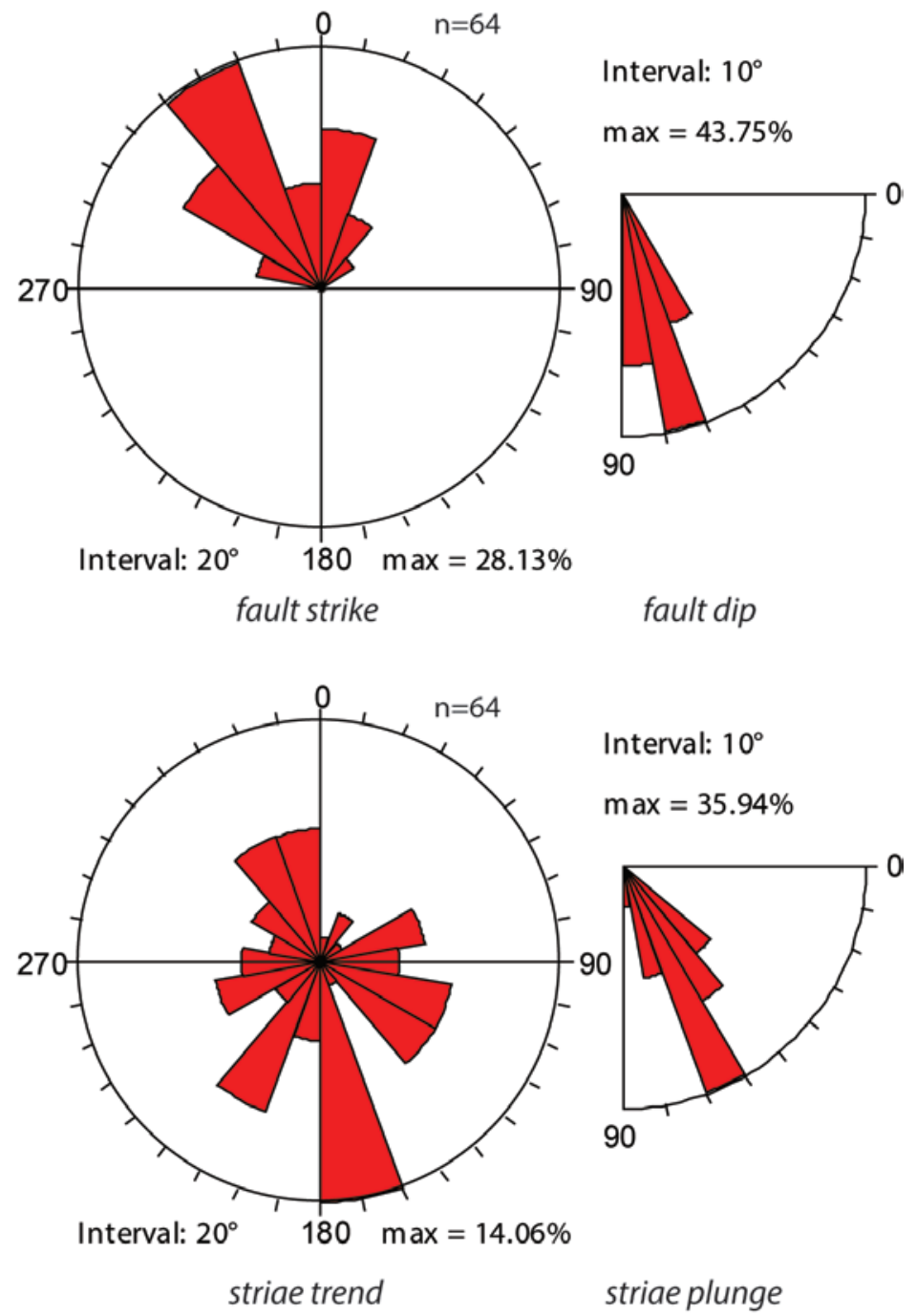

----- Fault Plane Solution -----

Fault Strike Dip Tred Plunge Slip Sense

$\begin{array}{llllll}1 . & 175.7 & 42.1 & 246.5 & 40.5 & \mathrm{~N}\end{array}$

$\begin{array}{llllll}\text { 2. } & 336.5 & 49.5 & 085.7 & 47.9 & \mathrm{~N}\end{array}$

P-axis: 186.5, 79.6; T-axis: $075.5,03.8$

-----Linked Bingham Analysis -----

Axis Eigenvalue Trend Plunge

1. $0.1768 \quad 075.5, \quad 03.8$

2. $0.0484 \quad 344.9,09.6$

3. $0.2252 \quad 186.5,79.6$

Figure A6. Equal-area stereonets of fault planes and striae (upper left), rose histograms of fault strike and dip (upper right) and striae trend and plunge (center right), and kinematic fault-plane solution (lower left) of subset 2-normal faults with dips $\geq 60$ population. Symbols as in figure 1. Extension direction (axis 1 ) is east-northeast. 
$\boldsymbol{A}$
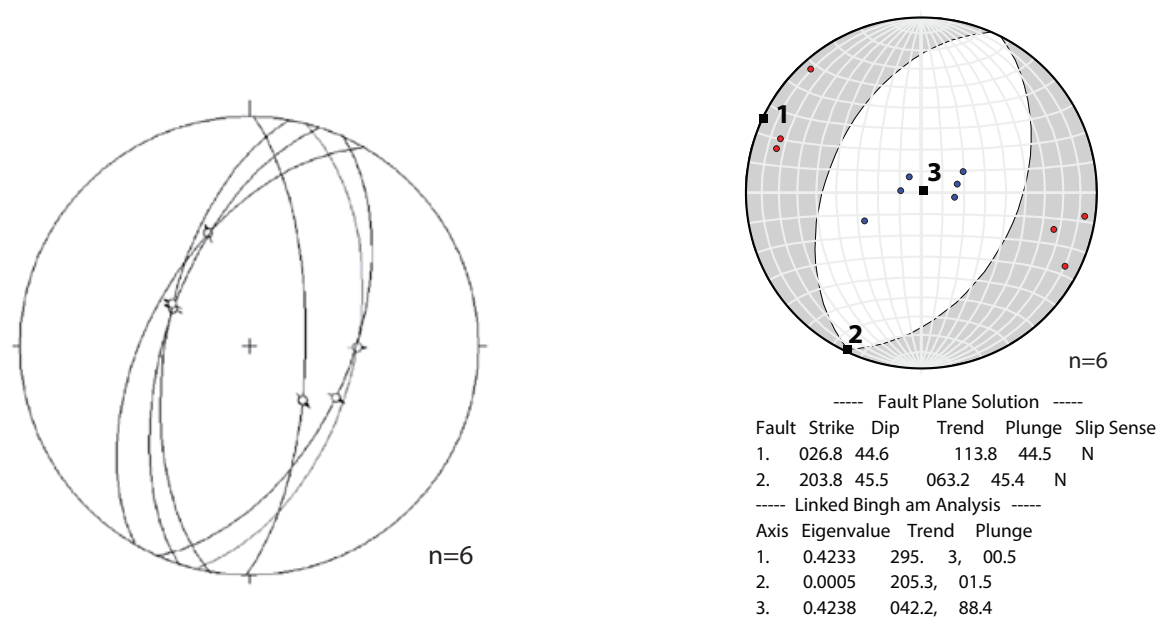

B
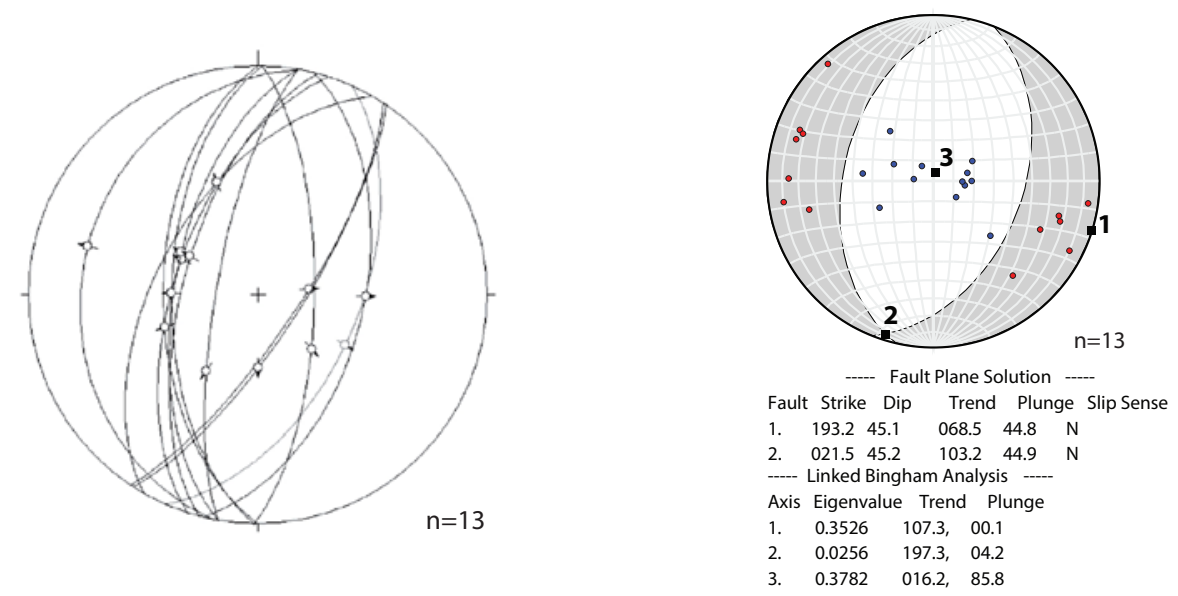

C
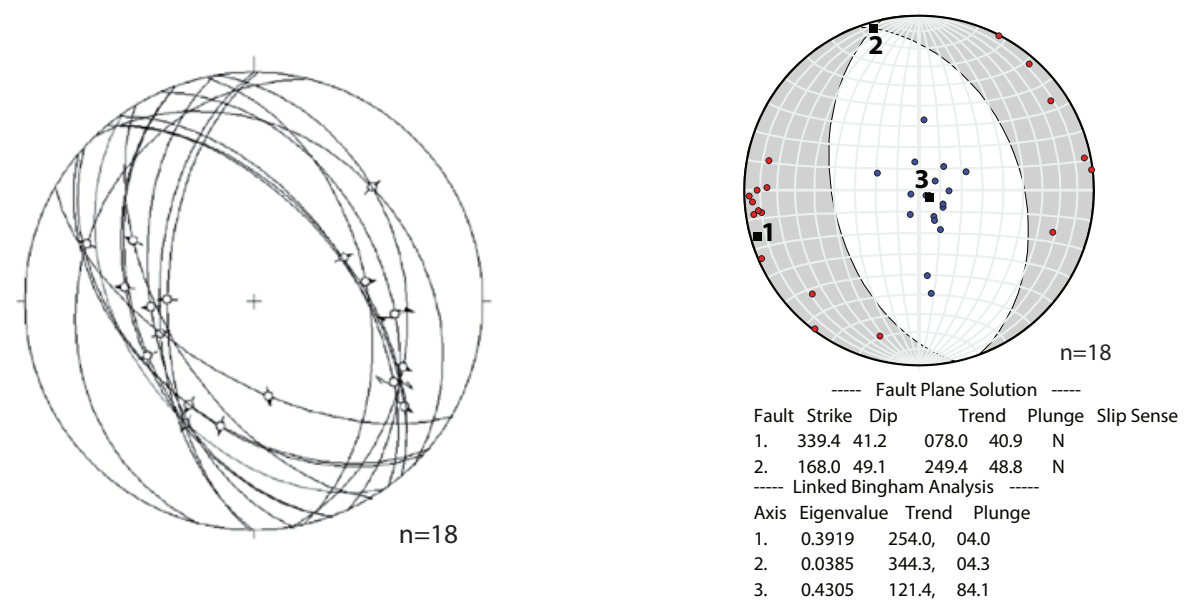

Figure A7. Equal-area steronet plots of fault planes and striae (left) and kinematic fault-plane solutions (right) of fault subsets in Arizona and White Rock (AZWR) Canyons showing difference in strikes and extension directions between inferred older and younger normal fault sets, and conjugate style of both sets. $A$, Faults from Mount Davis Volcanics within the AZWR graben. The extension direction (axis 1) is northwest. $B$, All north-northeast striking normal faults from AZWR Canyons (including those within graben) that cut both Mount Davis and Patsy Mine Volcanics. These faults are inferred to represent the younger fault set. $C$, All north-northwest striking normal faults in AZWR Canyons from subset 1-low-angle normal faults. These faults are inferred to represent the older fault set and are predominantly located in the Patsy Mine rocks. The extension direction is west-southwest, $\sim 40^{\circ}$ counterclockwise from the younger set (7A and 7B). Symbols as in figure 1. 


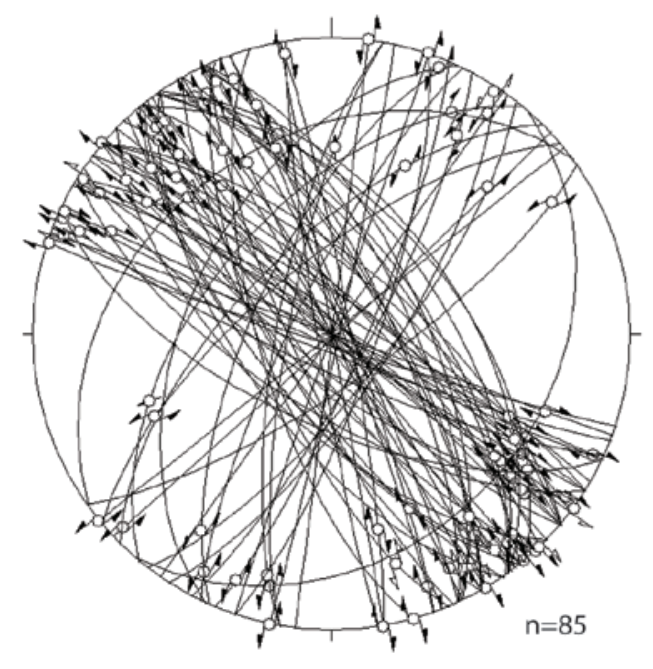

Fault planes

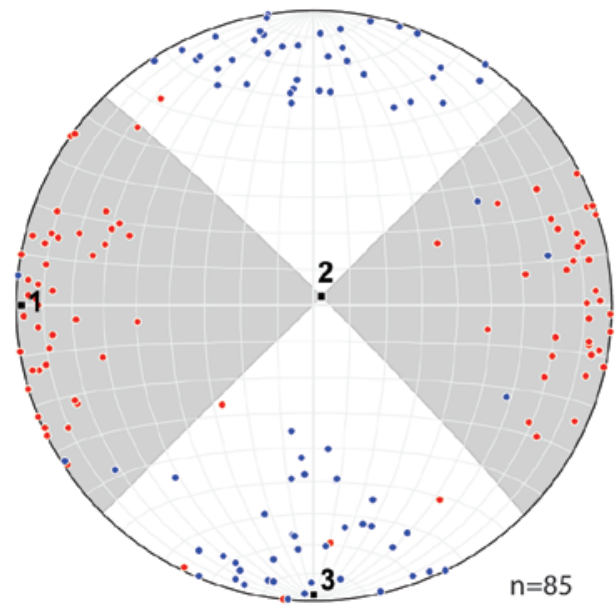

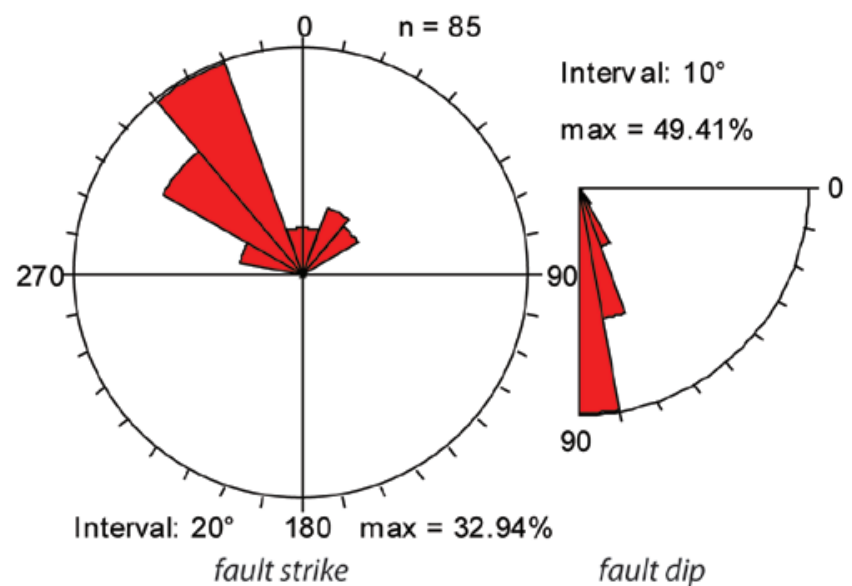

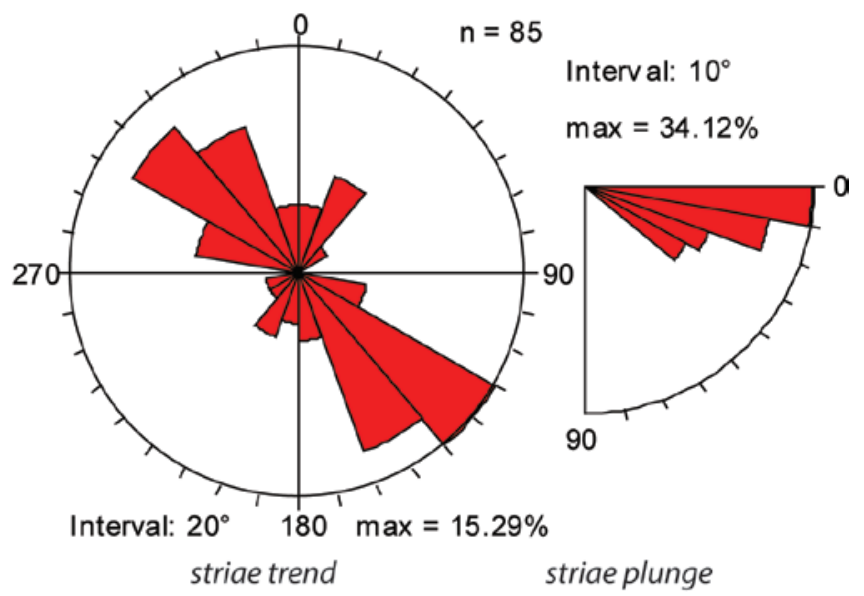

---- Fault Plane Solution ---.-

Fault Strike Dip Trend Plunge Slip Sense

$\begin{array}{llllll}1 . & 315.2 & 86.9 & 135.2 & 00.4 & \mathrm{~N}\end{array}$

$\begin{array}{llllll}\text { 2. } & 225.2 & 89.6 & 225.2 & 03.1 & \mathrm{~N}\end{array}$

P-axis: 180.1, 02.5; T-axis: 270.2, 02.0

-----Linked Bingham Analysis -----

Axis Eigenvalue Trend Plunge

$\begin{array}{llll}\text { 1. } 0.3425 & 270.2,02.0\end{array}$

2. $0.0202038 .6,86.8$

3. $0.3224 \quad 180.1,02.5$

\section{Kinematic fault plane solution}

Figure A8. Equal-area stereonets of fault planes and striae (left), rose histograms of fault strike and dip (upper right) and striae trend and plunge (center right), and kinematic fault-plane solutions (lower left) of subset 3-strike-slip faults defined as faults with rakes $\leq 45^{\circ}$. See fig. $1 \mathrm{C}$ for plots of all strike-slip faults. Faults were separated into strike subsets based on field evidence that the east-striking faults are most likely rotated along the Lake Mead Fault system, and the north-striking, right-lateral Salt Cedar Fault in the northern part of the study area is younger. $A$, Northwest and northeast-striking strike-slip faults. $B$, East-striking strike-slip faults. Kinematic fault-plane solution has poor fit to P-T axes, indicating nonhomogeneous population. $C$, North-striking faults, showing dispersion of dip and rake of faults, which combined with normal-oblique kinematic fault-plane solution, also indicates a nonhomogeneous population. The near vertical right-lateral fault measurements are from the Salt Cedar Fault sytem in and near Goldstrike Canyon. Symbols as in figure 1. 


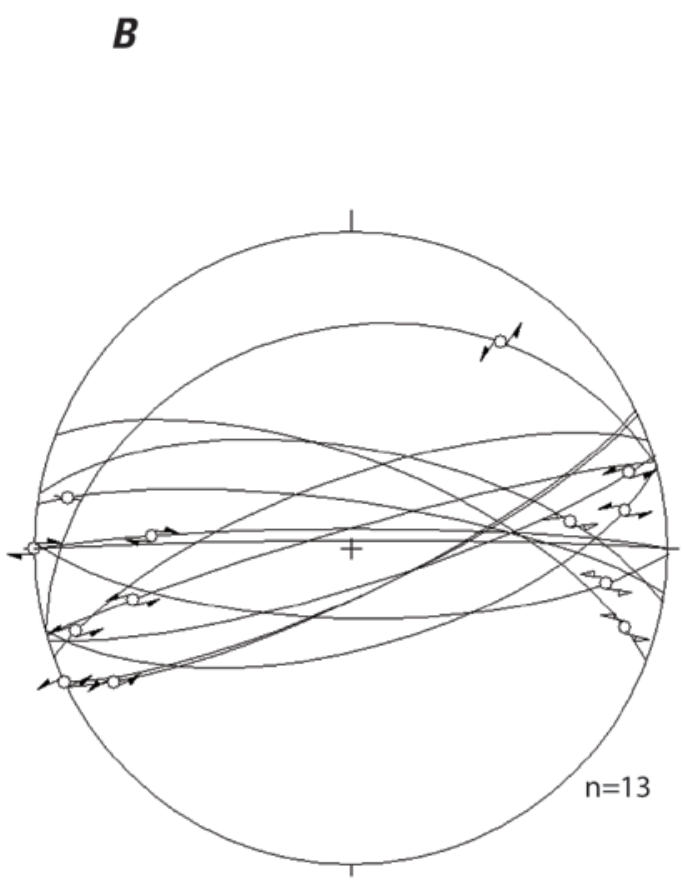

Fault planes

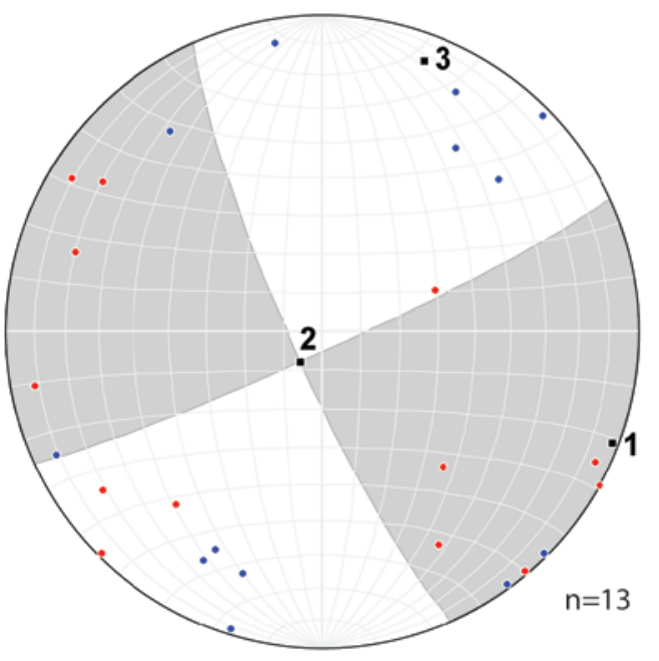

Kinematic fault plane solution

Figure A8.-Continued

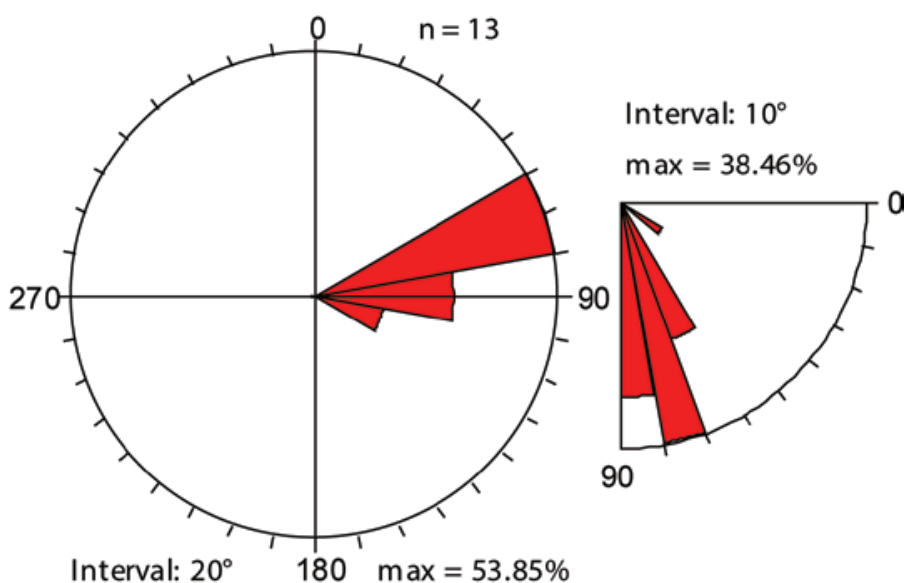

fault strike

fault dip

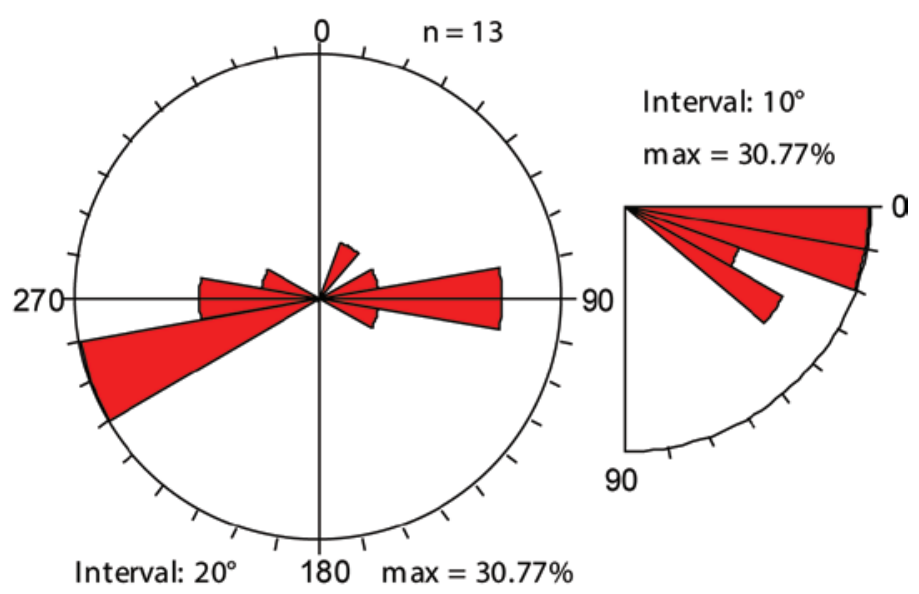

striae trend

striae plunge

----- Fault Plane Solution -----

Fault Strike Dip Trend Plunge Slip Sense

$\begin{array}{llllll}\text { 1. } & 156.1 & 81.7 & 024.6 & 04.9 & \mathrm{~N}\end{array}$

$\begin{array}{llllll}\text { 2. } & 065.4 & 85.1 & 066.1 & 08.3 & \mathrm{~N}\end{array}$

P-axis: 020.5, 09.3; T-axis: 110.9, 02.4

-----Linked Bingham Analysis |-----

Axis Eigenvalue Trend Plunge

$\begin{array}{llll}1 . & 0.1694 & 110.9, & 02.4\end{array}$

2. $0.0377 \quad 215.1,80.4$

3. $0.2070020 .5,09.3$ 
C

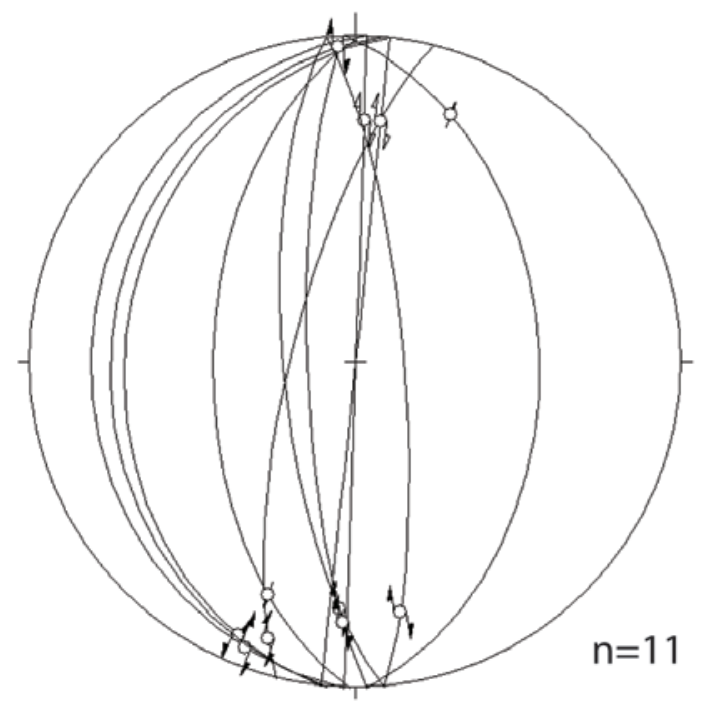

Fault planes

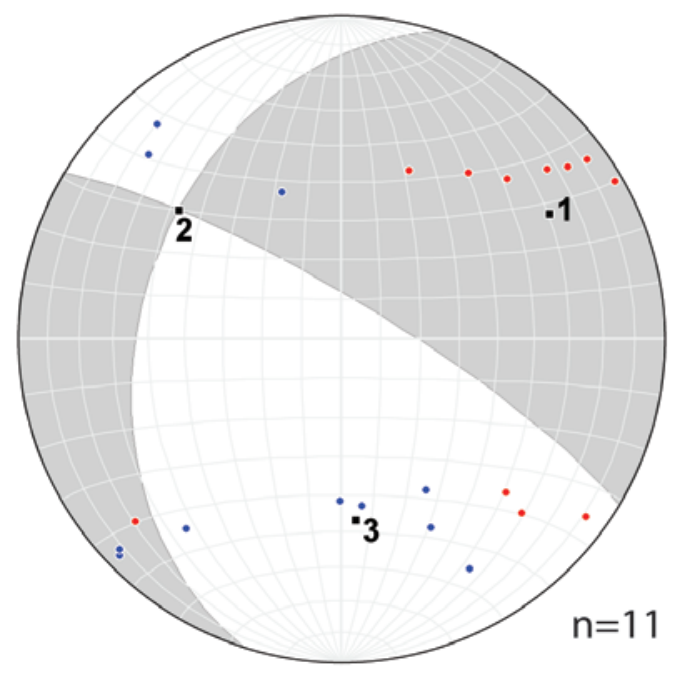

Kinematic fault plane solution

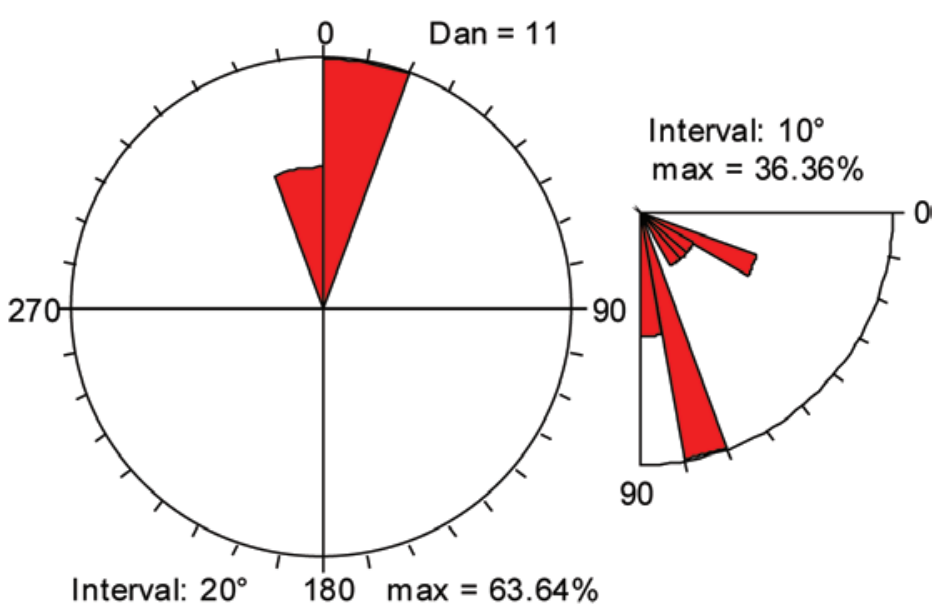

fault strike

fault dip

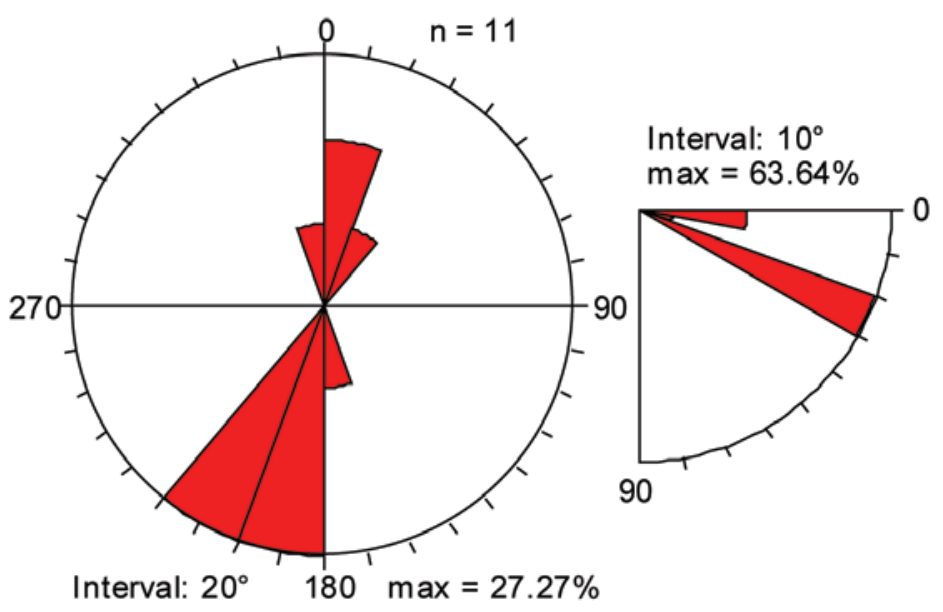

striae trend

striae plunge

---- Fault Plane Solution -----

Fault Strike Dip Trend Plunge Slip Sense

$\begin{array}{llllll}1 . & 197.6 & 37.9 & 210.9 & 10.2 & \mathrm{~N}\end{array}$

$\begin{array}{llllll}2 . & 300.9 & 79.8 & 107.6 & 52.1 & \mathrm{~N}\end{array}$

P-axis: 175.6, 43.1; T-axis: 058.8, 25.7

----Linked Bingham Analysis |----

Axis Eigenvalue Trend Plunge

1. $0.2332058 .8,25.7$

2. $0.0639308 .4,36.0$

3. $0.1693 \quad 175.6,43.1$

Figure A8.-Continued 
$\boldsymbol{A}$

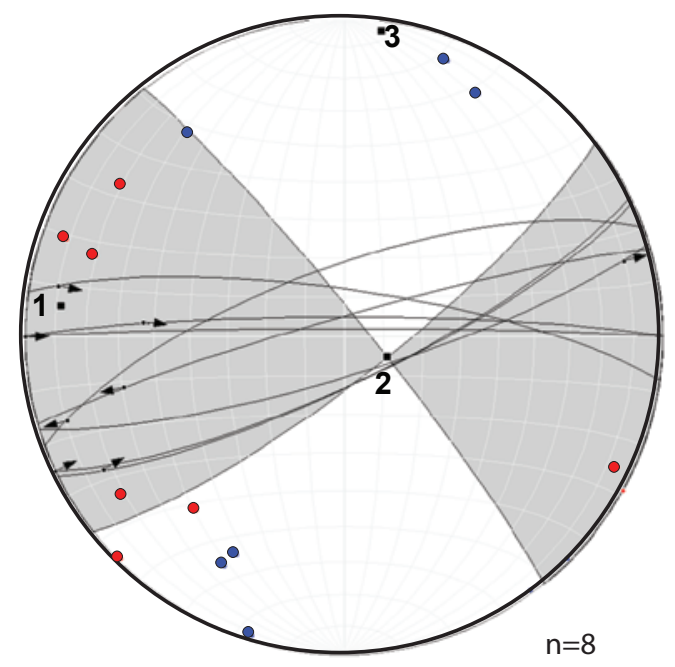

----- Fault Plane Solution

Fault Strike Dip Trend Plunge Slip Sense

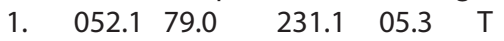

$\begin{array}{llllll}\text { 2. } & 321.1 & 84.7 & 037.9 & 11.0 & \mathrm{~N}\end{array}$

P-axis: 007.0, 04.0; T-axis: 276.2, 11.5

-----Linked Bingham Analysis

Axis Eigenvalue Trend Plunge

$\begin{array}{llll}1 . & 0.2247 & 276.2, & 11.5\end{array}$

2. $0.0063 \quad 115.7,77.8$

3. $0.2184007 .0,04.0$
B

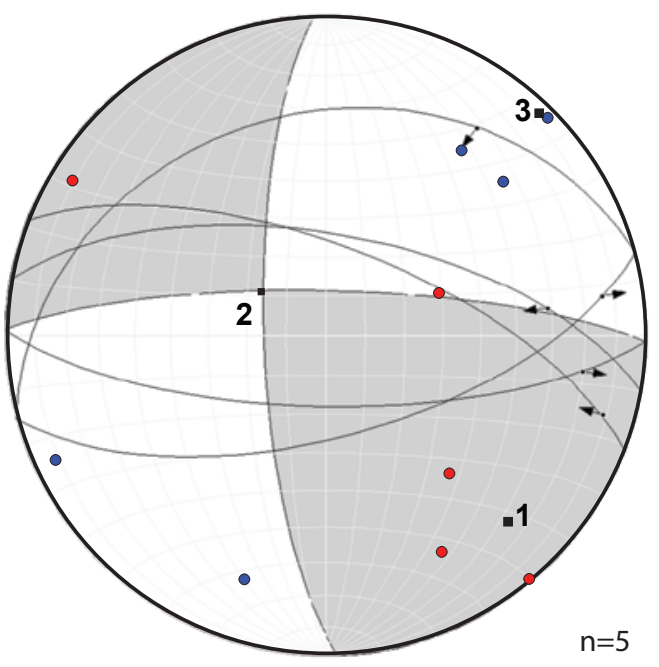

----- Fault Plane Solution

Fault Strike Dip Trend Plunge Slip Sense

1. $\quad \begin{array}{lllll}177.9 & 74.3 & 181.1 & 11.4 & \mathrm{~T}\end{array}$

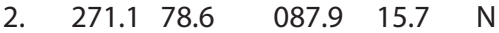

P-axis: 044.0, 02.9; T-axis: 135.1, 19.3

-----Linked Bingham Analysis

Axis Eigenvalue Trend Plunge

$\begin{array}{llll}1 . & 0.3259 & 135.1, & 19.3\end{array}$

2. $0.0498 \quad 305.7,70.5$

3. $0.3756044 .0,02.9$

Figure A9. Kinematic fault-plane solutions for $(A)$ east-west strike-slip faults in the northern part of study area. $B$, East-west strike-slip faults in Arizona and White Rock Canyons. Symbols as in figure 1. 
Menlo Park Publishing Service Center, California

Manuscript approved for publication January 28, 2014

Edited by John L. Buursma and Claire Landowski

Design and layout by Cory Hurd 
